Rhode Island College

Digital Commons @ RIC

Master's Theses, Dissertations, Graduate

Master's Theses, Dissertations, Graduate Research and Major Papers Overview

Research and Major Papers

4-9-2021

\title{
\#MeToo Movement: A Sociological Analysis of Media Representations
}

Lindsay Tahan

Follow this and additional works at: https://digitalcommons.ric.edu/etd

Part of the Social Justice Commons

\section{Recommended Citation}

Tahan, Lindsay, "\#MeToo Movement: A Sociological Analysis of Media Representations" (2021). Master's Theses, Dissertations, Graduate Research and Major Papers Overview. 339.

https://digitalcommons.ric.edu/etd/339

This Thesis is brought to you for free and open access by the Master's Theses, Dissertations, Graduate Research and Major Papers at Digital Commons @ RIC. It has been accepted for inclusion in Master's Theses, Dissertations, Graduate Research and Major Papers Overview by an authorized administrator of Digital Commons @ RIC. For more information, please contact digitalcommons@ric.edu. 


\title{
\#MeToo Movement: A Sociological Analysis of Media Representations
}

\author{
Lindsay Tahan \\ Rhode Island College
}

Word Count: 30048

Lindsay Tahan can be reached at lindsaytahan24@gmail.com. Lindsay would like to express her appreciation for mentorship from Dr. Tanni Chaudhuri and Rhode Island College. 


\section{TABLE OF CONTENTS}

I. ABSTRACT

II. INTRODUCTION

III. REVIEW OF LITERATURE

A. THEORIES

1. FEMINIST THEORY

2. MASS MEDIA THEORETICAL PERSPECTIVE

B. HISTORY OF SEXUAL ASSAULT

C. MAL E PERPETRATORS

D. FEMALE PERPETRATORS

E. SURVIVORS

F. \#METOO IN ITS CURRENT CONTEXT

G. LEGAL IMPACTS

H. BACKLASH

IV. QUANTITATIVE HYPOTHESES

V. METHODS

A. QUANTITATIVE CODING

B. QUANTITATIVE VARIABLES

C. QUALITATIVE CODING

D. QUANTITATIVE FINDINGS

VI. DISCUSSION

VII. LIMITATIONS

VIII. RECOMMENDATIONS

IX. REFERENCES

X. APPENDICES 


\begin{abstract}
The Me Too or \#MeToo movement has come under the spotlight in recent years since more survivors/victims are now speaking out against their abuser. These survivors/victims repressed their abuse for years, ashamed to speak out in fear that they would not be believed or face extreme scrutiny and humiliation. Survivors/victims are now coming together to seek justice and to reform the judicial system and how they handle sexual abuse and violence cases. This movement has become more prominent now than it was when it first was formed in 2006 by Tarana Burke and reintroduced by Alyssa Milano using Twitter in 2017. The movement challenges everyday lifestyles and workplace environments to consider what behaviors constitute as appropriate. Companies and businesses are now implementing compliance workplace harassment training to avoid such incidences of sexual abuse and violence.
\end{abstract}




\section{INTRODUCTION}

The Me Too or \#MeToo movement was first created by Tarana Burke in 2006, which was then reintroduced by Alyssa Milano on Twitter, which quickly developed into a nationwide movement. This movement was created to make changes towards equality. This movement does not aim to target specific individuals but to help those survivors/victims have a voice to speak out against their abuser knowing they are not alone. The movement challenges the judicial system to make changes to the laws and policies that acknowledge sexual abuse and violence and to seek the due process and justice individuals deserve.

The Me Too or \#MeToo movement was originally formed on Myspace by Tarana Burke in 2006. She created the movement when she learned that a young girl was raped by her mother's boyfriend. Soon to follow, the actress, Alyssa Milano, took to Twitter on October of 2017 and posted a tweet saying, "Women who have been sexually harassed or assaulted, write \#MeToo." The \#MeToo hashtag went viral in the midst of the accusations against Harvey Weinstein. It is a grassroots movement against sexual harassment across regions, high-profile celebrity cases that attracted the public eye, the use of social media as a platform to be heard, the \#MeToo movement allows the victims to speak publicly about their abuse from a safe distance from the abuser or harasser (Gibson et al. 2019).

The \#MeToo movement also gave rise when President Donald Trump admitted publicly that he engaged in sexual harassment and Barack Obama's Title IX enhancements that spread awareness about sexual assaults on college and university campuses, and Bill Cosby's mistrial in 2017 who has since been convicted of sexual assault in 2018 (Gibson et al. 2019). The Me Too movement's mission is to connect survivors of sexual assault to the resources the individuals need to heal and to promote empowerment through empathy (Jaffe 2018). The movement's goal 
is to help the survivors/victims feel comfortable and unashamed to speak up about the violence that has been caused. Tarana Burke, the founder of the Me Too movement said that the outcome of the Harvey Weinstein case should be viewed as power to keep survivors and allies motivated for change. Since transitioning to the third year since the \#MeToo movement went viral, it is important to think about making strategic plans and moves that are beyond individual takedowns (Kantor 2020). The movement is pushing towards sex education in schools that emphasize consent, longer statutes of limitations and filing deadlines for lawsuits, more expansive legal definitions of sexual harassment, stronger federal laws to protect more workers and other changes.

Before and after the \#MeToo movement allegations and accusations not only consisted of male perpetrators, but female perpetrators as well, as will be mentioned later on in the research paper. The \#MeToo movement has sparked some legal policies to change as well as behaviors in the workplace and outside of the workplace. It is important to recognize that some behaviors need not go unnoticed and that behaviors taken out of context can jeopardize an individual's reputation and can result in employment termination or lawsuits.

In the following sections of the research paper, a review of literature will be conducted that first explores the theoretical background of the \#\#MeToo movement; both from a sociological standpoint as well as a mass media perspective. Additionally, a history of sexual assault will be examined, followed by a brief discussion of cases with men and women as perpetrators and a few select survivors/victims. The literature review will also highlight a few quantitative hypotheses that will be tested throughout the research.

This research takes on a mixed methods approach, which means that the researcher will analyze both quantitative and qualitative data within the same study. This mixed methods 
approach will examine newspaper articles that will address the research questions. In the subsequent section the methods of data analysis will be discussed, along with the findings from qualitative and quantitative analyses. Finally, the findings will be examined from practical and theoretical perspectives. Throughout the research process, the following questions will be asked: Research Question Quantitative: What determines the portrayal of the \#MeToo movement in the media in newspaper articles?

Research Question Qualitative: How is the \#MeToo movement portrayed in the media in newspaper articles?

The researcher will closely analyze some factors that impact news coverage revolving around sexual victimization and the \#MeToo movement and the representation of the \#MeToo movement in newspaper articles. Female and male authors will be closely examined to see how they report coverage regarding sexual abuse and the movement and display any significant changes regarding how each story is reported by each gender by the tone and treatment. 


\section{REVIEW OF LITERATURE}

\section{THEORIES}

\section{Feminist Theory}

Feminist theory or commonly known as the women's movement, focuses on investigating gender inequality. Feminist theory challenges the systematic inequalities that women face on a daily basis. Feminism works towards equality, not female superiority. Some themes feminist theory evaluates include discrimination, patriarchy, oppression, stereotyping, objectification, art history and contemporary art, nationality, race, economic status, sexual abuse, equal pay, domestic violence, reproductive rights, and much more.

The feminism movement has focused on a wide range of different perspectives. Feminist activists have campaigned for women's legal rights (rights of contract, property rights, voting rights); for women's right to bodily integrity free from interference and autonomy, for abortion rights, and for reproductive rights (including access to contraception and quality prenatal care); for protection of women and girls from domestic violence, sexual harassment and rape; for workplace rights (maternity leave, and equal pay); against misogyny; and against other genderspecific discrimination against women (History and Theory of Feminism 2020). Throughout history there have been many waves. The first wave refers to the women's suffrage movements of the nineteenth and early twentieth centuries (concerned with women's right to vote). The second wave refers to the ideas and actions surrounding the women's liberation movement which began in the 1960s. The second wave movement lobbied for legal and social rights for women. The third and final wave refers to the continuation and reaction of the failures of the waves beginning in the 1990s (History and Theory of Feminism 2020). 
There are many types of feminist perspectives that have different standpoints (Tong 2001). For example, liberal feminists indicate that women's oppression is rooted in social, political and legal constraints. While radical feminists indicate that the patriarchal system must be removed completely, and women should be free to practice sexual and reproductive freedom. Radical cultural feminists advise women to remove themselves from the institution of compulsory heterosexuality. Marxist-socialist feminists allege that it is impossible for anyone especially women to achieve true freedom in a class-based society. Multicultural feminists explain how this "sameness" approach could be used as a weapon of oppression rather than liberation. Postmodern feminists challenge Western dualistic thinking. Global feminists stress the universal concern of women worldwide. Ecofeminists focus on the connection between humans and the nonhuman world. Feminist theory has affected all structures, systems, and disciplines, challenging ontological and epistemological assumptions about human nature and "maleness" and "femaleness" (Tong 2001).

Liberal feminism would be more applicable to the \#MeToo movement because this type of feminism desires equality in the sense of sameness of attainment and treatment. This type of feminism states we deserve to be equal, if we are the same. Equality and androgyny are disputed terms (Evans 1995). Equality means that there should be some sort of equality of opportunity for the sexes when it comes to the procedural sense, no pro-male bias. Androgyny does not just mean the ignoring of differences, but an absence of differences relevant to full participation in the structures that exist now (Evans 1995). The feminist theory and the feminism movement are working towards treating males and females equally. Throughout this \#MeToo movement, women are fighting for justice in regards to sexual abuse and demand to be heard and for the perpetrators to be punished instead of given a slap on the wrist and an excuse of, "Men will be 
men," or "Boys will be boys." This is just not enough anymore for these activists. They want their voices to be heard and for more victims to come forth and grow the courage to do so. Their motive is to put an end to abuse and excuses and to take some serious action so that this abuse stops indefinitely. The movement challenges the judicial system to make systematic changes in order to bring proper justice.

There are concerns that the \#MeToo Movement has become silly (Donegan 2018). Selfproclaimed feminists such as Daphne Merkin and Bari Weiss in The New York Times, Katie Roiphe in Harper's, Germaine Greer in the Sydney Morning Herald and 100 French women in Le Monde complained that many of the allegations and incidents of sexual harassment were too minor to warrant criticism. Their argument was that because there was such a wide spectrum of sexual misbehavior that the \#MeToo Movement lost its sense of meaning. Those women who complained about harassment and assaults, "perceive themselves to be as frail as Victorian housewives," said Merkin (Donegan 2018). This logic warranted that women could solve the problem of sexual harassment and assault with good humor, patience and a high tolerance for pain.

Older feminists over forty-years-old were considered sinisterly complicit, laughably outdated, or just too scared of overstepping (Donegan 2018). Younger women were considered righteously passionate, naively idealistic, or out for blood. A generational divide came from the feminist opponents and supporters of the \#MeToo movement themselves. In Harper's, Roiphe described the \#MeToo Movement as "Twitter feminism," giving the impression that only narcissistic, social media obsessed millennials want a reckoning over sexual assault (Donegan 2018). The claim about the anti-\#MeToo feminists is that the movement does not treat individual women as moral individuals with the ability to say no, to enjoy and pursue sex, and to do wrong. 
From this perspective, women who come forward about their experiences of harassment or assault should often be given more responsibility for those experiences than the rhetoric of \#MeToo assigns them. This feminist standpoint assumes that individual women have the power to make choices to diminish the negative impact of sexism, and to endure any sexist unpleasantness that can't be avoided - if only they have the grit to handle it.

By saying "me too," an individual makes themselves a part of a broader group and chooses to stand with others who have been harassed, assaulted, or raped. This solidarity is powerful. It is still rare to see such a large group of women identifying their suffering as women's suffering, claiming that they have all been harmed by the same forces of sexism, and together demanding that those forces be defeated (Donegan 2018). In this light, the diversity and breadth of the \#MeToo Movement is not a weakness, but a strength. If so many women, with so many different kinds of lives, have experienced the same sexist behavior from men, then it becomes easier to believe that the problem goes beyond individuals and instead relates to wider cultural forces.

\section{MASS MEDIA THEORETICAL PERSPECTIVES}

The mass media theory explains how media is portrayed to the audience and how the audience interprets the media's messages. Since the \#MeToo movement became a viral sensation, there has been an overload of media reports of survivors/victims stories of sexual abuse and their accusations. Many celebrities, television moguls, political figures and more wellrenown individuals have been accused of sexual abuse and the media reports each story differently, which leaves it up to the audience to determine their own beliefs and opinions about the situation. Media outlets try not to express bias throughout their stories, but it can sometimes 
be difficult not to express opinions on the matter. Media reports try to educate the public on the best news stories at that particular time that will quickly attract a larger audience.

Mass media theory combines an overview of mass communication with a discussion of theoretical issues and the role the media plays within that context (Naveed 2019). This theory communicates directly to the mass audience without messages being riddled by opinions. There are a number of tunnels in the communication flow from a source projecting to a larger audience. The most common types of media platforms include: newspaper, radio, magazines, the Internet, and television. Some types of influences the mass media may provide include: public opinion, education, popular culture, and the depiction of society.

\section{Agenda Setting Theory}

One mass media theory that connects with the \#MeToo movement and sexual abuse reports throughout the media, especially newspaper reports would be agenda setting theory. This theory suggests that there are three related agendas: media agenda, public agenda, and policy agenda. This theory assumes that with the passage of time, media agenda becomes the public agenda and they are intertwined with each other. Framing theory and agenda theory are closely connected with the agenda setting framework. According to agenda setting theory, the influence of the media can affect the presentation of the reports and issues made in the news that affects the public's viewpoint (McCombs and Shaw 2011). News reports form a story that when it is presented it can portray importance and attention seeking than other news in which the audience will perceive the story as more significant. Agenda setting theory can be used in political advertisements, campaigns, business news, public relations, and more. The media determines which type of news comes first and how individuals perceive that media and how much 
influence that media story will have on the audience. Agenda setting serves as a cognitive process known as "accessibility" (McCombs and Shaw 2011). The media provides the information to the audience which can be described as food for thought per say, which portrays the major issues happening in society and ultimately how it reflects individuals' minds.

There are two levels of agenda setting theory (McCombs and Shaw 2011). The first level is used by the researchers who study and use the media to find out its objectives and influences that the media portrays on individuals and the provoking thoughts the individuals might have from watching the media and the information given throughout. The second level is when the media focuses its attention on how individuals should think about the nature of the issues. As a result, sensationalize of these news reports may bring the interest of the audience. The media wants to grab the attention and implant thoughts in individuals minds about the issues the media portrays, which explains why the media turns certain issues viral.

\section{Gatekeeping Theory}

Gatekeeping serves as the passageway of the selection of content discussed in the media. It is assumed that individuals focus mostly about the product of media gatekeeping (McCombs and Shaw 2011). Since the media ultimately decides what events to broadcast through the media gates on the determination of what is considered newsworthiness, editors serve as a sort of gatekeepers itself. News comes from various sources, it is up to the editors to decide which story should appear and what should not, hence the term gatekeepers. Gatekeepers ensure that the right material is disseminated to the mass because some issues are considered important to the media but not the masses (McCombs and Shaw 2011). Priming is when the media gives the utmost importance to a certain event that it gives the audience the impression that the particular news is 
the most significant one. The chosen news report is carried over as the heading or the cover of the story regularly. Terms such as headlines, special news features, discussions, expert opinions are used mostly. The media primes the news by repeating the news and giving it more importance like for example, Coronavirus. Framing is a process of selective control, which has two meanings (McCombs and Shaw 2011). One is the way in which news content is typically shaped and contextualized within the same frame of reference. Two is how the audience adopts the frames of reference and to see the world in a similar way. This is how individuals attach importance to a piece of news and perceive its context within which an issue is viewed. Take for example, the coronavirus pandemic, the news reports were framed in such a way that they show countries in a positive light and others in a negative light. So, depending on which media individuals have access to, their perception will differ.

Some factors affecting agenda setting theory include: gatekeepers such as editors and managers and other external influences; non-media sources like government officials and influential personnel (McCombs and Shaw 2011). Some criticisms of agenda setting theory include: media users are not ideal and individuals may not pay attention to details; the effect is weakened for individuals who have made up their minds; the media cannot create problems, they can only alter the level of awareness, priorities, importance, etc (McCombs and Shaw 2011).

There is no clear cut or simple concept of media. Media is constantly evolving to the point that there are new technologies developing every single day. By developing new technology, it raises many questions on whether certain forms of communication are considered concepts of mass media. The first types of mass media were the types of drama in different cultures. The first book known is the "Diamond Sutra," which was printed in China in 868 A.D (Khan 2010). Although books were printed earlier than this, a form of movable clay type was 
invented in 1041 in China. Unfortunately, due to the high cost of the paper the earliest form of printed mass media was in European popular prints from around 1400. Johannes Gutenberg printed the first book using the first movable printing press in 1453 Khan 2010). His invention changed how one received printed materials. Books were too expensive around this time to be considered a form of mass media. However, newspapers developed around 1612 with the first example being in English in 1620, but it took until the nineteenth century to reach the mass audience. During the twentieth century, mass media was driven by technology and the mass duplication of media material.

Newspaper publications consist of news, information, and advertising, which is usually printed on low-cost paper called newsprint. The first printed newspaper was published in 1605 , and it has survived despite the many forms of media and technology platforms such as radio and television (Khan 2010). However, developments on the Internet pose challenges for this business model of newspapers. The paid circulation and advertising revenue is decreasing in most countries, which makes up the majority of the newspapers income. As a result, the newspapers are transitioning from print to online sources.

Mass media can be used for different audiences such as advocacy for business and social concerns such as advertising, marketing, propaganda, public relations, and political communication; better education; recreation such as acting, music, and sports, video and computer games; journalism like news and blogging; and announcements for all audiences (Khan 2010). Some negative forms of mass media include the inability to portray implicit knowledge such as corporate propaganda; the manipulation of large groups like media outlets for the advantage of a particular group or party; and bias or political form supporting a particular side with an expected outcome or solution (Khan 2010). 


\section{HISTORY OF DOCUMENTED SEXUAL ASSAULT}

Accounts of sexual assault cases have dated back to when history was first recorded. Tracing back to ancient Greece, to the Bible, to the letters of early explorers. Wars have been linked to sexual assaults, dating back to World War II where mass rape was committed by Soviet soldiers to sexual violence during the genocide in Rwanda in 1995. Some sexual assault cases that have influenced history include the rise of Alexander the Great. (History 2018). Another time where sexual abuse was highlighted was when the Roman historian, Livy, traces Rome's origins back to the mid-eighth century B.C. when the warrior tribe was faced with a shortage of women (History 2018). Just like what was observed with the Roman tribe, Celtic tribes and the Roman Empire were at a constant battle since the invasion of the Island of Britain in 45 A.D. and include violent atrocities against women (History 2018).

Several years later when Christopher Columbus conducted his voyage to the Caribbean in the 1490s, he not only discovered the new lands, one of his men also documented his own rape and torture of an indigenous woman. (History 2018). This inglorious history continues-- many enslaved women of color were assaulted by slave owners in the colonies and the United States before the end of the Civil War (History 2018). Surviving stories of these assaults were documented by escaped or freed slaves in such novels, Cradle of America: A History of Virginia and Incidents in the Life of a Slave Girl(History 2018). Years later in 1903, the Russian Empire stormed the town of Kishinev and included the murder of forty-nine Jews and the rape of Jewish women. (History 2018). This event would lay the framework for the brutal horrors that the European Jews would face forty-years later during the Holocaust (History 2018). 
In more recent times in America, 1994, a twenty-four-year-old woman, Recy Taylor, was kidnapped and gang raped by six men while walking home from church in Abbeville, Alabama The rape of Taylor and the reaction was a representation of the Jim Crow south era. As a result, this incident helped jolt the civil-rights movement. When the details of the incident were reported in the black press, the NAACP (National Association for the Advancement of Colored People) sent Rosa Parks to Abbeville to investigate the case (History 2018). Parks established and formed the Committee for Equal Justice for Recy Taylor, the leaders went on to organize the Montgomery Bus Boycotts. In 2011, the Alabama State Legislatures officially apologized to Taylor for its lack of prosecution.

It seems as though these historical accounts of sexual abuse all have something in common: lack of legal implications and a desire for power. Throughout history it was about dominance and power; retrieving land and gaining power over others. The law seemed to favor the elite and disregard the others. The individuals who have committed these crimes do not see their fault or think they can get away with it, while the victims are disadvantaged and are unable to pursue any legal action without the proper authority and direction.

\section{MALE PERPETRATORS}

A New York Times analysis has found that since the publishing of the \#MeToo movement and the accusations of sexual abuse, at least two-hundred influential men have lost their jobs after public allegations of sexual abuse (Carlsen et al. 2018). At least nine-hundred and twenty individuals came forward to say that one of these men behaved inappropriately and nearly half of the men who have been replaced were replaced by women. Forty-three percent of their replacements were women. One-third of these women are in news media, one-quarter in 
government, and one-fifth in entertainment and the arts. However, appointing a woman does not guarantee change. Women have also harassed and hid the harassment. Some women face the glass cliff, which is when women are appointed to leadership roles during organizational crises when the chance of failure is high. Women leaders tend to hire and promote women and pay them more equally with the goal of making companies more profitable. Women bring their life experiences and perspectives to decision making responsibilities and that can help in business because women make the majority of purchasing decisions. In government, women have been proven to be more collaborative and bipartisan and promote more policies supporting women, children, and social welfare. Listed above are some men who were replaced. Of the men who lost their jobs, fifty-one of those jobs have been replaced by at least one woman in an interim or permanent position (Carlsen et al. 2018). The dates for each entry were from 2017-2018 from when news broke of accusations, or when a firing, resignation, or other consequence was announced. Some men, however, have not been replaced. Most lost their jobs or standing and have no clear successors, or their replacements have yet to be named or are unknown.

In \#MeToo Brought Down 201 Powerful Men. Nearly Half of Their Replacements Are Women (Carlsen et al. 2018), lists the men and women accused of sexual abuse. Aaron Persky was removed from his Superior Court seat in California when voters recalled a sentence of a white Stanford swimmer to six months in jail for committing three sexual assault felonies on an unconscious woman. California made many legal changes in response to this case. Larry Nassar, a doctor for the Olympic gymnasts, was convicted of sexually assaulting his women patients under the disguise that it was treatment and was later sentenced to more than a lifetime in prison. There have also been ongoing allegations against Catholic priests and bishops by victims who are now adults and are speaking of their childhood abuse, which occurred before the \#MeToo 
movement. William D. Strampel, former Dean of Michigan State University Osteopathic Medical School, resigned from faculty after being arrested on charges of sexual harassment of students. He denied the accusations. For years, Strampel supervised Dr. Lawrence G. Nassar, a Gymnastics team doctor who pleaded guilty in November to molesting girls. Recent documentaries released on Netflix such as "Athlete A," and "Jeffrey Epstein: Filthy Rich," showcase the abuse young girls experienced under the care of high profile, well-known individuals. Both documentaries explain the survivors' stories of abuse when they were children, unaware at the time that it was wrong or had a feeling it was wrong but were too scared to speak up until they became women. Hundreds of women broadcasted their allegations against Larry Nassar and Jeffrey Epstein with the hope that they would stop this abuse with other children in the future. The documentaries exemplified that these men took advantage of vulnerable young girls under the disguise that they were trying to help them whether as a form of treatment in Larry Nassar's case or helping young girls develop their careers by sending them to other countries, giving them money, and enrolling them in prestigious schools like Jeffrey Epstein did. Because both of these men were well-known, these women were scared to speak out against them when they were younger in fear there would be retaliation or that they would be ostracized and humiliated. Many girls and women are unable to speak to this day due to NDA's (nondisclosure acts), which prohibit individuals from speaking out on behalf of an industry/company or individual otherwise legal actions will be taken against those who go against the agreement. For those individuals who did report the abuse right away they were told by those in power of the company or other officials that it would be taken care of to then not hear back about an initial investigation or to brush the abuse under the rug in fear of bad publicity. After waiting for an investigation to occur and even a follow up, some of the survivors decided to speak out against 
the abuse and those who tried to cover it up by going to news outlets or talking to the lead attorneys and lawyers involved with the case.

In recent years, it seems as though the Harvey Weinstein and Bill Cosby case have illuminated the \#MeToo movement, among other celebrities as well. However, both Weinstein and Cosby were high-profile celebrities. Cosby was an actor and comedian while Weinstein was a former film producer. During an extensive trial in New York, Weinstein was sentenced to twenty-three years for rape and sexual assault. He was considered one of Hollywood's most powerful figures; known by many people. Bill Cosby's first trial in 2017 ended on a mistral but was later found guilty of three counts of aggravated indecent assault during his retrial in 2018 . Cosby was sentenced to three to ten years. These elite celebrities took advantage of women serving underneath them. These survivors/victims repressed their abuse for many years and decided to come forth publicly in hopes that other women would do the same. Not only did the abusers illuminate the \#MeToo movement, but the survivors/victims who came forth publicly knowing that they would face a harsh audience also ignite the movement and sparked a revolution for change, empowerment, and justice for all women.

Sean Hutchinson, Olympic swimming coach, was banned from the U.S. Olympic activities after an investigation found that he engaged in sexual contact with a minor. Ariana Kukors Smith said he had sexually abused her when she was a teenager. However, he denied any abuse and said they had a consensual relationship starting when she was of legal age. Roger Ailes tied women's work prospect to sex many times, "If you want to play with the big boys, you have to lay with the big boys," he told a woman seeking a contract with the Republican National Committee in 1989 (Carlsen et al. 2018). "No girls get a job here unless they're cooperative," he is reported to have said this to a nineteen-year-old girl in the 1960s after he grabbed her and 
forcibly kissed her (Carlsen et al. 2018). Fifty years later, television host, Gretchen Carlson says Ailes demoted and fired her for refusing to have sex with him. Fox later settled Carlson's harassment case for twenty million dollars.

Dan Schoen, Minnesota state senator, resigned after allegations of sexual harassment from multiple women surfaced. He denied some of the allegations while claiming that others were taken out of context. He was replaced permanently by Karla Bigham. Tony Mendoza, California state senator, resigned after accusations that he made unwelcome advances toward several women. He denied the accusations and a State Senate investigation found that he "more likely than not" made unwanted advances. He was replaced by Vanessa Delgado as interim. Wes Goodman, an Ohio state representative, resigned after acknowledging he engaged in inappropriate behavior inside his office. Further accusations then emerged that he had engaged in this behavior for years of unwanted sexual advances towards younger men when he worked in Washington and had once groped a college student. He was replaced by an interim Riordan McClain. Blake Farenthold, a U.S. representative for Texas, dropped his re-election bid and later resigned amid harassment accusations and a report that he used taxpayer money to settle a sexual harassment claim brought by a former employee. He apologized for unprofessional conduct in the workplace and was replaced by interim Michael Cloud.

Roy Price resigned from his job as head of Amazon Studios after Isa Hackett, an Amazon producer, publicly accused him of repeatedly propositioning her in a cab on the way to a work party and loudly whispering obscene comments during public gatherings (Williams and Lebsock 2019). Albert Cheng was replaced as an interim and Jennifer Salke later replaced Price’s position. The head of news of NPR and former New York Times editor, Michael Oreskes was accused of sticking his tongue down the throat of someone during a discussion of job prospects. 
Oreskes resigned and apologized for his behavior. He has since been replaced by Christopher Turpin for interim and permanently replaced by Nancy Barnes. Chris Savino, creator of Nickelodeon's “The Loud House," was fired after allegations spread of sexual harassment from multiple women. He later apologized and Michael Rubiner replaced Savino as co-executive producer for the show. Mark Halperin, a political journalist for NBC News, Penguin Press, HBO and Showtime cut ties with Halperin after allegations surfaced of sexual harassment by former co-workers. He apologized and admitted to his behavior and was permanently replaced by Alex Wagner as co-host of Showtime's, “The Circus.” Rick Najera, director of CBS's Diversity Showcase, resigned after an investigation into accusations of his inappropriate behavior and comments to performers. He said he was confounded by deliberate and cruel defamations and Stephen Guarino and Grace Parra replaced him permanently. Kevin Spacey, an actor, was cut from his Netflix show, "House of Cards," and was replaced in the film, "All the Money in the World," after he was accused of forcing himself on a minor. Men have also come forward accusing him of inappropriate behavior. He later apologized and was replaced in roles by Robin Wright in the Netflix show, "House of Cards," and Christopher Plummer replaced him in J. Paul Getting in "All the Money in the World." Andy Dick, an actor, was fired from two films after accusations of sexual harassment. Dick was accused of kissing one of his colleagues and licking her. He pleaded not guilty to the sexual battery charge in July and denied claims of groping. Jonathan Pessin replaced him as Oliver in "Vampire Dad."

Charlie Rose, a television host, was fired by CBS and PBS after accusations of unwelcome sexual advances made by several women were reported. He said that he acted insensitively but that many allegations were inaccurate. Christiane Amanpour replaced Rose permanently as a host on "Amanpour \& Company." Glenn Thursh, a White House reporter at 
The New York Times, was suspended and then reassigned after sexual harassment accusations made by four female journalists surfaced. Katie Rogers permanently replaced him. John Lasseter, chief executive officer of Pixar and Walt Disney Animation, stepped down after accusations of unwanted hugging and other inappropriate behavior such as touching occurred in the workplace. He has apologized and is in a consulting position until the end of the year. He was permanently replaced by Jennifer Lee as chief executive officer for Walt Disney Animation Studios and Pete Docter as chief creative officer for Pixar Animation Studios. Matt Lauer, television news anchor, was fired from NBC after being accused of inappropriate sexual behavior toward a staff member and others said they were subjected to unwanted sexual advances. He apologized but said some of the accusations were untrue. He was replaced permanently in the role by Katie Couric for the co-host of the Winter Olympics and Hoda Kotb as co-anchor for NBC's “Today” show.

Johnny Iuzzini, chef and judge on ABC's “The Great American Baking Show,” was fired after accusations of sexual harassment, including unwanted touching of at least six former female employees. He denied some of the allegations and said none of his behavior was meant to hurt people. He was permanently replaced by Sherry Yard as a judge on the show. Leonard Lopate, a host on New York Public Radio, was fired after complaints surfaced of sexual harassment after violating standards for providing an inclusive, appropriate, and respectful work environment. Lopate said he had never done anything inappropriate on any level. He now hosts a show on the New York FM station WBAI, which is used as a podcast by the NPR affiliate Robin Hood Radio. He was permanently replaced by Alison Stewart as a host on "All of It." Bryan Singer, director and producer, lost his executive producer credit for the television series "Legion," after a lawsuit alleged that he sexually assaulted a seventeen-year-old boy in 2003 . He denied the 
accusations and days before the lawsuit was filed, he was fired as director of the movie, "Bohemian Rhapsody." He still retained a director's credit for the movie. He was permanently replaced by Dexter Fletcher as director in the movie.

T.J. Miller, an actor, had a show on "Comedy Central" which was canceled and dropped as the spokesman for Mucinex after a woman accused him of hitting and sexually assaulting her while in college. Miller denied the allegations and was replaced in the role by Jason Mantzoukas as the spokesman for Mucinex. Charlie Hallowell, chef and owner of three Oakland, California restaurants, sold two restaurants after seventeen former employees accused him of sexual harassment, including unwanted advances and sexual comments. He apologized and was permanently replaced by Jen Cramer and Richard Clark as co-owner of a restaurant Boot and Shoe Service, and Rico Rivera owner of a restaurant Penrose. Paul Haggis, screenwriter and director and founder of the charity Artists for Peace and Justice, resigned from his charity after accusations of rape and sexual assault. He denied the accusations and was permanently replaced by Ben Stiller as co-chairman of the board of Artists for Peace and Justice and Susan Sarandon as co-chairwoman of the board of Artists for Peace and Justice. Rob Moore, a managing editor for The New York Daily News, was fired after accusations of sexual harassment and sexual comments were reported. He was permanently replaced by Kristen Lee, but she left in August. Steve Wynn, chief executive of Wynn Resorts, resigned after accusations that he harassed female employees for decades and coerced them into having sex surfaced. He denied the allegations and was permanently replaced by Matt Maddox.

Wayne Pacelle, chief executive of the Humane Society, resigned after three women accused him of sexual harassment including forcible kissing and unwanted advances. He denied the accusations and was replaced by Kitty Block as an interim as acting president and chief 
executive. Paul Shapiro, vice president at the Humane Society, resigned in 2016 after six women complained that he sexually harassed them including making inappropriate jokes and asking for sex. He resigned in 2018 shortly before Politico made the allegations public. He denied the accusations and said his resignation was unrelated to these incidents. He was permanently replaced by Josh Balk. Paul Marciano, executive chairman of Guess, Inc, resigned after several women accused him of sexual harassment and assault. After a company investigation, they found that he exercised poor judgement. He denied the allegations and was replaced by his brother, Maurice Marciano. Jorge I. Dominguez, professor at Harvard University and chair of the Harvard Academy, resigned after eighteen women accused him of sexual harassment and assault including unwanted touching that had been going on for decades. He denied the allegations and was replaced by interim Timothy J. Cotton and then permanently replaced by Melani Cammett as chair of the Harvard Academy. Jeff Franklin, showrunner for "Fuller House," was removed after accusations that he was verbally abusive and made sexually charged comments in the writer's room and on set. He was permanently replaced by Byran Behar and Steve Baldikoski. Bill Hybels, lead pastor of Willow Creek Church, retired after a group of former pastors and staff members accused him of sexual misconduct in which he called them lies. He later apologized for making people feel uncomfortable and has since been permanently replaced by Heather Larson and Steve Carter, who left in August and Steve Gillen who started in August as interim lead pastor.

Demos Parneros, chief executive of Barnes and Noble, was fired without public explanation, but was later revealed that the termination was because of accusations surfacing of sexual harassment by an executive assistant. He said the interactions were not harmful or offensive and was replaced by interim Leonard Riggio as executive chairman overseeing a team 
that shares the duties of the office of the chief executive. Leslie Moonves, president, chairman and chief executive of CBS Corporation, left CBS after a dozen women accused him of sexual misconduct and retaliated against those who rejected his advances. Moonves said he may have made some women uncomfortable but never misused his position. He was replaced by an interim Joseph Ianniello as president and acting chief executive officer. Ken Baker, a journalist for the E! Network, left after two women accused him of sexual harassment. Brett Ratner, a producer and director, lost a production and financing deal with Warner Bros after he was accused of sexual assault or harassment by six women. A lawyer on behalf of Ratner said that he denied all allegations. Danny Masterson, an actor, was fired and cut from a Netflix show, "The Ranch,” after accusations surfaced that he raped four women in the early 2000s. Mark Schwahn, showrunner of "One Tree Hill," and "The Royals," was fired from "The Royals," after multiple women accused him of sexual harassment. He did not publicly respond to the accusations. Tom Sizemore, an actor, dropped as male lead from a horror film, "The Door," after a report surfaced that he groped an eleven-year-old actress on a movie set in 2003. He denied the accusation and was sued by the actress. Andy Henry, a casting director for Nancy Nayor Casting, was fired after it was revealed that he had been dismissed from his role as a casting employee on "C.S.I," in 2008 after several women said that he urged them to disrobe during auditions. He apologized, left Nancy Nayor Casting, and a new team was assembled.

Jerry Richardson, owner of the Carolina Panthers NFL team, was fined $\$ 2.75$ million by the NFL after an investigation into sexual harassment of female employees. Richardson later sold the team for $\$ 2.2$ billion. He did not comment on the allegations. He was replaced by Tina Becker as an interim chief operating officer and permanently replaced by David A. Tepper as the owner. Donovan McNabb, radio host on ESPN and former N.F.L. The player was fired by ESPN 
after a former NFL Network wardrobe stylist said in a lawsuit that he sent her explicit messages. The lawsuit was settled in September. Eric Davis, radio host on ESPN and former N.F.L. player, was fired after a former NFL Network wardrobe stylist said in a lawsuit that he groped her and made inappropriate comments. The lawsuit was settled in September. Marhsall Faulk, an analyst for NFL Network, was suspended and will not be returning after a former NFL Network wardrobe stylist said in a lawsuit that he fondled her and pulled out his genitals while demanding oral sex. The lawsuit was settled in September. Ryan Lizza, writer for The New Yorker and political analyst for $C N N$, was fired by The New Yorker and suspended by $C N N$ over an accusation of “improper sexual conduct," which Lizza denied. He has since returned as a CNN analyst after a CNN investigation "found no reason to continue to keep Lizza off the air." He was hired in June by Esquire as its chief political correspondent. Heath Evans, analyst for NFL Network and former NFL player, was suspended and then terminated by the network after accusations of sending a co-worker explicit photos surfaced. He said the accusations were false. Ike Taylor, an analyst for NFL Network and former NFL player, was suspended after accusations of sending a co-worker sexually inappropriate photos and videos were reported. He eventually lost employment from the network.

Tavis Smiley, a host of $P B S$ talk show, "Tavis Smiley," $P B S$ stopped distributing his show after an investigation found "credible allegations" that he had sexual relationships with employees. Some witnesses stressed concern that their jobs were tied to the continuing relationships, which Smiley said were consensual. He later filed a lawsuit against $P B S$ and it filed a countersuit, detailing more alleged sexual misconduct. He now hosts a show on The Word Network. Brad Kern, producer of "NCIS: New Orleans," was fired after an investigation was reported of sexual misconduct including sexual harassment, discrimination, and making racially 
insensitive comments. Patrick Witty, deputy director of photography at National Geographic, left in December when multiple women accused him of sexual harassment including unwanted touching and kissing in January. He denied the accusations but apologized for some behavior. James Dashner, author of "The Maze Runner" series, was dropped from Random House and his literary agent after accusations surfaced of sexual misconduct. He said, "I am taking any and all criticisms and accusations very seriously, and I will seek counseling and guidance to address them." Greg Kadel, a fashion photographer, was suspended by Victoria's Secret and Conde Nast cut ties with him after sexual misconduct accusations from models who said he harassed and assaulted them when they were teenagers were reported. A spokeswoman for Kadel said he never sexually coerced or assaulted anyone. Morgan Freeman, an actor and producer, Visa suspended a marketing campaign featuring Freeman after eight individuals accused him of sexual harassment or inappropriate behavior. Freeman apologized saying that he would not "intentionally offend or knowingly make anyone feel uneasy."

Roman Polanski, a director, was expelled from the Academy of Motion Picture Arts and Sciences after a woman came forward and said she was sexually assaulted when she was tenyears-old and started a petition to remove him. The Los Angeles Police conducted an investigation into the accusation, which Polanski denied. Previously, however, Polanski pleaded guilty to having sex with a minor in 1977 and fled the country before sentencing. Over the years, he was accused by six women of sexual abuse, most happened when they were minors. He has continued to make films in Europe.

As you can see, these male perpetrators took advantage of their high-profile positions to prey on those who served underneath them and those who seemed vulnerable. These male perpetrators did not only abuse women and underage girls but men and underage boys as well. It 
is also noticeable that even though some of these male perpetrators are accused and have either been fired or resigned from their positions, some face no legal consequences. Some male perpetrators have settled lawsuits with the survivors/victims to keep the news from reaching the mass public, some male perpetrators were under investigation with no follow-up or if there was any follow-ups nothing more was acted upon. Others were sentenced and convicted, but for the majority it appears as though most are accused with no legal repercussions in place.

\section{FEMALE PERPETRATORS}

Overall, fewer women have faced accusations of misconduct in the \#MeToo movement era, but several who did also faced employment consequences. Cristine Garcia, California state assembly woman, was removed from committee posts after sexual harassment accusations surfaced from a former legislative employee. An investigation was conducted and found no wrongdoing, but it was reopened after an appeal. She has denied the accusations and is running for a fourth term. The interims who replaced her, Al Muratsuchi as acting chairman of the Assembly Natural Resources Committee and Susan Talamantes Eggman as acting chairwoman of the California Legislative Women's Caucus. Andrea Ramsey, a candidate for U.S. House seat in Kansas, ended the campaign after accusations that she had sexually harassed and then fired a former employee. She denied the accusations. Asia Argento, an actress and director, was removed as a judge on "X Factor Italy," after reports surfaced that she had sexually assaulted and then paid off a seventeen-year-old former co-star in California. She denied the accusations. CNN also removed episodes of “Anthony Bourdain: Parts Unknown,” featuring Argento from the streaming service. 


\section{SURVIVORS}

Some cases involving sexual abuse that were reported to The New York Times (Ryzik et al. 2018) in 2017 include: Wendy Walsh, spoke publicly about her sexual harassment allegations against Bill O'Reilly in April 2017 investigation in The Times, which exposed millions of dollar settlements involving the Fox News host and led to his excommunication from the network. Six other women were locked into confidentiality agreements totaling forty-five million dollars. Walsh was a guest on “The O'Reilly Factor," and accused O'Reilly of breaking his promise to her making her a contributor after she declined an invitation to his hotel room in 2013. O'Reilly has denied all allegations against him. Walsh now works as an adjunct professor of psychology at California State University and Channel Islands as a radio host for KFI AM 640 with iHeartMedia.

Individuals experience sexual assault and harassment in the workplace environment from their bosses, co-workers, etc. Trish Nelson, reported being harassed by Mario Batali and Ken Friedman at the Spotted Pig in Manhattan's West Village. Batali was a regular and an investor at the restaurant as well as chief and restaurant owner and co-host of the ABC show, "The Chew," which was co-owned by Friedman and the chef April Bloomfield (Ryzik et al. 2018). Nelson was a long time employee who resigned in 2012 after Friedman tried to kiss her and touch her breasts in his car, pinning her against the passenger side door. ABC fired Batali and had to divest from his restaurants. Batali later said he did not remember the specific incident, but apologized and admitted that he had behaved terribly. Friedman acknowledged his behavior and claimed the incident was not as described.

Natalie Saibel was the first of a dozen women who went on the record with The Times in December of 2017 with complaints that they were harassed by Ken Friedman, an influential 
restaurateur in the country (Ryzik et al. 2018). A longtime server at the Spotted Pig, his popular West Village restaurant, Saibel made a formal complaint in 2015, when Friedman ran his hands over her buttocks and groin in front of customers. She was fired soon after, in which managers claimed her long-established schedule no longer conformed to the restaurant policy. Friedman took an indefinite leave of absence and dissolved his partnership with April Bloomfield and split up ownership of their restaurants. Friedman soon apologized for his behavior and took an immediate leave of absence from the restaurant group he ran with chef April Bloomfield. The partnership has since been eliminated.

Individuals who work in the music industry and help artists produce their music and find new talent to record also face sexual abuse. Drew Dixon, a one-time music executive at Def Jam and Arista Records, who worked with well-known celebrities such as Mary J. Blige, Lauryn Hill, Santana, and Aretha Franklin reported to The Times in 2017 that the music mogul Russell Simmons raped her at his downtown Manhattan apartment in 1995 after months of aggressive sexual harassment in and out of the Def Jam office (Ryzik et al. 2018). Simmons has been accused of rape by multiple women and has denied all allegations. She also was later sexually harassed repeatedly while working under another record label boss, L.A. Reid, subsequently driving her from the music industry. Reid later apologized if anything was misinterpreted.

Tina Baker, a singer who has performed with Madonna and Bruce Springsteen among other celebrities and released her own albums in the 1980s and 1990s, accused her manager, Russell Simmons of raping her in his Manhattan apartment. This experience led her to quit singing for decades and is now a tech industry lawyer leading a forty-five person firm in London. She was one of many women who accused Simmons of rape. Simmons denied all allegations. Toni Sallie, a music journalist and promoter was one of three women who said Russell Simmons 
raped her in his Manhattan apartment. Russell Simmons, co-founder of Def Jam Recordings and other businesses, stepped down from his companies after accusations surfaced of sexual assault and rape from multiple women. He denied the accusations.

Chris Brown (not the rapper and song-writer) played principal in the St. Paul Chamber Orchestra for more than three decades. In 2017 he reported to The Times that he was sexually abused at the age of seventeen by the Metropolitan Opera conductor James Levine, who served on the faculty of the residential summer program where Brown studied (Ryzik et al. 2018). He was one of several accusations that prompted the Metropolitan Opera, where Levine had served as music director for four decades, an open investigation was conducted into Levine's behavior. Levine was fired and denied all accusations and is suing the Met for breach of contract and defamation. He was replaced permanently by Yannick Nezet-Seguin.

Kenny Sale, a model reported in March that she was assaulted by the photographer, Mario Testino, in California in 2015 (Ryzik et al. 2018). The company severed ties with Testino after thirteen male models accused him of sexual advances including groping and masturbation. He denied any wrongdoing. Sale was one of many individuals who reported Testino's behavior. After a January report came out about Testino and another photographer, Bruce Weber, who used their positions as passageways of the fashion industry to harass models and assistants. Both Testino and Weber denied the allegations.

Business owners and entrepreneurs also face sexual abuse and violence when networking with other business entrepreneurs to grow their business and to acquire more revenue. Lindsay Meyer, an entrepreneur reported to The Times in 2017 how Justin Caldbeck, an investor, pledged to invest twenty-five thousands of his own money in her first start-up company, he sent her harassing messages, groped her and tried to coerce her into a sexual relationship (Ryzik et al. 
2018). She felt like she had to tolerate it because this is the cost of being a nonwhite female founder. Helen Donahue, a writer and social media director, reported to The Times in 2017 that a former Vice Media employee, said that the company executive had grabbed her breasts and buttocks at a Vice holiday party (Ryzik et al. 2018). She said that when she reported the incident to the head of human resources, she was told that it was not sexual harassment but rather someone making a move on her. She left Vice in 2016.

Abby Schachner, a writer, illustrator and performer reported in November 2017 how the comedian Louis C.K. masturbated during a business phone call with her, one of five women who came forward with stories of inappropriate behavior involving masturbation, all of which Louis C.K. admitted to (Ryzik et al. 2018). Louis C.K. lost his production deal with $F X$ and the distribution for a film he wrote and starred in was canceled and he lost his voice role in "The Secret Life of Pets" franchise. He recently began performing again unannounced at comedy clubs in the New York area. He was replaced in the role by Patton Oswalt in the movie. In January, David Chappelle addressed the women, calling them weak and not cut out for the entertainment industry and singling out Schachner's experience. Schachner did not watch Chappelle's special but she removed herself from the comedy world.

Individuals who come forth about their abuse risk facing scrutiny from peers, coworkers and colleagues, family members, etc. Those who come forth about their abuse can be made to feel ashamed about speaking out and others might outcast the individual. Though not reported to The Times, in 1991, Anita Hill testified before the Senate Judiciary Committee that Clarence Thomas, who was a nominee to the Supreme Court, had sexually harassed her (MacKinnon 2019). The Senators subjected her to a humiliating interrogation, which was overlooked by an audience on national television. Another former employee had also come forth of Thomas' 
abuse, but she was never called to testify. Instead, Hill had to endure the inquisition of the allmale committee's bullying alone. After the hearings, Hill's position at the University of Oklahoma was so difficult due to this opposition that she had to leave, which proved to show a lesson to those who ever raised a charge against sexual abuse.

From the accounts listed above it seems like there are blurred lines when it comes to the understanding of what constitutes appropriate and inappropriate behavior. Though behaviors of what is right and wrong seem to be obvious on the surface, it may not be so easy to understand and to communicate to some individuals. Behavior like this might be asserted due to dominance of power, those serving in top positions within a company might use their power to take advantage of those serving underneath their title. The survivors of these encounters are sometimes offered a better salary or position if they abide by the behaviors being asked of them. As a result, if the survivors speak out against wrongful behavior they risk being fired or outcast by individuals. Some individuals are even coerced into signing non-disclosure agreements to silence them from speaking out against their abuser. If one breaks a non-disclosure agreement they run the risk of facing severe legal repercussions and fines.

\section{\#METOO IN ITS CURRENT CONTEXT}

Though the Me Too or \#MeToo movement has been around since 2006 and reintroduced in 2017, the movement made a comeback when multiple women decided to come forth about their prolonged abuse they endured under the guise that Harvey Weinstein was a profound American film producer who could help individuals advance their careers. These individuals who came forth about Weinstein faced years of abuse and torture under his power and some remained under the abuse in fear he would retaliate and fire them. The Weinstein case and many 
other cases only lit a spark under the movement, but the survivors/victims who came forth against their abuser ignited the movement as a whole. The movement not only aims to target specific individuals who are the abusers, but the movement's goal is to broadcast appropriate behaviors in the workplace and daily life and challenge the judicial system to strategically analyze cases involving sexual abuse and violence and provide the proper justice. The movement also seeks equality and for women's voice to be heard and their rights to be recognized. Harvey Weinstein, an American film producer, ignited the \#MeToo movement when sexual assault allegations spread in October of 2017 (Weinstein Timeline 2020). Among the accusations he was also alleged to have forced women to massage him naked and promised to advance their careers in return for sexual favors. Weinstein denied the allegations and decided to take a leave of absence from the Weinstein Company. He was later kicked out by the board of his own company. After multiple women came forth about Weinstein's sexual advances, he later resigned from his company and was stripped of many awards and medals he won throughout his tenure in the Hollywood business. Weinstein bribed his victims with money in order to silence them, but many of the victims refused and came forth anyway. He used non-disclosure agreements (NDAs) to silence these victims and let his acts go unnoticed to the public eye. Weinstein ended up turning himself in in May of 2018 for sexual misconduct charges. He was then charged with rape and several other sexual abuse allegations. He was later released on a one-million dollar bail and forced to wear a GPS tracking device. In May of 2018 New York indicted Weinstein of rape and a sexual act on a woman in 2013 and another in 2004 and pleaded not guilty. He continued to face several trials of sexual abuse towards women and remained to plea his innocence against the allegations. In February of 2020, Weinstein was found guilty of criminal sexual acts in the firstdegree and third-degree rape. He was convicted of sexually assaulting a former production 
assistant Mimi Haleyi in 2006 and raping ex-actress Jessica Mann in 2013. Though he was still cleared of most of the charges against him, Weinstein still faces up to twenty-five years in prison. The judge ordered that he be held in custody until his sentence hearing in March of 2020. The Weinstein Company ended up going bankrupt and was bought and rebranded as Lantern Entertainment. Andy Mitchell and Milos Brajovic were appointed co-president of Lantern Entertainment. Weinstein's lawyers are looking to appeal his conviction.

\section{LEGAL IMPACTS}

This movements aim is to not only focus its attention on sexual harassment and violence in the scope of Hollywood, but in the broader workplace context. Today, there are more highprofile female performers than ever before, bringing new perspective to mainstream audiences and a heightened interest in exposing rape culture (Greene and Day 2020). States are making improvements by extending the timeframe of when victims can file a lawsuit against the perpetrators. The increased public attention has inspired changes in federal guidelines, state laws, and campus policies on sexual violence as well as social movement activity by survivor-activists and emerging counter-movements (Gronert 2019). Non-disclosure agreements, which are contracts aimed to keep the victims quiet about the abuse by compensating the victims financially have been tweaked to limit how they will be used in harassment claims. The \#MeToo movement has forced corporations and the entertainment industry, as well as state and federal executive and legislative branch officials, to take a hard look at gender inequities and sexual harassment in the workplace (Gunderson 2019). The movement is also focusing on nondisclosure agreements which are used to silence victims. Since 2017, at least twelve states have passed laws restricting the use of these agreements (Kantor 2020). New Jersey has made the 
agreements unenforceable if victims break them. California also passed a new law to restrict confidentiality agreements once a lawsuit or formal complaint has been filed, but many settlements are signed earlier in the process. Google, Microsoft, Uber, and Conde Nast have also agreed to disregard the agreements (Kantor 2020). Women have even gone against the nondisclosure agreements to come forth about their abuse and pave the way for change. Some examples include, McKayla Maroney sued U.S.A. Gymnastics to be released from an NDA she had signed involving Larry Nassar, USA gymnastics doctor. She was not penalized for breaking the agreement. Several other women who accused R. Kelly, an American singer and songwriter, of sexual abuse have spoken out against him despite the agreements made and four accusers in the Harvey Weinstein case have done the same. However, many victims are still bound to this agreement and cannot go against them due to the extraordinary risk such as financial penalties.

Other legal impacts have occurred due to the mass amounts of allegations that have become publicized. The internet now enables victims to go public with accusations bypassing the gatekeepers who have the ability to bury or hide stories from the public eye. A centuries old stereotype of calling women a "Vengeful Lying Slut," due to coming forth about their abuse has now been drained of its power by feminist activists who refer to this as "slut shaming," and reversed-shamed those who caused and encourage this stereotype. Women have also succeeded into positions of power such as the press, corporations, Congress, and Hollywood that they no longer have to play along with boy's club, they can lead the change. Many states define sexual assault and related offenses differently. For example, New York law prohibits "forcibly touching the sexual or other intimate parts of another person for the purpose of degrading or abusing such person or for the purpose of gratifying the actor's sexual desire." The statute added that this “include squeezing, grabbing or pinching." Quid pro quo harassment, which is defined as making 
sexual favors in a workplace environment in order for advanced job opportunities such as a promotion, raise, or other benefit is considered illegal. To win a lawsuit alleging this behavior, an individual has to prove that someone with authority made threats to take negative employment action unless the individual engaged in sexual behavior.

\section{BACKLASH}

Even though the \#MeToo movement has become a media sensation, it differs from what the actual true purpose of the movement is supposed to be, which is to help the survivors seek help, not call out the perpetrators; it threatens sexual freedom. Some men are being accused and forced to confess to these sexual abuse allegations they have not committed due to the constant pressure put on them. There is an argument that this movement or project both instantiates and critiques, an appeal to the "good man" (Crawley and Simic 2019). Sexual assault and harassment have been broadcasted on many platforms and the survivors/victims are mostly women.

Accusing an individual of sexual assault and harassment can be detrimental to an individual's reputation among society regardless of whether the accusation is proven true or false. Once it is broadcasted to the public, the accusation has to be true right? No necessarily. It can be tricky and difficult to determine whether these accusations are true or false. The last few years there have been an increasing discussion of sexual violence in the mainstream media and public debate in North America and elsewhere, especially with the most recent wave of sexual assault and harassment allegations in entertainment, media and public institutions (Crawley and Simic 2019). Women are coming forth about their experiences and those women who do not come forward are sometimes considered traitors or cowards. Within employment, women will be considered liabilities and could be limited with how they move up in the field. Another argument 
is stated that the \#MeToo movement is a vigilance movement designed to keep the distance away from the other gender. Men have expressed the desire and concern to keep away from women due to the fact they do not understand what actions would constitute inappropriate or wrong behavior to exhibit without getting into trouble of any kind.

A new study which will be published in the journal, Organizational Dynamics, states that men are more hesitant to interact with female colleagues (Mahdawi 2019). This study was conducted in early 2019 across a range of work industries. The study reflects that twenty-seven percent of men avoid one-on-one meetings with female colleagues, which is almost a third of men. Twenty-one percent of men said they would be reluctant to hire women for a job that requires close interaction such as business travel compared to fifteen percent of men in 2018 . Nineteen percent of men said they would be reluctant to hire an attractive woman. Women also are increasingly hesitant to hire other women. A 2018 survey found that more than ten-percent of men and women said they expected to be less willing than before to hire attractive women. Included in this study was the researchers examined nineteen behaviors such as emailing sexual jokes to a subordinate and seeing if the subjects classified this as harassment or not. Both genders agreed on what harassment entails. Leanne Atwater, a professor at the University of Houston and one of the study's authors said, “The idea that men don't know their behavior is bad and that women are making a mountain out of a molehill is largely untrue. If anything, women are more lenient in defining harassment."

Research from LeanIn.org and SurveyMonkey revealed that a whopping sixty-percent of male managers were uncomfortable joining in common job-related activities with women, such as mentoring, working alone together or socializing together (Elsesser 2019). The Pew Research Center found that fifty-one percent of employees reported feeling that the \#MeToo movement 
made interactions with the opposite sex at work more difficult. However, prior to the \#MeToo movement The New York Times indicated that twenty-two percent of men were reluctant to meet one-on-one with a woman. However, the latest research shows that male and female employees are more likely to speak out about harassing behavior as a result of the \#MeToo movement.

\section{QUANTITATIVE HYPOTHESES}

This research paper takes on a mixed methods approach, where both quantitative and qualitative techniques of content analyses will be applied to a sample of National and International newspaper articles. The section below discusses quantitative hypothesis pertaining to research examined throughout the sample set of newspaper articles. Throughout this research section, the following question will be asked:

Research Question Quantitative: What determines the portrayal of the \#MeToo movement in the media in newspaper articles?

Newspaper and broadcast journalism occupies a central place in the modern mass media and although there has been a dramatic increase in the number of women working in journalism, the glass ceiling still keeps most women out of senior management positions. It is stated that news is not simply mostly about and by men, it is overwhelmingly seen through men. In The Role of Gender in Scholarly Authorship, it appears that gender disparities are decreasing in academia in many aspects such as grant funding, hiring, acceptance at scholarly journals, and productivity (West et al. 2013). A study was conducted that analyzed a large-scale of over eight million papers across natural science, social science, and humanities that revealed a number of understated gender inequities. It was discovered that raw publication counts seem to be equal between the genders, however with close inspection it shows that men predominate in the 
prestigious first and last author positions (West et al. 2013). Women are significantly underrepresented as authors of single-authored papers. It states that gender inequities and gender biases persist in higher education. Women are not evenly represented across author positions. It is stated that academic publishing is very important to being hired as a faculty member and being promoted, the under-representation of women as authors in academic publications and in more prestigious authorship positions potentially affects the representation of women faculty in academia.

The \#MeToo movement has breathed a new life into the women's movement and especially into understanding and rectifying sexual harassment, abuse and assault (Clair et al. 2019). It has galvanized activists around the globe. And it has placed thousands of stories of the harassed in full view of the public. Sexual harassment, abuse, and assault may occur within the organizational context or beyond; but sexual harassment, in particular has been legally labeled an organization phenomenon. The \#The MeToo movement continues to unravel. Reports of sexual harassment and assault continue into the academic field, emerging across disciplines, regions, and statuses. It is important to not only address harassment in the workplace, but also in the academic sphere as well; to consider the intersections of academic power and systems of oppression and advantage (Flores 2020).

When it comes to recent shocking and unsurprising sexual harassment revelations in the media, in politics and in business it's easier to wonder if this is ultimately just another case of: the more things change, the more they stay the same (Keyton et al., 2018). Sexual harassment remains a persistent workplace problem. The 2017 \#MeToo movement and what-have-come-tobe news stories about sexual hostility, sexual assault, and sexual harassment in American organizations have opened wounds and reinvigorated public commentary. Although the Equal 
Employment Opportunity Commission sets forth guidelines for organizations to follow, questions remain about what counts as sexual harassment, and what is an organization's responsibility in maintaining a harassment-free workplace for its employees (Keyton et al., 2018). At the invitation of the editor, seven organizational communication scholars responded to a series of questions addressing seven issues related to sexual harassment. These are: sexual harassment policy and training; the responsibilities of bystanders of sexual harassment; organizational culture that provides more support to the harasser than the harassed; the intersection of race with sexual harassment; same-sex harassment and female-to-male harassment; and what can be learned from public movements. Due to the \#MeToo movement it has forced corporations, entertainment industries, and state and federal executive and legislative branch officials to take into account gender inequities and sexual harassment throughout the workplace (Gunderson, 2019).

When women are included as news sources, as several feminist researchers have argued, they tend to be defined in terms of their status vis-a-vis the principal (typically male) news actor in a particular story (Carter et al. 2002). Women are routinely presented either as an anonymous example of uninformed public opinion, as housewife, consumer, neighbor, or as mother, sister, wife of the man in the news, or as victim - of crime, disaster, political policy. Thus not only do they speak less frequently, but they tend to speak as passive reactors and witnesses to public events rather than as participants in those events (Carter et al. 2002). This gendered division is linked, in turn, to an alignment of 'serious' news values with public-sphere events deemed to be of interest to men, whilst so-called 'women's issues' are more likely to be framed in relation to the 'private' or domestic sphere. 


\section{H1: Female authors are more likely to provide a critical tone for the \#MeToo} movement than male authors.

An investigative study was conducted to examine the volume of foreign news provided by public service and commercial television channels in countries with different media systems, and how this corresponds to the public's interest in and knowledge of foreign affairs (Aalberg et al. 2013). In an investigation, researchers used content analyses of television newscasts and public opinion surveys in eleven countries across five continents to provide new insight into the supply and demand for international television news. It was found that more market-oriented media systems and broadcasters are less devoted to international news, and the international news offered by these commercial broadcasters more often focused on soft rather than hard news. Furthermore, the results suggest that the foreign news offered by the main television channels is quite limited in scope, and mainly driven by a combination of national interest and geographic proximity.

H2: The national media in the United States is going to provide a more critical analysis on the \#MeToo movement in America more than international media.

We can expect thus that new coverage on the \#MeToo movement will be more publicized in regions where sexual abuse has been reported more frequently versus regions that have not experienced sexual abuse or harassment. For example, New York and California will be popular news coverage regions because those areas have been under the limelight for the \#MeToo movement and celebrities/officials have been involved in sexual victimization cases.

H3: The critical tone of coverage of \#metoo movement in the media will vary by region of publication in the United States. 
Contemporary feminist scholars and activists often criticize the women's movement for focusing on a narrow agenda that does not represent the true needs of American women (Barakso and Schaffner, 2006). Yet a review of the agendas of women's movement organizations reveals a broad concern for many of the issues that they are criticized for ignoring. What explains the disconnect? The authors argue that the news media plays a crucial role in shaping the perceptions of social movements by choosing to cover some agendas and not others (Barakso and Schaffner, 2006). Analyzing coverage of women's movement organizations in television and print news media, the authors find that reporters have exercised a great deal of discretion over which women's movement issues they have chosen to report on during the past three decades. Given the momentum of the \#MeToo Movement in 2006-2017, it is unlikely that the movement received more attention than recent times where the COVID-19 pandemic and other social issues have taken priority in the media. While the movement is still mentioned, more issues have come into the spotlight and the media could have been more critical of the issue. Currently, the media may still report on the movement, but a critical tone might be diluted.

\section{H4: The coverage of the \#MeToo movement was more prominent in the years of origination (2006-2017) than recent times.}

The momentum of the \#MeToo movement has broadened the reach of the campaign that activist Tarana Burke started in 2006 to help women of color from under-priviliged communities who have experienced rape or sexual assault (Leung and Williams, 2019). The campaign received little mainstream media attention until eleven years later, when the phrase was used by prominent white women to share their stories of sexual assault through social media. While the movement has found success because of the added factor of race. Individuals have differing opinion of what ignited the \#MeToo movement, the focus on the Anita Hill and Clarence 
Thomas reports of October 1991 make it a starting point. The allegations women have brought forth have produced a grassroots movement against sexual harassment across all sectors such as high-profile celebrity cases that attracted the public's attention; the use of social media platforms; the \#MeToo movement that facilitated the survivors to speak publicly (Gibson et al., 2019).

Celebrities have long been involved in politics. Politicians have become celebrities (Barack Obama), and celebrities have become politicians (Ronald Regan). Celebrities stump for causes (Bono) and take on roles as international ambassadors (Angelina Jolie) (Larabee, 2018). However, there has never been a political movement spearheaded by celebrities as the \#MeToo movement against sexual abuse, which founded its energy in Hollywood. With the \#MeToo movement we can now see a new celebrity formation emerging in which the personal is both public and political. A study was conducted in which it was discovered that celebrity advocacy focuses on the ability of celebrities to help causes make news and capture the public's attention

(Thrall et al. 2008). However, after much consideration the article states that celebrities also have the ability in the political sphere as well and that celebrities play a role as part of an emerging strategy for political advocacy. It is difficult for most groups to make news but it can be made possible through the evolution of technology and the public sphere (Thrall et al. 2008). This new celebrity advocacy strategy represents a shift in American politics being accompanied by the digital age.

H5: Celebrity incidents of the \#MeToo movement will receive more media attention than non-celebrity incidents.

News coverage of celebrities were once confined to tabloid and specific magazines and special sections of newspapers (Dubied and Hanitzsch 2014). Now, celebrity news is 
everywhere. It has broadened to the entire media spectrum. Celebrity news provides the audience with scandalous drama and delves into their private lives and fuels celebrity worship. Celebrity news also plays in the political economy of the media. Celebrity news may distract the public from more pressing issues in public conversation. There is an argument among the journalism sphere that celebrity news can appear both revealing and worthwhile, however celebrity news tests the boundaries between fact and fiction and often appears as an advertising and public relations proposition. Celebrity news also tests the boundaries of media law and professional codes of conduct when revealing personal information. However, there is little scholarly research conducted about celebrity coverage.

\section{H6: News articles which discusses physical victimization are more likely to take a} critical tone in reporting then those that discuss non-physical victimization.

The United States started to confront rape and incest, wife-beating, stalking, workplace sexual harassment, and sex trafficking with multiple efforts in the late 1960s and 1970s (Ake 2017).These efforts were shaped by civil rights and second-wave feminist activism that recognized there were systematic injustices and became motivated to act. The most organized efforts to confront this violence have been the battered women's and anti-rape movements. This began as a series of responses to the needs of women who had been victims of male violence and to the larger systems that had long condoned and legitimized such behaviors.

A prior study examined women who had experienced childhood sexual abuse and the increased risk for sexual victimization and post-traumatic stress disorder (PTSD) entering into adulthood (Schaaf and McCanne 1998). In this study the researchers compared groups of participants who reported childhood sexual abuse only (SA), with childhood physical abuse only (PA), with combined childhood sexual and physical abuse (CA), and then no child abuse (NA). 
A sample of 475 female colleges students participated. The measures of sexual and physical abuse in childhood (before age 15) and adulthood (after age 15) were considered in this study. Of these participants, 27 were assigned to the SA group and 53 were assigned to the PA group, 31 were assigned to the CA group, and 211 were assigned to the NA group. The results indicated that the highest rate of adult sexual and/or physical victimization was reported by the CA group, followed by the PA group, with lower rates reported by the SA and NA groups.

\section{H7: Cases which are under investigation receive more critical attention than cases}

\section{that have reached a legal outcome.}

The news media can act as a powerful influence on the civil litigation system, in which the media influences decision making in particular cases and on the system as reports influence the decision making of various individuals participating in the system (Robbennolt and Studebaker 2003). A study was conducted which concluded that news reporting of civil litigation presents a distorted image of civil litigation and that reporting can influence individuals' perceptions and outcomes of civil litigation in many ways. 


\section{METHODS}

This research takes on a mixed methods approach, which means that the researcher will analyze both quantitative and qualitative data within the same study. This mixed methods approach will examine newspaper articles that will address the research questions. In the subsequent section the methods of data analysis will be discussed, along with the findings from qualitative and quantitative analyses. Finally, the findings will be examined from practical and theoretical perspectives. Throughout the research process, the following questions will be asked:

Research Question Quantitative: What determines the portrayal of the \#MeToo movement in the media in newspaper articles?

Research Question Qualitative: How is the \#MeToo movement portrayed in the media in newspaper articles?

\section{SAMPLE}

It was decided that vast array of newspaper articles that range from National to International that BBC, The New York Times and America's NewsBank would be used. These three newspaper publications are the three sample sets used throughout the research paper. When searching for relevant articles pertaining to the research, the hashtag \#MeToo movement would be used in the search bar of each sample set search browser. After the newspaper articles were collected from each sample set, they were copied and pasted onto a WORD document and then numbered one through one-hundred and fifty for each sample set.

A total of one-hundred and fifty articles each from BBC, New York Times, and America's NewsBank were collected. BBC and New York Times were originated using Google and America's New bank was originated using the Rhode Island College Adams Library database. An account was created and registered for both New York Times and BBC, but not for 
America's NewsBank as this particular website was accessed through the school's database using a student log-in initially. Screenshots of articles were taken and saved on desktop folders labeled "NY Times," "BBC," and "America's NewsBank," to keep the articles organized and concise. After the screenshots were taken, each screenshot was copied and pasted on a Word document and then each article was labeled using numbering. However, when using such websites to retrieve articles there were some obstacles faced. For example, initially when using New York Times specifications were used such as typing in "\#me too movement," into the search bar and for the "Section" tab selecting "US" and for the "Sort By Relevance" tab selecting "Sort By Newest." Unfortunately, when using these specifications it did not generate articles for the \#metoo movement, but generated articles for the Coronavirus or the Black Lives Matter Movement, there were only a handful of articles related to the \#metoo movement. As a result, it was decided to take out all specifications and just search "\#metoo movement," which generated an array of articles specifically related to the topic chronologically. One-hundred and fifty articles from the New York Times were screenshotted and placed in the desktop folder labeled "NY Times," which would later be transferred to a Word document to be numbered.

For the Rhode Island College Adams Library database, it is mandatory to log-in with your school access in order to browse the selection. When using America's NewsBank, an account did not need to be created or registered as it is attached to the school's database and student's log-in access. To find relevant articles, "\#metoo movement," was typed into the search bar, with specifications such as "Lead By First Paragraph," and selecting, "USA," for relevancy and narrowing the search down by selecting "Newspapers." Initially when searching this topic instead of selecting "Lead By First Paragraph," another specification was chosen called "Headline," which resulted in some articles not related to the topic. As a result, it was decided 
that "Lead By First Paragraph," generated relevant and concise articles related to the search, “\#metoo movement." A list was then generated of relevant topics, which were then screenshotted and placed in the folder, "America's News." A more concise "Current Selections" list was also screenshotted along with the one-hundred and fifty articles, but both are the same articles.

Lastly, for BBC, this seemed to be the more difficult site as you cannot include specifications for relevancy or detailed sections. Accessing BBC through Google and creating and registering for an account, "\#metoo movement," was put into the search bar, which generated both articles and short video clips that were not in chronological order. However, BBC can be accessed on other platforms such as an iPad or iPhone, but cannot be downloaded on a desktop. The BBC application was downloaded on an iPhone, without an option to use your login credentials. When searching for the "\#metoo movement," no results generated on the application, however it was decided that instead of using "movement," that using "campaign," would be a better option. As a result, "\#metoo campaign," was used in the search bar, which generated articles related to the topic in chronological order. No other specifications were used on this BBC application. One-hundred and fifty articles were needed for each website used, but the BBC mobile application only generated twenty articles. As a result, the researcher resorted back to the BBC website through Google and searched for "\#metoo campaign," even though the website does not generate articles chronologically. Through this search, only a total of onehundred and thirty-seven articles were generated. Another alternative used was to search for “\#metoo movement.” The articles were not in chronological order, but generated a sample of articles over one-hundred and fifty over the latter search option. In conclusion, it was decided that using "\#metoo movement," in the search bar was a better alternative and the researcher would have to arrange the one-hundred and fifty articles chronologically by hand from most 
recent to oldest. The research highlighted each year in a different color, in which she would write down the dates and order them from most recent to oldest on a sheet of paper. After rearranging the date correctly, the researcher would arrange them on a Word document to make it more concise. After the researcher organizes the one-hundred and fifty BBC articles, then the articles would be grouped according to the research randomizer sample numbers in order to complete the analysis.

Using a system called Research Randomizer, a sample of fifty articles from each of the websites: BBC, New York Times, and America's NewsBank will be selected for qualitative and quantitative analyses. Research Randomizer is accessed using Google. In order to generate a list, Research Randomizer will ask specific questions. For this particular research topic, the website asks “How Many Sets of Numbers Do You Want to Generate?" The researcher selected the number three as there are three websites used: BBC, New York Times, and America's NewsBank. When asked "How many numbers per set?" The number fifty was selected as the total sample size of one-hundred and fifty. For the "Number Range," one through one-hundred and fifty were typed in. When asked "Do You Wish Each Number in a Set to Remain Unique?" The researcher selected "Yes." When asked, "Do You Wish to Sort the Numbers that are Generated?" The researcher selected, "Yes, least to greatest," in order to keep the numbering concise and in an order. Lastly, the website asked, "How Do You Wish to View Your Random Numbers?" The researcher selected, "Place Markers Off.” As a result, a list of numbers was generated for each sample set (refer to Appendix for list of unique numbers). 


\section{QUANTITATIVE CODING}

During the quantitative section of this paper, both independent and dependent variables will be examined. The independent variables (causes) are the factors impacting news coverage such as: source of publication (national and international); region of publication in a national context: Northeast, South, Midwest, West, Northcentral; region of publication in an international context: Europe, Asia, Africa, Australia, North America and South America; intended audience of publication by region (local, national or international); types of intended audience: general news-readers, specific readership other survivors, or specific readership movement supports; time of publication: less than one year, one less than two, or more than 2 years; news classification: regular news, opinion, politics, business, entertainment/arts, lifestyle/leisure, science and technology and medicine; visuals (visuals included or not included); types of visuals: pictures, graphs or videos; author (known or unknown); gender of author (male, female, unknown/non-binary/listed as staffed); race of author (white, non-white, unknown); number of officials and celebrities, ordinary people, identifiable perpetrators, identifiable survivors; male and female perpetrators (yes or no); male and female targets/survivors/victims (yes or no); includes minors as victims and perpetrators (yes or no); types of overall victimization: mental/emotional, physical, vicarious, and financial; types of sexual victimization: sexual harassment/non-physical, sexual assault, rape, and gender discrimination/sexism; legal status of case: sentenced, under trail, under investigation, appeal, accusation with no legal repercussion, lawsuit, and defamation (Refer to Table One: Quantitative Variables to see the list of codes used in the SPSS system). 
The dependent variable (effects) is the representation of the \#MeToo movement in the news articles, specifically newspapers and the positive \#MeToo coverage, negative \#MeToo coverage and neutral coverage. Refer to Table One: Quantitative Variables to see the list of codes used in the SPSS system.

TABLE ONE. QUANTITATIVE VARIABLES

\begin{tabular}{|c|c|}
\hline INDEPENDENT VARIABLES & \\
\hline Source of Publication & $\begin{array}{l}\text { National (1) } \\
\text { International (2) }\end{array}$ \\
\hline Region of Publication (National) & $\begin{array}{l}\text { Northeast (1) } \\
\text { South (2) } \\
\text { Midwest (3) } \\
\text { West (4) } \\
\text { Northcentral (5) }\end{array}$ \\
\hline Region of Publication (International) & $\begin{array}{l}\text { Europe (1) } \\
\text { Asian (2) } \\
\text { African (3) } \\
\text { Australian (4) } \\
\text { North American (5) } \\
\text { South American (6) }\end{array}$ \\
\hline Intended Audience of Publication by Region & $\begin{array}{l}\text { Local (1) } \\
\text { National (2) } \\
\text { International (3) }\end{array}$ \\
\hline Types of Intended Audience & $\begin{array}{l}\text { General News-Readers (1) } \\
\text { Specific Readership Other Survivors (2) } \\
\text { Specific Readership Movement Supporters (3) }\end{array}$ \\
\hline Time of Publication & $\begin{array}{l}\text { Less Than One Year (1) } \\
1 \text { Less Than } 2 \text { (2) } \\
\text { More Than } 2 \text { Years ( } 3)\end{array}$ \\
\hline News Classification & $\begin{array}{l}\text { Regular News (1) } \\
\text { Opinion (20) } \\
\text { Politics (3) } \\
\text { Business (4) } \\
\text { Entertainment/Arts (5) } \\
\text { Lifestyle/Leisure (6) } \\
\text { Science And Technology (7) } \\
\text { Medicine (8) }\end{array}$ \\
\hline Visuals & Visuals Included (1) \\
\hline
\end{tabular}




\begin{tabular}{|c|c|}
\hline & Visuals Not Included (2) \\
\hline Types of Visuals & $\begin{array}{l}\text { Pictures (1) } \\
\text { Graphs (2) } \\
\text { Videos (3) }\end{array}$ \\
\hline Author & $\begin{array}{l}\text { Known (1) } \\
\text { Unknown/Not Specified/Listed As Staffed (2) }\end{array}$ \\
\hline Gender of Author & $\begin{array}{l}\text { Male (1) } \\
\text { Female (2) } \\
\text { Unknown/Non-Binary/Listed As Staffed (3) }\end{array}$ \\
\hline Race of Author & $\begin{array}{l}\text { White (1) } \\
\text { Non-Whites (2) } \\
\text { Unknown (3) }\end{array}$ \\
\hline \multicolumn{2}{|l|}{ Number of officials/Celebrities } \\
\hline \multicolumn{2}{|l|}{ Number of Ordinary People } \\
\hline \multicolumn{2}{|l|}{ Number of Identifiable Perpetrators } \\
\hline \multicolumn{2}{|l|}{ Number of Identifiable Survivors } \\
\hline Male Perpetrators & $\begin{array}{l}\text { Yes (1) } \\
\text { No (2) }\end{array}$ \\
\hline Female Perpetrators & $\begin{array}{l}\text { Yes (1) } \\
\text { No (2) }\end{array}$ \\
\hline Male Target & $\begin{array}{l}\text { Yes (1) } \\
\text { No (2) }\end{array}$ \\
\hline Female Target & $\begin{array}{l}\text { Yes (1) } \\
\text { No (2) }\end{array}$ \\
\hline Includes Minors As Victims & $\begin{array}{l}\text { Yes (1) } \\
\text { No (2) }\end{array}$ \\
\hline Includes Minors As Perpetrators & $\begin{array}{l}\text { Yes (1) } \\
\text { No (2) }\end{array}$ \\
\hline Types of Overall Victimization & $\begin{array}{l}\text { Mental/Emotional (1) } \\
\text { Physical (2) } \\
\text { Vicarious (3) } \\
\text { Financial (4) }\end{array}$ \\
\hline Type of Sexual Victimization & $\begin{array}{l}\text { Sexual Harassment/Non-Physical (1) } \\
\text { Sexual Assault (2) } \\
\text { Rape (3) } \\
\text { Gender Discrimination/Sexism (4) }\end{array}$ \\
\hline Legal Status of Case & $\begin{array}{l}\text { Sentenced (1) } \\
\text { Under Trial (2) } \\
\text { Under Investigation (3) }\end{array}$ \\
\hline
\end{tabular}




\begin{tabular}{|l|l|}
\hline & $\begin{array}{l}\text { Appeal (4) } \\
\text { Accusation With No Legal Repercussion (5) Lawsuit (6) } \\
\text { Defamation (7) }\end{array}$ \\
\hline DEPENDENT VARIABLE & \\
\hline Treatment & $\begin{array}{l}\text { News (1) } \\
\text { Feature (2) } \\
\text { Commentary/Criticism (3) } \\
\text { Other (4) }\end{array}$ \\
\hline Tone of Commentary & $\begin{array}{l}\text { Negative/Critical (1) } \\
\text { Positive/Non-Critical (2) } \\
\text { Neutral (3) }\end{array}$ \\
\hline
\end{tabular}

\section{QUALITATIVE CODING}

For qualitative coding guidelines from The African Journal of Emergency Medicine, $A$ hands-on guide to doing content analysis (Erlingsson and Brysiewicz 2017), were followed. The goal is to organize the information gathered into concise summary units. As a result, you will end up with categories, sub-categories and themes to break down the information examined. Initially, you start with main points of the text in which you start to divide the main points into smaller parts, called meaning units. After gathering the meaning units, you are able to condense those units into codes which turn into categories, sub-categories, and an overall theme. Formulating categories allows the researcher to reflect on the analysis in new ways. A category answers the: Who, what, when, where, and why. It is important to make sure the categories and sub-categories make sense together. Making adjustments is important as you want your analysis to fit together; like a puzzle. It is also important to conduct your analysis in a non-bias way and to explore other new perspectives to help your data. Refer to Appendix D-F, for a list of Meaning Units, Condensed Meaning Units, and Codes with Sub-Codes and Subsequent Themes. 


\section{QUANTITATIVE FINDINGS}

In this section of the paper the percentages associated with the independent and dependent variables will be discussed as well as the results from the Chi-Square test of significance which examined select hypotheses as mentioned above in the Quantitative Hypotheses section of the research paper.

TABLE TWO. DESCRIPTIVE SUMMARY OF INDEPENDENT AND DEPENDENT VARIABLES

\begin{tabular}{|c|c|c|c|}
\hline VARIABLES & CATEGORIES & FREQUENCIES & $\begin{array}{l}\text { VALID } \\
\text { PERCENTAGES }\end{array}$ \\
\hline $\begin{array}{l}\text { Source of } \\
\text { Publication }\end{array}$ & $\begin{array}{l}\text { National (1) } \\
\text { International (2) }\end{array}$ & $\begin{array}{l}100 \\
50\end{array}$ & $\begin{array}{l}66.7 \\
33.3\end{array}$ \\
\hline $\begin{array}{l}\text { Region of } \\
\text { Publication } \\
\text { (National) }\end{array}$ & $\begin{array}{l}\text { Northeast (1) } \\
\text { South (2) } \\
\text { Midwest (3) } \\
\text { West (4) } \\
\text { Northcentral (5) }\end{array}$ & $\begin{array}{l}75 \\
7 \\
11 \\
6 \\
1\end{array}$ & $\begin{array}{l}75.0 \\
7.0 \\
11.0 \\
6.0 \\
1.0\end{array}$ \\
\hline $\begin{array}{l}\text { Region of } \\
\text { Publication } \\
\text { (International) }\end{array}$ & $\begin{array}{l}\text { Europe (1) } \\
\text { Asian (2) } \\
\text { African (3) } \\
\text { Australian (4) } \\
\text { North American (5) } \\
\text { South American (6) }\end{array}$ & $\begin{array}{l}37 \\
5 \\
1 \\
0 \\
7 \\
0\end{array}$ & $\begin{array}{l}74.0 \\
10.0 \\
2.0 \\
0 \\
14.0 \\
0\end{array}$ \\
\hline $\begin{array}{l}\text { Intended } \\
\text { Audience of } \\
\text { Publication by } \\
\text { Region }\end{array}$ & $\begin{array}{l}\text { Local (1) } \\
\text { National (2) } \\
\text { International (3) } \\
\text { Combined (4) } \\
\text { Local and National } \\
\text { National and } \\
\text { International }\end{array}$ & $\begin{array}{l}34 \\
0 \\
27 \\
12 \\
54 \\
23\end{array}$ & $\begin{array}{l}22.7 \\
0 \\
18.0 \\
8.0 \\
36.0 \\
15.3\end{array}$ \\
\hline $\begin{array}{l}\text { Types of Intended } \\
\text { Audience }\end{array}$ & $\begin{array}{l}\text { General News-Readers } \\
\text { (1) } \\
\text { Specific Readership } \\
\text { Other Survivors (2) }\end{array}$ & $\begin{array}{l}44 \\
1 \\
3 \\
41\end{array}$ & $\begin{array}{l}29.3 \\
.7 \\
2.0 \\
27.3\end{array}$ \\
\hline
\end{tabular}




\begin{tabular}{|c|c|c|c|}
\hline & $\begin{array}{l}\text { Specific Readership } \\
\text { Movement Supporters } \\
(3) \\
\text { Combined (4) } \\
\text { General News-Readers } \\
\text { and Other Survivors } \\
\text { General News-Readers } \\
\text { and Movement } \\
\text { Supporters } \\
\text { Other Survivors and } \\
\text { Movement Supporters }\end{array}$ & $\begin{array}{l}10 \\
4 \\
47\end{array}$ & $\begin{array}{l}6.7 \\
2.7 \\
31.3\end{array}$ \\
\hline $\begin{array}{l}\text { Time of } \\
\text { Publication }\end{array}$ & $\begin{array}{l}\text { Less Than One Year (1) } \\
1 \text { Less Than } 2 \text { (2) } \\
\text { More Than } 2 \text { Years (3) }\end{array}$ & $\begin{array}{l}112 \\
15 \\
23\end{array}$ & $\begin{array}{l}74.7 \\
10.0 \\
15.3\end{array}$ \\
\hline $\begin{array}{l}\text { News } \\
\text { Classification }\end{array}$ & $\begin{array}{l}\text { Regular News (1) } \\
\text { Opinion (20) } \\
\text { Politics (3) } \\
\text { Business (4) } \\
\text { Entertainment/Arts (5) } \\
\text { Lifestyle/Leisure (6) } \\
\text { Science And } \\
\text { Technology (7) } \\
\text { Medicine (8) } \\
\text { Opinion and Politics } \\
\text { Opinion and } \\
\text { Entertainment/Arts } \\
\text { Politics and Business } \\
\text { Politics and } \\
\text { Entertainment/Arts } \\
\text { Politics and Science and } \\
\text { Technology } \\
\text { Business and Science } \\
\text { and Technology } \\
\text { Entertainment/Arts and } \\
\text { Lifestyle/Leisure } \\
\text { Science and } \\
\text { Technology and } \\
\text { Medicine }\end{array}$ & $\begin{array}{l}42 \\
30 \\
17 \\
5 \\
45 \\
2 \\
0 \\
0 \\
1 \\
1 \\
2 \\
1 \\
1 \\
1 \\
1 \\
1 \\
1\end{array}$ & $\begin{array}{l}28.0 \\
20.0 \\
11.3 \\
3.3 \\
30.0 \\
1.3 \\
0 \\
0 \\
.7 \\
.7 \\
1.3 \\
.7 \\
.7 \\
.7 \\
.7 \\
.7\end{array}$ \\
\hline Visuals & $\begin{array}{l}\text { Visuals Included (1) } \\
\text { Visuals Not Included } \\
\text { (2) }\end{array}$ & $\begin{array}{l}51 \\
99\end{array}$ & $\begin{array}{l}34.0 \\
66.0\end{array}$ \\
\hline Types of Visuals & $\begin{array}{l}\text { Pictures (1) } \\
\text { Graphs (2) } \\
\text { Videos (3) } \\
\text { Combined (4) } \\
\text { Pictures and Videos } \\
\text { Graphs and Videos }\end{array}$ & $\begin{array}{l}53 \\
0 \\
32 \\
1 \\
12 \\
1\end{array}$ & $\begin{array}{l}53.5 \\
0 \\
32.3 \\
1.0 \\
12.1 \\
1.0\end{array}$ \\
\hline Author & Known (1) & $\begin{array}{l}106 \\
44\end{array}$ & $\begin{array}{l}70.7 \\
29.3\end{array}$ \\
\hline
\end{tabular}




\begin{tabular}{|c|c|c|c|}
\hline & $\begin{array}{l}\text { Unknown/Not } \\
\text { Specified/Listed As } \\
\text { Staffed (0) }\end{array}$ & & \\
\hline Gender of Author & $\begin{array}{l}\text { Male (1) } \\
\text { Female (2) } \\
\text { Unknown/Non- } \\
\text { Binary/Listed As } \\
\text { Staffed (0) } \\
\text { Multiple } \\
\text { Authors/Genders } \\
\text { Combined (3) }\end{array}$ & $\begin{array}{l}29 \\
51 \\
\\
45 \\
25\end{array}$ & $\begin{array}{l}19.3 \\
34.0 \\
30.0 \\
16.7\end{array}$ \\
\hline Race of Author & $\begin{array}{l}\text { White (1) } \\
\text { Non-Whites (2) } \\
\text { Unknown (0) } \\
\text { Others/Combined/Auth } \\
\text { ors Unknown (3) }\end{array}$ & $\begin{array}{l}60 \\
15 \\
50 \\
\\
\\
25\end{array}$ & $\begin{array}{l}40.0 \\
10.0 \\
33.3 \\
\\
16.7\end{array}$ \\
\hline $\begin{array}{l}\text { Number of } \\
\text { officials/Celebriti } \\
\text { es (Recoded) }\end{array}$ & $\begin{array}{l}\text { No Celebrities in } \\
\text { Articles } \\
\text { Mention of Celebrities } \\
\text { in Articles }\end{array}$ & $\begin{array}{l}21 \\
129\end{array}$ & $\begin{array}{l}14.0 \\
86.0\end{array}$ \\
\hline Male Perpetrators & $\begin{array}{l}\text { Yes (1) } \\
\text { No (2) }\end{array}$ & $\begin{array}{l}113 \\
37\end{array}$ & $\begin{array}{l}75.3 \\
24.7\end{array}$ \\
\hline $\begin{array}{l}\text { Female } \\
\text { Perpetrators }\end{array}$ & $\begin{array}{l}\text { Yes (1) } \\
\text { No (2) }\end{array}$ & $\begin{array}{l}0 \\
150\end{array}$ & $\begin{array}{l}0 \\
100.0\end{array}$ \\
\hline Male Target & $\begin{array}{l}\text { Yes (1) } \\
\text { No (2) }\end{array}$ & $\begin{array}{l}1 \\
149\end{array}$ & $\begin{array}{l}.7 \\
99.3\end{array}$ \\
\hline Female Target & $\begin{array}{l}\text { Yes (1) } \\
\text { No (2) }\end{array}$ & $\begin{array}{l}98 \\
52\end{array}$ & $\begin{array}{l}65.3 \\
34.7\end{array}$ \\
\hline $\begin{array}{l}\text { Includes Minors } \\
\text { As Victims }\end{array}$ & $\begin{array}{l}\text { Yes (1) } \\
\text { No (2) }\end{array}$ & $\begin{array}{l}25 \\
125\end{array}$ & $\begin{array}{l}16.7 \\
83.3\end{array}$ \\
\hline $\begin{array}{l}\text { Includes Minors } \\
\text { As Perpetrators }\end{array}$ & $\begin{array}{l}\text { Yes (1) } \\
\text { No (2) }\end{array}$ & $\begin{array}{l}0 \\
150\end{array}$ & $\begin{array}{l}0 \\
100.0\end{array}$ \\
\hline $\begin{array}{l}\text { Types of Overall } \\
\text { Victimization }\end{array}$ & $\begin{array}{l}\text { Mental/Emotional (1) } \\
\text { Physical (2) } \\
\text { Vicarious (3) } \\
\text { Financial (4) } \\
\text { Combined (5) }\end{array}$ & $\begin{array}{l}3 \\
2 \\
0 \\
1 \\
146\end{array}$ & $\begin{array}{l}2.0 \\
1.3 \\
0 \\
.7 \\
96.1\end{array}$ \\
\hline $\begin{array}{l}\text { Type of Sexual } \\
\text { Victimization }\end{array}$ & $\begin{array}{l}\text { Sexual } \\
\text { Harassment/Non- } \\
\text { Physical (1) } \\
\text { Sexual Assault (2) } \\
\text { Rape (3) }\end{array}$ & $\begin{array}{l}6 \\
29 \\
3 \\
4\end{array}$ & $\begin{array}{l}5.4 \\
25.9 \\
2.7 \\
3.6\end{array}$ \\
\hline
\end{tabular}




\begin{tabular}{|c|c|c|c|}
\hline & $\begin{array}{l}\text { Gender } \\
\text { Discrimination/Sexism } \\
\text { (4) } \\
\text { Sexual Harassment/Non } \\
\text { Physical and Sexual } \\
\text { Assault } \\
\text { Sexual Assault and } \\
\text { Rape } \\
\text { Sexual } \\
\text { Harassment/Non- } \\
\text { Physical and Sexual } \\
\text { Assault and Rape }\end{array}$ & $\begin{array}{l}22 \\
29 \\
\\
19\end{array}$ & $\begin{array}{l}19.6 \\
25.9 \\
17.0\end{array}$ \\
\hline $\begin{array}{l}\text { Legal Status of } \\
\text { Case }\end{array}$ & $\begin{array}{l}\text { Sentenced (1) } \\
\text { Under Trial (2) } \\
\text { Under Investigation (3) } \\
\text { Appeal (4) } \\
\text { Accusation With No } \\
\text { Legal Repercussion (5) } \\
\text { Lawsuit (6) } \\
\text { Defamation (7) } \\
\text { Sentenced and Under } \\
\text { Investigation } \\
\text { Sentenced and Appeal } \\
\text { Sentenced and } \\
\text { Accusation with No } \\
\text { Legal Repercussion } \\
\text { Under Trial and Under } \\
\text { Investigation } \\
\text { Under Investigation and } \\
\text { Accusation with No } \\
\text { Legal Repercussion } \\
\text { Under Investigation and } \\
\text { Lawsuit } \\
\text { Accusation with No } \\
\text { Legal Repercussion and } \\
\text { Lawsuit } \\
\text { Sentenced and Under } \\
\text { Investigation and } \\
\text { Accusation with No } \\
\text { Legal Repercussion } \\
\text { Appeal and Accusation } \\
\text { with No Legal } \\
\text { Repercussion and } \\
\text { Lawsuit and } \\
\text { Defamation } \\
\text { Otherwise } \\
\text { Under Investigation and } \\
\text { Under Trial }\end{array}$ & $\begin{array}{l}25 \\
4 \\
5 \\
0 \\
14 \\
0 \\
0 \\
2 \\
12 \\
2 \\
1 \\
21 \\
1 \\
1 \\
\\
143 \\
9 \\
2 \\
2 \\
\end{array}$ & $\begin{array}{l}27 / 2 \\
4.3 \\
5.4 \\
15.2 \\
0 \\
0 \\
2.2 \\
13.0 \\
2.2 \\
1.1 \\
22.8 \\
1.1 \\
1.1 \\
\\
\\
2.2 \\
94.1 \\
5.9\end{array}$ \\
\hline $\begin{array}{l}\text { DEPENDENT } \\
\text { VARIABLE }\end{array}$ & & & \\
\hline Treatment & News (1) & 57 & 38.0 \\
\hline
\end{tabular}




\begin{tabular}{|l|l|l|l|}
\hline & Feature (2) & 23 & 15.3 \\
& Commentary/Criticism & 64 & 42.7 \\
& $(3)$ & 6 & 4.0 \\
& Other (4) & & \\
\hline Tone of & Negative/Critical (1) & 66 & 44.0 \\
Commentary & Positive/Non-Critical & 25 & 16.7 \\
& (2) & 59 & 39.3 \\
& Neutral (3) & & \\
\hline
\end{tabular}

For the Source of Publication, it appears that one-hundred newspaper articles took place in the National region with 66.7 percent while only fifty newspaper articles took place in the International region with 33.3 percent. Valid percentages are explained because it excludes missing data in the sample set. It is the proportion sample that is considered valid.

For the Region of Publication (National), it appears that seventy-five newspaper articles took place in the Northeast region with 75.0 percent, the South appeared in seven articles with 7.0 percent, the Midwest appeared in eleven articles with 11 percent, the West appeared in six articles with 6 percent, and Northcentral appeared in one article with 1 percent. It was at the researcher's discretion which region would be considered: Northeast, South, Midwest, West, and Northcentral. It was chosen that Northeast would consist of the following states: Connecticut, Delaware, Maine, Massachusetts, Maryland, New Hampshire, New Jersey, New York, Pennsylvania, Rhode Island, Vermont (major cities include: New York City, Philadelphia, Boston, Baltimore and Washington D.C.). The South would consist of: Alabama, Arkansas, Florida, Georgia, Kentucky, Louisiana, Mississippi, North Carolina, Oklahoma, South Carolina, Tennessee, Texas, Virginia, and West Virginia. The Midwest would consist of: Illinois, Indiana, Kansas, Michigan, Missouri, and Ohio. The West would consist of: Alaska, Arizona, California, Hawaii, Idaho, Montana, Nevada, New Mexico, Oregon, Utah, Washington, and Wyoming. 
Lastly, Northcentral would consist of: North Dakota, Minnesota, South Dakota, Iowa, Nebraska, and Wisconsin. A Google map was also used to determine the decisions for the specific regions.

For the Region of Publication (International), it appears that thirty-seven newspaper articles took place in Europe with 74.0 percent, Asian region appeared in five articles with 10 percent, African region appeared in one article with 2 percent, the North American region appeared in seven newspaper articles with 14.0 percent, and the Australian and South American regions did not appear in the articles.

For the Intended Audience of Publication by Region, it appears that thirty-four newspaper articles took place in the Local region with 22.7 percent, the National region did not appear in the newspaper articles, the International region appeared in twenty-seven newspaper articles with 18.0 percent, a Combined category appeared in twelve newspaper articles with 8.0 percent, Local and National appeared in fifty-four newspaper articles with 36.0 percent, and National and International appeared in twenty-three newspaper articles with 15.3 percent. The category Combined means that it was considered Local, National and International. For example, in a New York Times article, 'I Felt Defenseless': Seoul Mayor's Secretary Speaks Out About Alleged Abuse, since the publication is based in New York and New York and New York Times is considered extremely diverse and popular it was decided that it could be Local and National. But because the publication was about a mayor in Seoul it was decided that it could also be International.

For the Type of Intended Audience, it appears that forty-four newspaper articles pertained to General News-Readers with 29.3 percent, Specific Readership Other Survivors appeared in one newspaper article with .7 percent, Specific Readership Movement Supporters appeared in 
three newspaper articles with 2.0 percent, General News-Readers and Specific Readership Other Survivors appeared in ten newspaper articles with 6.7 percent, General News-Readers and Specific Readership Movement Supporters appeared in four newspaper articles with 2.7 percent, and Specific Readership Other Survivors and Specific Readership Movement Supporters appeared in forty-seven newspaper articles with 31.3 percent. It was decided to come up with three basic but specific categories for readership: General News-Readers, Specific Readership Other Survivors, and Specific Readership Movement Supporters. Again, some newspaper publication readership could be considered Combined: General News-Readers, Specific Readership Other Survivors, and Specific Readership Movement Supporters.

For the Time of Publication, it appears that one-hundred and twelve newspaper articles were published Less Than One Year with 74.7 percent, newspaper articles published in 1 Less Than 2 Years appeared in fifteen articles with 10.0 percent, and newspaper articles published More Than 2 Years appeared in twenty-three articles with 15.3 percent.

For the News Classification, it appears forty-two newspaper articles were categorized as Regular News with 28.0 percent, thirty newspaper articles were categorized as Opinion with 20.0 percent, seventeen newspaper articles were categorized as Politics with 11.3 percent, five newspaper articles were categorized as Business with 3.3 percent, forty-five newspaper articles were categorized as Entertainment/Arts with 30.0 percent, two newspaper articles were categorized as Lifestyle/Leisure with 1.3 percent, Science and Technology and Medicine did not appear in the articles alone but were combined with other news types. Opinion and Politics were categorized in only one newspaper article with .7 percent, Opinion and Entertainment/Arts were categorized in one newspaper article with .7 percent, Politics and Business were categorized in two newspaper articles with 1.3 percent, Politics and Entertainment/Arts were categorized in one 
newspaper articles with .7 percent, Politics and Science and Technology were categorized in one newspaper article with .7 percent, Business and Science and Technology were categorized in one newspaper article with .7 percent, Entertainment/Arts and Lifestyle/Leisure were categorized in one newspaper article with .7 percent, and Science and Technology and Medicine were categorized in one newspaper article with .7 percent. It was decided that there could be many themes for each newspaper publication: Regular News, Opinion, Politics, Business, Entertainment/Arts, Lifestyle/Leisure, Science and Technology, and Medicine. After analyzing each newspaper publication it was determined that some publications could fall under more than one news classification or news type.

For the Visuals, it appears that fifty-one newspaper articles had visuals with 34.0 percent and ninety-nine newspaper articles did not have visuals with 66.0 percent. For the Types of Visuals it appears that fifty-three of newspaper articles had Pictures with 53.5 percent, thirty-two newspaper articles had Videos with 32.3 percent, Graphs were not displayed alone but with other types of visuals, Combined appeared in one newspaper article with 1.0 percent, Pictures and Videos appeared in twelve newspaper articles with 12.1 percent and Graphs and Videos appeared in one newspaper article with 1.0 percent. It was decided that another category called Combined be created as some newspaper publications consisted of all three: Pictures, Graphs, and Videos.

For Author, it appears that one-hundred and six authors appeared in the newspaper articles with 70.7 percent while Unknown/Not Specified/Listed as Staffed appeared only in fortyfour newspaper articles with 29.3 percent. For the Gender of Author, it appears that twenty-nine Male authors were identified with 19.3 percent, fifty-one Female authors were identified with 34.0 percent, forty-five Unknown/Non-Binary/Listed as Staffed authors were identified with 30.0 percent, and twenty-five Multiple Authors/Genders Combined were identified with 16.7 percent. 
For the Race of Author, it appears that there were sixty White authors with 40.0 percent, fifteen Non-White authors with 10.0 percent, and fifty Unknown authors with 33.3\%.

For the Number of Officials and Celebrities, it appears that twenty-one newspaper articles did not mention celebrities or officials with 14.0 percent and one-hundred twenty-nine newspaper articles did mention celebrities and officials with 86.0 percent. For Male Perpetrators, there were one-hundred and thirteen newspaper articles that mentioned male perpetrators with 75.3 percent and thirty-seven newspaper articles did not mention male perpetrators with 24.7 percent. For Female Perpetrators, one-hundred and fifty newspaper articles did not mention female perpetrators with 100.0 percent. For Male Target, only one newspaper article mentioned a male survivor/victim with .7 percent and one-hundred and fortynine newspaper articles did not mention a male survivor/victim with 99.3 percent. The only male survivor/victim mentioned was George Floyd, but he died while being detained by police officials. For Female Target, ninety-eight newspaper articles mentioned female survivors/victims with 65.3 percent and fifty-two newspaper articles did not mention female survivors/victims with 34.7 percent. However, after analyzing the newspaper publications further it was noted that some survivors had not survived and were unfortunately killed or murdered, which coined the word Victims to follow along with Survivors. For the variable Includes Minors as Victims, twenty-five newspaper articles did mention minors as victims with 16.7 percent and one-hundred and twentyfive newspaper articles did not mention minors as victims with 88.3 percent. The only two individuals who were mentioned throughout the majority of the sample size, which were included in the Minors as Victims table were Dylan Farrow and Christine Blasey Ford and other unidentified girls or women. For the variable, Includes Minors as Perpetrators, one-hundred and fifty newspaper articles did not mention minors as perpetrators with 100.0 percent. 
For the Types of Overall Victimization, only three newspaper articles mentioned Mental/Emotional victimization with 2.0 percent, two newspaper articles mentioned Physical victimization with 1.3 percent, and one-hundred and forty-six newspaper articles mentioned Combined victimization which includes: Mental/Emotional, Physical, Vicarious, and Financial with 96.1 percent.

For the Type of Sexual Victimization, six newspaper articles mentioned Sexual Harassment/Non-Physical victimization with 5.4 percent, twenty-nine newspaper articles mentioned Sexual Assault with 25.9 percent, three articles mentioned Rape with 2.7 percent, four newspaper articles mentioned Gender Discrimination/Sexism with 3.6 percent, twenty-two newspaper articles mentioned Sexual Harassment/Non-Physical and Sexual Assault with 19.6 percent, twenty-nine newspaper articles mentioned Sexual Assault and Rape with 25.9 percent, nineteen newspaper articles mentioned Sexual Harassment/Non-Physical and Sexual Assault and Rape victimization with 17.0 percent.

For the Legal Status of Case, nine newspaper articles mentioned Under Investigation or Under Trial with 5.9 percent and one-hundred and forty-three newspaper articles mentioned Otherwise, which includes: Sentenced, Appeal, Accusation with No Legal Repercussion, Lawsuit and Defamation. In the Legal Status of Case section, categories were created such as: Sentenced, Under Trial, Under Investigation, Appeal, Accusation with No Legal Repercussion, Lawsuit and Defamation. Lawsuit and Defamation were added after the initial review of the newspaper publications. Some articles mentioned how women were being sued for defamation due to speaking out against their abuser. There are many categories in this table because newspaper publications mentioned more than one legal status of the perpetrator. For example, Harvey Weinstein was sentenced, but his lawyers plan to appeal his conviction. In a New York Times 
article, They Said \#MeToo. Now They Are Being Sued, it mentioned that in Beijing, China men can sue women for defamation who accuse them of abuse and in most cases the men end up winning the lawsuit with the women having to apology to their abuser and also face financial consequences for speaking out.

For the Treatment, it appears fifty-seven newspaper articles were classified as News with 38.0 percent, twenty-three newspaper articles were classified as Feature with 15.3 percent, sixtyfour newspaper articles were classified as Commentary/Criticism with 42.7 percent, and six newspaper articles were classified as Other with 4.0 percent. For the Tone of Commentary, it appears that sixty-six newspaper articles had a Negative/Critical tone with 44.0 percent, twentyfive newspaper articles has a Positive/Non-Critical tone with 16.7 percent, and fifty-nine newspaper articles had a Neutral tone with 39.3 percent.

It was at the researcher's discretion when considering what individual would be labeled as a celebrity, official, or ordinary. It was decided that if newspaper publications just listed generic names such as lawyers/prosecutors, men/women, producers/directors, professors/teachers, colleges/universities, activists/feminists, doctors, police/ students, teens, jury, voters, authors/editors/journalists, family members of survivors and perpetrators, TV anchors, and directors/presidents of organizations/clubs that they would be labeled as Ordinary. For example, the researcher considered names such as Harvey Weinstein, Bill Cosby, Woody Allen, Christine Blasey Ford, Brett Kavanaugh, R.Kelly, Donald Trump, Tara Reader, Joe Biden as Celebrities/Officials.

Additionally few other variables measured were also measured at ratio levels. These variables include number of identifiable celebrities in articles, number of ordinary people, number of perpetrators and number of victims . Descriptive statistics were also ran for the 
variables and following are the modal categories (categories with highest representations for each of the variables): most newspapers mentioned either one(18\%) or two (16\%) celebrities. Additionally, $86.5 \%$ of newspapers mentioned ordinary people as well. $40 \%$ of publications reported one identifiable perpetrator while $34 \%$ of newspapers did not report an identifiable survivor (Variables not in Table, Refer to Appendix B)

In the following sections partial cross-tabulations results depicting row percentages for critical /negative tone of reporting of select independent variables are inserted. These test the association between select independent variables (Hypotheses One through Seven)

Chi-square ultimately test the significance between categorical variables in the same population (Also refer to Appendix B: Charts summarizing bivariate associations between Independent and Dependent Variables - )

Table Three. Partial Cross-Tabulations Results Depicting Row Percentages For Critical /Negative Tone Of Reporting Of Select Independent Variables

\begin{tabular}{|c|c|c|c|}
\hline & & Critical/Negative & Chi Square \\
\hline \multicolumn{4}{|l|}{ Gender } \\
\hline & Unknown & $24.2 \%$ & $19.446^{* * *}$ \\
\hline & Male(0) & $22.7 \%$ & \\
\hline & Female(1) & $37.9 \%$ & \\
\hline & Multiple & $15.2 \%$ & \\
\hline & Total & $100.0 \%$ & \\
\hline \multicolumn{4}{|l|}{ Source } \\
\hline & National (1) & $69.7 \%$ & $4.735^{*}$ \\
\hline & International (2) & $30.3 \%$ & \\
\hline & Total & $100.0 \%$ & \\
\hline \multicolumn{4}{|c|}{ Region (National) } \\
\hline & Northeast (1) & $80.4 \%$ & $16.014 * *$ \\
\hline & South (2) & $4.3 \%$ & \\
\hline & Midwest (3) & $8.7 \%$ & \\
\hline & West (4) & $6.5 \%$ & \\
\hline & Northcentral (5) & $0.0 \%$ & \\
\hline & Total & $100.0 \%$ & \\
\hline \multicolumn{4}{|l|}{ Time } \\
\hline & Less Than One Year & $72.7 \%$ & 3.982 \\
\hline & 1 Less Than Two Years & $12.1 \%$ & \\
\hline & More Than Two Years & $15.2 \%$ & \\
\hline
\end{tabular}


Total

$100.0 \%$

Number of Officials and Celebrities

No Celebrities in Articles

$16.7 \%$

Mention of Celebrities in Articles 83.3\%

Total

$100.0 \%$

Table Three. Partial Cross-Tabulations Results Depicting Row Percentages For Critical /Negative Tone Of Reporting Of Select Independent Variables

\begin{tabular}{cc}
\hline & Critical/Nega \\
\hline Type of Overall Victimization Recoded & \\
Mental/Emotional & $1.5 \%$ \\
Physical & $1.5 \%$ \\
Financial & $0.0 \%$ \\
Combined Categories & $97.0 \%$ \\
Total & $100.0 \%$
\end{tabular}

Legal Status of Case

Otherwise

$89.4 \%$

Under Investigation and Under Trial $10.6 \%$

Total

$100.0 \%$

$5.021^{*}$

Chi Square

3.193

4.791

$* \mathrm{p} \leq .10, * * \mathrm{p} \leq .05, * * * \mathrm{p} \leq .005$

For the gender of author, the cross-tabulations suggest that 37 percent of authors identified as female, in comparison to 22 percent of authors identified as male and 24 percent of authors with unknown gender took a more critical tone when reporting about the \#MeToo movement (Amongst women authors, if we read column percentages, almost 50 percent took a critical/negative tone in reporting movement) (Chi-Square 19.466, significant at .003 level). The hypothesis was validated.

It appears that 70 percent of National media in comparison to 30.3 percent of International media took a critical role. If one examines the column percentages - within national media, 46 percent took a negative tone in comparison to 12 percent of positive tone and 42 percent who took on a neutral tone. This shows that when comparing within groups that had a negative critical tone among national media, they overall took a more critical tone. The sample 
size of higher cases of national newspaper articles was less impactful (chi square 4.73, marginally significant).

For National coverage by region, the cross-tabulations suggest that 80 percent of publication from the Northeast, in comparison to other regions of National media took a more critical tone in reporting the \#MeToo movement (Chi-Square 16.01 significant at .05 level) As you can see besides the fact that the northeastern media reached 80.4 percent in comparison to others taking a critical role, one can also examine the column percentages - amongst northeastern media 49 percent of them took a negative tone in comparison to 9.3 percent who took a positive tone and 41 percent who took on a neutral tone. What this shows is that both in terms of comparing within groups that had a negative critical tone or among northeastern media in terms of their responses, they overall took a more critical tone than their counterparts. The sample size of higher northeastern newspaper articles was less impactful). The second and third hypotheses are also validated.

In terms of time of publication, of 72.7 percent of articles which took a negative tone, were published a year back (counterintuitive to hypothesis four although the Chi Square value of 3.98, was not significant)

For celebrities-- 83.4 percent of newspaper articles which mentioned celebrities and officials in comparison to the others took a critical role. However, if we examine the column percentages amongst articles which mention celebrities, there seems to be a mix at half and half division among articles that were neutral and articles that were critical. What this demonstrates is that for the newspaper articles with celebrities in terms of their responses, the results are less conclusive although Chi-Square is marginally significant. 
For the Tone of Commentary and Types of Overall Victimization cross-tabulation and chi-square, it was discovered that there was a more critical/negative tone when reporting of the movement with Combined Categories of the types of overall victimization with 97 percent. There were more newspaper articles that mentioned combined categories of overall victimization. In this case, the chi-square of 3.193 is not significant at $p<.05$.

For the Tone of Commentary and Legal Status of Case cross-tabulation and chi-square, it was discovered that there was a more critical/negative tone when reporting of the movement with 89 percent of Otherwise, which included legal statuses such as Sentenced, Appeal, Accusation with No Legal Repercussion, Lawsuit and Defamation versus Under Investigation and Under Trial with 10 percent, with a chi-square of 4.791 . In this case, the chi-square of 4.791 is not significant.

\section{QUALITATIVE FINDINGS}

In this section, one-hundred and fifty newspaper publications were analyzed from three different newspaper sets: BBC, The New York Times, and America's NewsBank, in which brief meaning units or sentences summarizing the articles were formed in order to break down the meaning units into codes and sub-codes. After the codes and sub-codes were formulated, themes were generated to combine the meanings of each category of the codes and sub-codes. The main qualitative themes that emerged from a detailed qualitative content analysis will be discussed.

The Human Impact of the \#MeToo Movement. This theme refers to the types of overall victimization such as the codes: mental/emotional, physical, vicarious, and financial victimization. These codes refer to the types of trauma and distress the survivors/victims faced 
following their abuse and the after effects of their abuse. Many survivors/victims who spoke out against their abuse faced harsh scrutiny, backlash, and had their personal information broadcasted throughout the media. Psychological abuse which is often referred to as mental and emotional abuse can consist of exposing an individual to anxiety, depression, and post-traumatic stress. Physical victimization consists of injuries as a result of an attack or an assault. Vicarious victimization consists of trauma invoked by a person or persons. Family, friends and colleagues of people who have experienced vicarious victimization can struggle with their feelings of stress and grief. For example, the researcher considered Dylan Farrow a vicarious victimization because she alleged that she was molested by her adopted father, Woody Allen, when she was just seven-years-old. However, Woody Allen has denied the allegations. Lastly, financial victimization was calculated by determining how many individuals were affected monetarily. For example, survivors/victims were forced to take a different route with their careers due to their abuse in their current workplace or due to the abuse and scrutiny some individuals received they felt it was necessary to abandon their work and position to focus on healing and reflecting. Other survivors/victims faced severe lawsuits and financial consequences for speaking out against their abuser. According to Rainn.org, sexual abuse or violence may cause some survivors/victims to face mental/emotional, physical or mental health concerns. Some mental/emotional effects can include: anger, fear, humiliation, shame, guilt, powerlessness and loss of control, anxiety, depression, post-traumatic stress disorder, substance abuse, suicidal ideation, panic attacks, and more. Some physical effects can include: fatigue, headaches, eating and sleep disturbances, and increased stress levels.

An example of victimization would be in a New York Times article, All Bets Are Off as Harvey Weinstein's Sexual Assault Trial Opens Today (Twohey et al. 2020), states that other 
women had stories involving Weinstein, but were not prepared to face scrutiny from a criminal trial. One actress told investigators that she decided to file a lawsuit against Weinstein instead, which allowed her to remain anonymous. Many women who accused Weinstein of sexual abuse admitted to staying in contact with him even after the abuse because he was a powerful producer and feared he would ruin their careers. Harvey Weinstein, a former film producer and convicted sex offender, has faced charges consisting of first-degree criminal sexual act for forcing oral sex on Miriam "Mimi” Haleyi in 2006, first-degree rape and one charge of third-degree rape of Jessica Mann in 2013, and two predatory sexual assault charges of the alleged rape of Annabella Sciorra in 1993-1994 and alleged crimes against Haleyi and Mann. He faces twenty-three years behind bars, but his lawyers are in the process of appealing his conviction.

Combining Social Movements Around the World. This theme refers to the types of movements that have surfaced around the world. Unbeknownst to the researcher, there are many movements being formed around the world to fight for women's rights and put an end to sexual abuse and violence. The codes created were based on the different types of movements found throughout the newspaper publications: \#MeToo Movement, \#BelieveAllWomen, \#BalanceTonPorc (Expose Your Pig), \#UnDiasInNosotras (A Day Without Us), \#Woyeshi (Me Too), \#TimesUp, and \#NiUnaMeos (Not One Less). These movements were formed around the world to combat sexual abuse and violence and for women's rights to be taken into consideration and for their voices to be heard. These activists are protesting around the world for justice to be served. The Me Too or \#MeToo movement was created by Tarana Burke in 2006 in an effort to promote equality. Later in 2017, actress, Alyssa Milano took to Twitter to post, "Women who have been sexually harassed or assaulted, write \#MeToo." This soon became viral and the 
movement started to gain traction. This movement does not aim to target specific individuals, but to, but to help those survivors/victims have a voice to speak out against their abuser knowing they are not alone. The movement challenges the judicial system to make changes to the laws and policies that acknowledge sexual abuse and violence and to seek the due process and justice individuals deserve. \#BelieveAllWomen was formed when Tara Reade accused Joe Biden of sexual assault and when the founder of the MeToo movement, Tarana Burke, led a national walkout in solidarity of Ford before her testimony using the hashtag \#BelieveSurvivors. "We believe Dr. Blasey Ford. We believe survivors,” Burke took to Twitter (Honderich 2020). \#BalanceTonPorc (Expose Your Pig) was created by a journalist, Sandra Muller, when she accused a former television executive of unwanted advances. The television executive filed a defamation lawsuit against her in which she was ordered by the court to pay thousands in fines and remove the post mentioning the executive. \#BalanceTonPorc is an anti-sexism movement in a culture where unwanted advances can go unaddressed. Women in Mexico are going on strike to protest the escalated violence towards women. Women skipped work and other obligations to take to the streets protesting \#UnDiasInNosotras (A Day Without Us). This movement was formed because of the tireless acts to change the sphere of men and women. There is an unsaid rule that men can do as they please while women have to think, act, and behave a certain way. This act is known as machismo also known as toxic masculinity. Latin America faces a wave of violence as well where millions of women took a stand against gender violence protesting \#NiUnaMenos (Not One Less). The hashtag \#TimesUp is similar to the \#MeToo movement and can be considered a next-step approach that aims to make permanent change in the workplace. Its goal is to provide fairness, safety, and equity in a workplace to be enforced. \#TimesUp was founded in 2018 to combat sexual harassment. In China, a growing number of individuals are 
using defamation lawsuits to counter claims of sexual harassment and assault. The government has enacted laws banning sexual harassment but does not define the term. Enforcement is poor and defamation laws are usually in favor of the plaintiffs. The hashtags \#MeToo and \#Woyeshi (Me Too in Chinese) are banned on the Chinese internet. This movement in China is seen as a threat and attempts to prohibit political upheaval.

Despite certain countries having a strict hierarchical code, the survivors/victims still spoke out against their abuse and faced consequences such as backlash, outcasted by society, embarrassed and scrutinized. The goal for forming these movements and unions is so that other survivors/victims become courageous enough to come forward. Many of these movements were created because the survivors/victims felt that they were being silenced and made to feel ashamed of the abuse they faced.

Sexual Violence and Behaviors Can Vary. This theme refers to the types of sexual violence/victimization individuals faced. Throughout the sample size of one-hundred and fifty newspaper publications, many types of sexual violence and victimization had occurred, which resulted in these codes: sexual harassment/non-physical, sexual assault, rape, and gender discrimination/sexism. From the newspaper publications, it was observed that only women had come forward about their alleged abuse versus men. Though some of the accusations and allegations are still under investigation, these individuals who spoke out against their abuse and abuser were able to convict high-profile and elite celebrities and officials and have inspired other survivors/victims to speak out about their abuse and no longer feel the need to hide in the 
shadows. It is important to note that a majority of these survivors/victims have repressed these memories of abuse for many years and have only recently come forward.

According to Rainn.org, sexual harassment/non-physical consists of unwelcome sexual advances, requests for sexual favors and other verbal or physical harassment. Negative comments about women as a group may also be considered a form of sexual harassment. Sexual assault refers to sexual conduct or behavior, often physical that happens without the consent of the individual. Some forms of sexual assault include: penetration of the victim's body, also known as rape, attempted rape, fondling or unwanted sexual touching, and forcing an individual to perform sexual acts, such as oral sex or penetration of the perpetrator's body.

In a BBC article and short video clip, Was it 'sexual assault' or just a bad date? (2018) The question arises when an unidentified woman published an account of sexual advances while on a date with comedian, Aziz Ansari. Some feminists dismissed the incident and called it a bad date and should have remained private and others are said it opens the debate about normalizing aggressive behavior towards women.

Laws and Policies are Being Challenged in the Midst of the Movement. This theme refers to the laws and policies mentioned throughout the newspaper publications. The codes that were formed consist of: statute of limitations, school and campus policies, stereotypes, sexism, gender discrimination, Title IX, NDA's (non-disclosure agreements), equality, defamation, "prior bad act” law in New York, the judicial system, lawsuits, and strict hierarchical codes and regulations. This category refers to obstacles that victims and survivors faced when coming forth 
about their allegations and accusations. Some were not able to participate in trials due to the statute of limitations expiring or silenced by non-disclosure agreements. Some individuals were released from non-disclosure agreements and others were not able to be released. It is very risky to break a non-disclosure agreement and can result in a breach of contract and could face several financial penalties. These laws, policies, and regulations are now being challenged in the midst of the \#MeToo movement and other movements being formed around the world.

Statute of limitations is a law that sets a time limit on when individual(s) can initiate legal proceedings. However, most crimes like murder do not have a statute of limitations. Sexism and gender discrimination are a form of inequality based on a person's sex or gender, which can also be linked to stereotyping as well. Title IX is a law that was passed as part of the Education Amendments of 1972 that protects individuals from discrimination based on sex in education and activities that receive federal financial assistance. Non-disclosure agreements are contracts formed to silence individuals from speaking about an individual or a company. Breaking these non-disclosure agreements can result in lawsuits and financial penalties. Defamation is an action of damaging the reputation of someone, which can also be slander or libel. Lawsuit is a claim or dispute brought to a court for adjudication. The "prior bad act" law in New York states that evidence of an individual's prior acts is usually not admissible in a New York criminal trial. However, evidence of past crimes, wrongs, or other acts may be admissible under certain limited situations. With the \#MeToo movement coming to light among other movements now forming around the world, these movements are challenging the judicial system and how cases related to sexual abuse and violence are handled, school and campus policies are being challenged to help students feel more comfortable about speaking out against campus wide abuse. However, with 
movements surfacing around the world, in some countries there remains strict hierarchical codes and regulations that make it difficult for survivors/victims of sexual abuse and violence to speak out. They are made to feel ashamed and embarrassed of their abuse and that if they report it, it will only bring more shame to their peers and family members. In some countries, it is frowned upon to accuse men of sexual abuse and violence since they are considered almost superior over women.

In a New York Times Article, Weinstein Is Convicted. Where Does \#MeToo Go From Here? (Kantor 2020). This article states that Michael Bloomberg, a former mayor of New York City, businessman, author, and philanthropist stated that he has agreed on releasing three women's non-disclosure agreements so they could publicly describe complaints against him. A nondisclosure agreement is a confidentiality agreement in which it is intended to silence individuals involved in the contract from revealing any information or knowledge. Since 2017, at least twelve companies have passed laws restricting access to the use of these agreements. New Jersey has made them unenforceable if victims or survivors decide to break the agreement. Google, Microsoft, Uber and Conde Nast have also joined in this effort. California has implemented a new law that restricts confidentiality agreements once a lawsuit or formal complaint has been filed, but many settlements are signed early in the process. Dr. Jeff Goodwin, a New York University Professor said, "Without collective action aimed at legislation on the order of Civil Rights Act, it's hard for me to believe that a purely legal strategy is going to bring about a fundamental change in power." 
Evolving Definition of Movement. This theme refers to the \#MeToo movement specifically. This theme refers to a movement that has provided many survivors and victims' hope of change for women's rights. Tarana Burke, a survivor of sexual abuse formed the \#MeToo movement in 2006, which became viral from a Twitter post from Alyssa Milano in 2017. However, some individuals do not see the movement as a victory, but rather as a weapon to target certain individuals to seek a form of vengeance. The codes that were identified are listed: victimblaming, vindictiveness, victory, women's rights, equality, credibility, racist, internet, allegations, verdict, innocent, guilty, appeal, hypocrisy, vengeance, partisan political weapon, male-guilt, due process, law enforcement, bullying, and toxic masculinity. Throughout the newspaper publications some celebrities around the world denounced the movement as a form of clumping all men into one bucket per say and how some behaviors should not be considered inappropriate. Some even went on to say that individuals are speaking out as a form of vengeance for not receiving a job offer or promotion or as a way to gain some monetary value.

In regard to these codes, victim-blaming is when the victim of a crime is held responsible in whole or in part for crimes that have been committed against them. Vindictiveness is a strong desire to get back at someone, similar to vengeance. Victory is an act of defeating an enemy or opponent or other competition. Women's rights are the rights and entitlements claimed for women and girls worldwide. Equality is the state of being equal in status, rights, and opportunities. Credibility is the quality of being trusted or believed in. Racist is when a person or persons is prejudiced towards a person or people on the basis of racial or ethnic groups. Allegations are a claim or assertion that someone has done something illegal or wrong. Verdict is a decision on a disputed issue in a civil or criminal case. Appeal is when a request is made to a higher court for a reversal of the decision of a lower court. Hypocrisy is the practice to have 
moral standards or beliefs to which one's behavior does not conform. Partisan political weapon was used to describe the \#MeToo movement in which an article described it as form of vengeance seeking and to obtain personal victories such as monetary value. Male-guilt is the process of placing all blame on males to make them feel ashamed. Due process is fair treatment through the normal judicial system. Law enforcement is a department of individuals who enforce laws, investigate crimes, and make arrests. Bullying is a tactic that seeks to harm, intimidate, or coerce someone who is perceived as vulnerable. Toxic masculinity is a set of attitudes and ways of behaving stereotypically associated with or expected of men.

\section{Men Who Were Accused of Sexual Violence (Some have either dismissed or denied the}

allegations, others have been convicted). This theme refers to the men who were accused of sexual abuse and violence. Some of the accused throughout the analysis of these newspaper publications were not convicted but either under investigation or accusations were voiced with no legal repercussion. The individuals who were accused and/or convicted consist of: Donald Trump (President of the United States), Joe Biden (Candidate for the President of the United States), Harvey Weinstein (producer), Bill Cosby (comedian and actor), Woody Allen (director), Mayor of Seoul Park Won-soon, Judge Dyson Heydon, Former New York Attorney General Eric Schneiderman, Judge Stephen R. Reinhardt, Former President of Costa Rica Oscar Aria, Garrison Keillor (comedian), Justice of the Supreme Court Brett Kavanaugh, University of Illinois Professor Jay Kesan, former professional basketball player Kobe Bryant, former UK Member of Parliament Charlie Elphicke, R. Kelly (singer and songwriter), Michael Jackson (singer and songwriter), Alabama State Senate Roy S. Moore, Staff Secretary for Whitehouse Rob Porter, Speechwriter for Whitehouse David Sorensen, and Bollywood actor Alok Nath. The men 
listed above held positions as actors, athletes, producers and directors, singers and songwriters, comedians, and political and government positions. According to Rainn.org, a majority of perpetrators are someone known to the survivor/victim. Approximately eight out of 10 sexual assaults are committed by someone known to the survivor/victim. These men mentioned have either been convicted or have been accused of some type of sexual violence. Some have denied and dismissed the allegations presented before them, some have been convicted and some are still under trial or under investigation, others have been accused but currently face no legal repercussions. For example, the sixty-seven-year-old, Harvey Weinstein was sentenced to twenty-three years in prison for rape and sexual assault. He was found guilty in an extensive New York City trial. His lawyers plan to appeal his conviction; more than ninety women accused Weinstein but only a certain few were able to testify under the statute of limitations. Bill Cosby was found guilty of three counts of sexual assault and was sentenced to serve three to ten years; more than sixty women accused Cosby.

Women Who Came Forth About Their Sexual Abuse. This theme refers to the women who kept their memories of abuse repressed for years in fear of speaking out. Now, many individuals are coming forward in hopes that they will receive justice and that many other survivors/victims will gain the courage to do the same. Some of the survivors/victims include: Andrea Constand (former operations director of a basketball team with Temple University), Tara Reade (former assistant for Joe Biden), Dylan Farrow (Woody Allen's adopted daughter), Tarana Burke (founder of the \#MeToo movement in 2006), Rose McGowan (actress and spokeswoman for the \#MeToo movement), Ashley Judd (actress), Asia Argento (actress and singer), Miriam Haylei (producer), French founder of \#BalanceTonPorc Sandra Muller (journalist), the first high-profile 
actress to speak out in France Adele Haenel, Mhairi Morrison (actress), Drew Dixon (producer for Def Jam Records), Women in the military, and women around the world: China, North/South Korea, France, India, etc. These women who came forth about their sexual victimization served as actresses, athletes, journalists and authors, former assistants and secretaries, singers and songwriters, and more. Most of the survivors/victims who came forth about their sexual victimization were celebrities and officials versus ordinary individuals. It was originally decided that the appropriate terminology to be used throughout the research paper would be "survivors," because using "victims" develops this ideology that individuals are still trapped in their abuse, however after careful analysis of the articles it was identified that some women did not survive their abuse so it was later determined to use both survivors and victims. Tarana Burke started the \#MeToo movement back in 2006 to support survivors of sexual violence and abuse. Then in 2017, Alyssa Milano created the Twitter hashtag \#metoo saying, "women who have been sexually harassed or assaulted write \#metoo." The hashtag went viral instantly, which enforced the movement even more. However, it is more difficult for survivors/victims of sexual abuse and violence to come forward in other countries. Women are often shunned and chastised into believing it is their fault and to keep it a secret and not come forward as it will bring embarrassment to themselves, their peers and family. The women who come forward about their abuse and abusers in other countries are faced with lawsuits such as defamation lawsuits in which the survivors/victims are forced to apologize and pay financial penalties to their abuser. However, with similar movements like the \#MeToo movement being formed all over the world, women are becoming more vocal about their rights and demanding justice. 
Survivors, Accused, and Perpetrators Have Different Characteristics and Traits. This category describes the impact of the \#MeToo movement and types of sexual violence in reference to codes such as: race, gender, class, and ethnicity. The survivors, victims, accused and perpetrators all have different characteristics and traits. Race refers to a group of people who have common visible traits such as skin color, facial features, etc. Gender could be male or female, however non-binary could also be considered and was implemented in this research paper. Class is a system of ordering a society in which individuals are divided based on economic or perceived status.

An example of characteristics and traits would be in a New York Times article, A Documentary for the \#MeToo Era (Tillet 2020), a documentary was created called On The Record, which addresses longstanding criticism that black women have been overlooked in the conversation about sexual assault and power. Drew Dixon speaks of her allegations against Russell Simmons along with other African American women such as Tina Baker, Toni Sallie, Christina Moore, Sherri Hines, Alexia Norton, Sil Lai Abrams, and Jenny Lumet. Simmons has denied all accusations of nonconsensual sex. Dixon, a former A\&R executive at Simmons's Def Jam Records left the music industry because of her experience and separated from her husband as a result of the heavy toll it took on her. This documentary is one of the \#MeToo era following others like Untouchable about Harvey Weinstein, Leaving Neverland about Michael Jackson, Surviving R. Kelly, and Jeffrey Epstein: Filthy Rich. These documentaries exemplify how celebrity and wealth not only provided powerful men with countless opportunities for sexual abuse but entitled them to a set of protections that prevented them from getting caught. 
The Types of Stories Have Been Voiced and Portrayed Differently. This theme refers to the types of story being portrayed. Throughout the sample size of the one-hundred and fifty newspaper publications, there have been different classifications, types, and tones throughout. The types of news classification/types of codes consist of: Regular News, Opinion, Politics, Business, Entertainment/Arts, Lifestyle/Leisure, Science and Technology and Medicine. The types of treatment consist of: News, Feature, Commentary/Criticism, and Other. Lastly, the types of tone consist of: Negative/Critical, Positive/Non-Critical, and Neutral. Many authors publish articles and portray the news differently. There are also many types of readership, but the researcher identified three: General News-Readers, Specific Readership Other Survivors, and Specific Readership Movement Supporters. It is important to note that throughout this research paper a news publication can be more than one code throughout each category.

\section{"Whisper Networks" Have Been Created to Warn Others About Predatory Abusive}

Individuals. This theme refers to whisper networks and silence breakers that were formed as a sort of private passageway between women to warn of predatory and abusive men. These networks and passageways exist because women are fearful of speaking out about their abuse in fear that they will receive backlash and scrutiny. As a result, these types of codes were formed: power, money, and politics. Women are fearful of speaking out about their abuse because it usually involves someone who is powerful, wealthy, or an individual who is well-known such as a celebrity or official. When coming forth about abuse, individuals can face constant scrutiny and a series of questions to determine whether their story seems credible or not. Their personal information is spread throughout the media, objectifying them to relive their traumatic experience over and over again. These survivors/victims who speak out against their abuse are 
put under the spotlight. Individuals who come forward face the risk of being publicly humiliated by their abuser and other counterparts. However, some of the survivors/victims who were in these whisper networks and who were considered silence breakers have publicly come forward about their abuse in hopes that other survivors/victims do the same.

In a NewsBank article, The forbidden fruit, aka Donald Trump (Stephens 2020), it states that "whisper networks" consisted of women quietly warning other women about predatory and abusive men in their work and social environments. Women were afraid publicly to second-guess aspects of a movement they felt had lost a sense of fairness and proportion, largely out of fear of social media's call-out culture.

Acts to Recognize Inappropriate Behaviors. This theme refers to legal intervention and potential solutions that have been presented throughout the newspaper publication sample size. These codes consist of restorative justice, workplace harassment training, eliminate nondisclosure agreements (NDA's), extend or repeal statute of limitations. The overarching theme here is that everyone needs to recognize and be aware of their behaviors and in the midst of the \#MeToo movement and other movements forming around the world it appears that there will be some changes enforced in the future. Many survivors/victims courageously spoke out against their abuse despite not being able to testify in court due to the statute of limitations. Other survivors/victims remain under non-disclosure agreements and are not yet able to speak out against their abuser. In one newspaper article a company called Rserving implemented a workplace harassment training program that made it mandatory for employees to take. Another newspaper publication asked readers to provide solutions on inappropriate behaviors and what 
individuals should do to repair the damages they have caused. It was recommended that restorative justice programs and therapy programs be implemented to repair the damages done to not only the survivors/victims, but other individuals involved as well instead of incarceration or severe punishment.

In a New York Times article, What To Do With the 'Bad Men' of the \#MeToo movement (Baker 2018), an investigative reporter explored questions of what to do with the men who have been taken down by the \#MeToo movement and allowed her readers to respond to the questions. One reader and correspondent suggested that men should volunteer their time helping abuse victims such as cleaning at a homeless shelter or visiting nursing homes, another said men should attend classes like an Alcoholics Anonymous where they would have to pay for therapy sessions and other services provided, and another mentioned a restorative justice program to reintegrate the men back into society. Restorative justice is a system of criminal justice that focuses on a form of rehabilitation of offenders through reconciliation with the survivors/victims involved and the community. In a NewsBank article, Rserving helps employees, employers avoid harassment (Clement 2020), states that the staff at Rserving, a Madison-based online training provider says that all 50 states have approved the company's workplace harassment training course. Jessi Daw, an Rserving course designer, said, "With the \#MeToo and \#TimesUp movements, awareness around workplace harassment has increased dramatically, and victims are more likely to take action." Workplace harassment training is becoming more popular among companies and businesses as they want to eliminate situations from arising in the future by making their employees aware of behaviors that constitute as inappropriate. It is a form of mandatory 
compliance training. The training can be set up as modules on a computer screen in which an employer goes through a series of readings and tests.

In a NewsBank article, Statutes of-limitation-have value (Powell 2020), it states that repealing or extending statutes of limitations ratifies and denies that crime victims have a duty to come forward promptly. The longer the accusations are delayed, the harder they are to prove, as evidence deteriorates, and the motives of accusers are more easily challenged. The author goes on to say that there is not victory for victims of sexual assault and that this only mocks them (referring to Weinstein case). Like previously mentioned, statute of limitations is a law that sets the maximum time individuals have to initiate legal proceedings from the date of the alleged offense. However, cases such as murder typically have no maximum period under statute of limitations. 


\section{DISCUSSION}

This research took on a mixed methods approach to discuss both qualitative and quantitative research questions. The quantitative research questions looked at what determines the critical portrayal of the \#MeToo movement in the news media, specifically newspaper articles.

Quantitative findings summarized. For the quantitative findings, the first hypothesis predicted that female authors were more likely to provide a critical tone for the \#MeToo movement than male authors. Throughout the research it did appear that female authors were providing a more critical tone in how cases were being resolved. It appeared as though the tone was aimed more with changing the law and policies. However, there were some female authors who denounced the movement completely. My first hypothesis was proven significant. Based on the quantitative findings, female authors did have a more critical tone in regard to the \#MeToo movement versus their male counterparts.

The second hypothesis predicted that the national media in the United States was going to provide a more critical analysis on the \#MeToo movement in America more than International news. From reading the newspaper publications, The New York Times and America's NewsBank did provide a more critical analysis of the movement versus the other newspaper platform, $B B C$. $\mathrm{BBC}$ news provided insight on upcoming books and documentaries coming out in regard to victimization while the other platforms provided insight on their views about the cases and laws surrounding it. My second hypothesis was proven significant, as the national media had a more critical analysis than international media. However, as I emphasized in the finding section it is important to remember that there were more national news articles that international news articles that can impact the cross-tabulation results 
For the quantitative findings, the third hypothesis predicted that the critical tone of coverage of the \#MeToo movement in the media will vary by region of publication in the United States. When analyzing the newspaper publication in the United States, it did appear that most of the publications were from the Northeast, especially New York. Not surprising since the Weinstein trials occurred in New York. Before analyzing the newspaper publications, it was originally thought that there were be more diversity with the newspaper publications in the United States. My third hypothesis was significant (although more news articles were from Northeast) because -- it was observed that articles from the Northeast exceeded their counterparts with a critical tone.

The fourth hypothesis predicted that the coverage of the \#MeToo movement was more prominent in the years of origination (2006-2017) than recent times. Before gathering the newspaper, publications there was a concern that there would be no significant news on the movement in recent years and that the news publications were more focused on other recent happenings in today's time. The movement was originated in 2006 by Tarana Burke but was adopted by Alyssa Milano when she used the hashtag "\#MeToo" in a Twitter post. However, with the Weinstein, Cosby and other cases now coming forth, the movement was reintroduced. It was discovered that there were actually more recent publications of the movement than publications in the sample set in 2017 and 2018. While the findings were not significant, the percentages were opposite to what the researcher had predicted - the percentages suggest that in fact, more recent articles took a critical tone in reporting the \#MeToo movement than the articles years before.

The fifth hypothesis predicted that celebrity incidents of the \#MeToo movement will receive more media attention than non-celebrity incidents - this was validated. While reading 
and analyzing each newspaper publication it did appear that there were more publications about celebrities and officials than ordinary people.

The sixth hypothesis predicted that the news publications which discusses physical victimization are more likely to take a critical tone in reporting than those that discuss nonphysical victimization. The results were proven not significant.

The final hypotheses looked into whether the legal status of a case has been under trial or otherwise has an impact on the tone of reporting. The non-significant crosstabulation's results suggest that while there was a difference between the groups but they were also opposite to what was predicted- in fact cases which have reached a verdict seemed to be more critically reported

In conclusion, the overall hypotheses one through three were more significant and the rest or either not significant or different from the direction originally predicted. Following the research quantitative question asked at the beginning of the research paper, it was discovered that there was a more critical/negative tone reported among female authors and in the National region, specifically the Northeast region than the other counterparts tested. There was also a more critical/negative tone when mentioning celebrities and officials with combined types of overall victimization and combined legal statuses of cases.

Research Question Quantitative: What determines the portrayal of the \#MeToo movement in the media in newspaper articles?

Based on the limited test of hypothesis run for cross tabulations here in the analysis it seems like gender of the author, source of publication (national versus international), region of publication nationally as well as celebrity status mentioned in the news article seems to determine whether a critical tone will be taken in assessing cases about \#metoo. 
Qualitative findings summarized. From analyzing the sample set of one-hundred and fifty newspaper articles, the time of publication seemed to be less than one year, which is surprising since the \#MeToo movement originated in 2006 and 2017. There were no male survivors/victims reported and no female perpetrators recorded as well. There were also no minors as perpetrators, but only a small few of minors as victims. The type of overall victimization and the type of sexual victimization seemed to range from not just one category but more than one category for most articles. The legal status of case seemed to range as well. There was not one specific case status assigned to a particular article, but it was a range of legal status among many articles analyzed. Combining categories was important to make the data concise and accurate as possible. Surprisingly, there seemed to be more opinion and commentary/criticism pieces and negative/critical than there were positive/non-critical or neutral. One would think that newspaper articles would report regular news versus opinion or commentary/criticism pieces.

Research Question Qualitative: How is the \#MeToo movement portrayed in the media in newspaper articles?

When looking at the themes created it summarizes that the \#MeToo movement has become a global phenomenon, with other movements forming around the world such as \#BelieveAllWomen, \#BalanceTonPorc (Expose Your Pig), \#UnDiasInNosotras (A Day Without Us), \#Woyeshi (Me Too), \#TimesUp, and \#NiUnaMenos (Not One Less). The human impact of these movements can cause the survivors/victims to experience mental/emotional, physical health concerns. These health concerns can consist of: anger, fear, post-traumatic stress disorder, humiliation, substance-abuse, suicidal ideation, panic attacks, and more. Sexual behaviors can vary, however, from examining the newspaper articles in the sample set it appears that only young girls and women came forward about their alleged abuse versus young boys and men. 
However, that does not mean that women are the only ones who experience sexual abuse and violence. Some of the accusations and allegations are still under investigation, these individuals who spoke out against their abuse and abuser were able to convict high-profile and elite celebrities and have inspired other survivors/victims to speak out as well. These survivors/victims who were too scared to speak out against their abuser in fear of humiliation and retaliation formed networks such as "whisper networks" to warn others of predatory and abusive men. These individuals were later called the "silence breakers" because of their decision to come forth about their abuse that they repressed for many years. These movements being formed around the world are challenging the judicial system to acknowledge women's right and to take action to provide the proper justice. These movements do not aim to target specific individuals, but to promote equality and eliminate continued violence that is often neglected. Each story in the sample set was portrayed differently, but many provided personal opinion and commentary/criticism especially a negative/critical tone toward the \#MeToo movement and individuals involved. The \#MeToo movement is a controversial topic and some depicted the movement as lumping all men into one bucket and how the movement targets specific individuals and others said the movement was a victory and that it challenges laws and policies to change for the better; to promote equality for all and to provide due process. The overarching theme is that these movements being created want to challenge the judicial system and change the laws and policies surrounding sexual abuse and violence, but others argue that there are other ways to enforce justice without the use of actual punishment. Others suggest that there are restorative justice programs and workplace compliance harassment training to avoid these types of incidences from occurring in the future. 
When looking at the themes created it portrays that movements are being created around the world to combat violence and to seek proper justice. Movements such as:

\#BelieveAllWomen, \#BalanceTonPorc (Expose Your Pig), \#UnDiasInNosotras (A Day Without Us), \#Woyeshi (Me Too), \#TimesUp, and \#NiUnaMenos (Not One Less) protest equality and women's rights and to put an end to violence. Though, many survivors/victims have spoken out against their abuser, there are still some that remain in silence, too afraid to speak out and form "whisper networks" to warn others about predatory and abusive individuals. The human impact of these movements have inspired many to speak out but have left painful memories and concerns. These survivors/victims may experience mental/emotional, physical, vicarious and financial concerns. These concerns can consist of: anger, fear, post-traumatic stress disorder, humiliation, substance-abuse, suicidal ideation, panic attacks, and more. Sexual behaviors can vary and even though from the sample set it was discovered that only young girls and women came forth about their abuse, that does not mean that young boys and men are not abused as well. Each story in the sample set of one-hundred and fifty articles was portrayed differently, but a great majority of the articles provided personal opinion and commentary/criticism with a negative/critical tone. This is definitely a controversial topic and there is a divide on whether these movements being formed are impactful or not. These movements want to challenge the judicial system in hopes that laws and policies will change surrounding sexual violence and abuse and provide the proper justice. These movements desire equality and to promote and acknowledge women's rights across all spectrums. 
Theoretical Considerations. There were two theories mentioned throughout this research paper: feminist theory and mass media theory. Feminist activists have lobbied for women's legal rights (rights of contract, property rights, voting rights); for women's right to bodily integrity free from interference and autonomy, for abortion rights, and for reproductive rights (including access to contraception and quality prenatal care); for protection of women and girls from domestic violence, sexual harassments and rape, for workplace rights (maternity leave, and equal pay); against misogyny; and against other gender-specific discrimination against women (History and Theory of Feminism 2020). It was decided that liberal feminism would be more applicable to the \#MeToo movement because this type of feminism desires equality in the sense of sameness of attainment and treatment. The feminist theory and the feminism movement are working towards treating males and females equally. This \#MeToo movement aims to not target specific individuals, but to provide justice for the survivors/victims who repressed their abuse for years and have finally come forth to speak publicly. The movement challenges the judicial system to strategically analyze cases involving sexual abuse and violence and provide the proper justice. The movement's motive is to put an end to abuse and excuses and to take some serious action so that this abuse stops indefinitely. The movement challenges the judicial system to make systematic changes in order to bring proper justice. However, not everyone believes the movement is doing a justice. Some self-proclaimed feminists believe that many allegations and incidents of sexual harassment were too minor to warrant criticism. They argue that the movements is losing its sense of purpose and meaning because there is such a wide spectrum of sexual behavior.

By saying "me too," an individual makes themselves a part of a broader group and chooses to stand with others who have been harassed, assaulted, or raped. This solidarity is 
powerful. It is still rare to see such a large group of women identifying their suffering as women's suffering, claiming that they have all been harmed by the same forces of sexism, and together demanding that those forces be defeated (Donegan 2018). In this light, the diversity and breadth of the \#MeToo Movement is not a weakness, but a strength. If so many women, with so many different kinds of lives, have experienced the same sexist behavior from men, then it becomes easier to believe that the problem goes beyond individuals and instead relates to wider cultural forces.

The mass media theory explains how media is portrayed to the audience and how the audience interprets the media's messages. The \#MeToo movement became a viral sensation and there has been an influx of media reports of the survivors and victims' stories. Many celebrities, television moguls, political figures and more well-renown individuals have been accused of sexual abuse and the media reports each story differently, which leaves it up to the audience to decipher their own beliefs and opinions about the situation. The media outlets try not to express bias throughout their stories, but it can sometimes be difficult not to express opinions on the matter. However, while analyzing the newspaper articles there were more opinion and commentary/criticism pieces than there were actual news about the movements mission and opinions about the survivors/victims credibility of their abuse. Under the mass media theory is the agenda setting theory, which assumes that with the passage of time, media agenda becomes the public agenda and that they are intertwined with each other. The influence of the media can affect the presentation of the reports and issues made in the news that affects the public's viewpoint (McCombs and Shaw 2011). News reports can form a story in a way that when it is presented it is shown to have more importance and attention than other news that the audience will perceive the story as the most important given to them. 
Practical Implications. There are mixed messages in the media surrounding the \#MeToo movement. There are arguments that the movement is lumping all men into one bucket as perpetrators and there is another argument that the movement is helping change laws and policies to seek due process. The media portrays that cases such as the Weinstein and Cosby case and many other cases are what ignited the \#MeToo movement, but it is not the perpetrators who ignited the movement, it is the survivors and victims who decided to come forth about their abuse because without their voices these perpetrators would be walking free. Without the survivors and victims' constant testimonies and encouraging others to speak up, there would be no justice served and these perpetrators would still be abusing others under the guise of their power and status. It can be very easy to sway an audience when it comes to reporting.

Since the Me Too movement was created by Tarana Burke in 2006, it was a movement that individuals may have overlooked and considered that it was not as newsworthy as some other pressing matters during those times. However, it wasn't until Alyssa Milano made the movement into a hashtag \#MeToo movement and tweeted "Women who have been sexually harassed or assaulted, write \#MeToo," that it became viral. Maybe it was because a celebrity made the post that the movement started to gain some attention, but when Alyssa Milano posted that on her Twitter that's when survivors/victims started to speak up. The movement quickly gained traction as multiple women came forth about their abuse under the high-profile celebrity guise of Harvey Weinstein and Bill Cosby and many other celebrity and official cases. These trials were a nationwide phenomenon, which sparked other movements around the world. The perpetrators did not ignite the movement, but gained momentum from the many individuals who decided to come forth and speak against their abuser even though they had been silenced for many years in fear they would be retaliated against. 


\section{LIMITATIONS}

The final sample size was one-hundred and fifty newspaper publications. It was rather difficult to extract the newspaper publications as $B B C$ does not have an option to categorize newspaper publications chronologically. There are no options available for $B B C$, so the researcher had to chronologically order one-hundred and fifty newspaper publications by hand.

\section{RECOMMENDATIONS}

For future research, it might be beneficial to run a logistic regression. It might also be beneficial to measure the race of the perpetrators and survivors/victims. Originally the researcher was going to include the political ideology of the newspaper publications and also whether the newspaper publications were based off of donor or non-donor, but with time restraints the researcher did not have time to test those variables. It was also rather difficult to research and find evidence to suggest these variables would have any significant impact. Another recommendation for future research would be to examine why young girls and women speak out more against sexual abuse and violence versus young boys and men. 


\section{REFERENCES}

Aalberg Toril, Stylianos Papathanassopoulos, Stuart Soroka, James Curran, Kaori Hayashi, Shanto Iyengar, Paul K. Jones, Gianpietro Mazzoleni, Hernando Rojas, David Rowe \& Rodney Tiffen. 2013. International TV News, Foreign Affairs Interest And Public Knowledge, Journalism Studies, 14:3, 387-406, DOI: 10.1080/1461670X.2013.765636 https://www.tandfonline.com/doi/abs/10.1080/1461670X.2013.76563

Ake, J. 2017. A Brief History of Anti-Violence-Against Women Movements in the United States.

Baker, Katie J.M. 2018. "What to Do With the 'Bad Men' of the \#MeToo Movement." The New York Times, The New York Times, www.nytimes.com/2018/05/02/opinion/bad-menmetoo-movement.html.

Barakso, Maryann and Brian F. Schaffner. 2006. "Winning Coverage.” Harvard International Journal of Press/Politics 11(4):22-44. https://doiorg.ric.idm.oclc.org/10.1177/1081180X06293069

BBC News. 2020. Harvey Weinstein timeline: How the scandal unfolded.

Board, The Editorial. 2020. “The Lessons of \#MeToo's Monster.” The New York Times, The New York Times, www.nytimes.com/2020/02/24/opinion/harvey-weinstein-verdictmetoo.html.

Boyd-Barrett, O. 2000. National and International News Agencies: Issues of Crisis and Realignment. Gazette (Leiden, Netherlands), 62(1), 5-18. https://doi.org/10.1177/0016549200062001001.

Breeden, Aurelien. 2019. "French \#MeToo Movement's Founder Loses Defamation Case." The New York Times, The New York Times, www.nytimes.com/2019/09/25/world/europe/france-sandra-muller-verdict.html.

Carlsen, Audrey et al. 2018. “\#MeToo Brought Down 201 Powerful Men. Nearly Half of Their Replacements Are Women.” The New York Times. Retrieved April 18, 2020 (https://www.nytimes.com/interactive/2018/10/23/us/metoo-replacements.html). (Carlsen et al., 2018)

Carter, C., Branston, G., \& Allan, S. 2002. News, Gender and Power: Vol. Taylor \& Francis e-Library ed. Routledge.

Clair, Robin Patric, Nadia E. Brown, Debbie S. Dougherty, Hannah K. Delemeester, Patricia Geist-Martin, William I. Gorden, Tyler Sorg, and Paaige K. Turner. 2019. “\#MeToo, Sexual Harassment: An Article, a Forum, and a Dream for the Future.” Journal of Applied Communication Research 47, no. 2. 111-29. doi:10.1080/00909882.2019.1567142. 
Clement, Chuck. 2020. "Rserving helps employees, employers avoid harassment," Madison Daily Leader, The (SD), pp.2.

Crawley, K., \& Simic, O. 2019. Telling stories of rape, revenge and redemption in the age of the TED talk. Crime, Media, Culture, 15(2), 259-278. https://doi-org.ric.idm.oclc.org/10.1177/1741659018771117.

Donegan, M. 2018. How \#MeToo revealed the central rift within feminism today. Retrieved from https://www.theguardian.com/news/2018/may/11/how-metoo-revealed-thecentral-rift-within-feminism-social-individualist

Dubied, A., \& Hanitzsch, T. 2014. Studying celebrity news. Journalism, 15(2), 137143. https://doi.org/10.1177/1464884913488717

Elsesser, Kim. 2019. "The Latest Consequence Of \#MeToo: Not Hiring Women." Retrieved (https://www.forbes.com/sites/kimelsesser/2019/09/05/the-latest-consequence-ofmetoo-not-hiring-women/\#306d3ba0280b).

Evans, J. 1995. Feminist theory today: An introduction to second-wave feminism. Retrieved from https://ebookcentral.proquest.com

Flores, N. M. 2020. Harassment at conferences: will \#MeToo momentum translate to real change? Gender \& Education, 32(1), 137-144. https://doiorg.ric.idm.oclc.org/10.1080/09540253.2019.1633462

Gannon, Theresa A., and Emma K.A. Alleyne. 2012. Female Sexual Abusers' Cognition: A Systematic Review. Trauma, Violence, \& Abuse. SAGE Journals. 14(1), 67-79.

https://doi.org/10.1177/1524838012462245

Gender.cawater-info.net. 2020. History And Theory Of Feminism. [online] Available at: $<$ http://www.gender.cawater-info.net/knowledge_base/rubricator/feminism_e.htm $>$ [Accessed 16 November 2020].

Gibson, C., Davenport, S., Fowler, T., Harris, C. B., Prudhomme, M., Whiting, S., \& Simmons-Horton, S. 2019. Understanding the 2017 "Me Too" Movement's Timing. Humanity \& Society, 43(2), 217-224. https://doi-org.ric.idm.oclc.org/10.1177/0160597619832047

Greene, V. S., \& Day, A. 2020. Asking for It: Rape Myths, Satire, and Feminist Lacunae. Signs: Journal of Women in Culture \& Society, 45(2), 449-472. https://doiorg.ric.idm.oclc.org/10.1086/705005. 
Gronert, N. M. 2019. Law, campus policy, social movements, and sexual violence: Where do we stand in the \#MeToo movement? Sociology Compass, 13(6), N.PAG. https://doiorg.ric.idm.oclc.org/10.1111/soc4.12694.

Gunderson, M. P. 2019. Gender and the Language of Judicial Opinion Writing. Georgetown Journal of Gender \& the Law, 21(1), 1-34.

Heyboer, Kelly. 2020. "College rape reports rise 15\% in the wake of \#MeToo era Reports," Star-Ledger, The (Newark, NJ), February 21, pp.011.

History.com Staff. 2018. How Sexual Assault Has Been Portrayed-or Erased-Throughout History. (History.com Staff, 2018)

History and Theory of Feminism. (http://www.gender.cawaterinfo.net/knowledge base/rubricator/feminism_e.htm).

Honderich, Holly. 2020. “Joe Biden Assault Claim: What Does 'Believe Women' Mean Now?” BBC News, BBC, www.bbc.com/news/world-us-canada-52592979.

Jaffe, S. 2018. The Collective Power of \#MeToo. Dissent (00123846), 65(2), 80-87. https://doi-org.ric.idm.oclc.org/10.1353/dss.2018.003. (Jaffe, 2018).

Kantor, Jodi. 2020. "Weinstein Is Convicted. Where Does \#MeToo Go From Here?" The New York Times, The New York Times, www.nytimes.com/2020/02/26/us/harvey-weinsteinmetoo-movement-future.html.

Keyton, Joann, Robin Clair, Cristin A. Compton, Debbie S. Dougherty, Diane Forbes Berthoud, Jimmie Manning, and Jennifer A. Scarduzio. 2018. "Addressing Sexual Harassment in a Sexually Charged National Culture: A Journal of Applied Communication Research Forum." Journal of Applied Communication Research 46 (6): 665-83. doi:10.1080/00909882.2018.1546472.

Khan, M. 2010. Encyclopaedia of mass media: Volumes 1- 3. Retrieved from https://ebookcentral.proquest.com

Kristin K. Schaaf, Thomas R. McCanne. 1998. Relationship of Childhood Sexual, Physical, and Combined Sexual and Physical Abuse to Adult Victimization ad Postraumatic Stress Disorder. Child Abuse \& Neglect. Volume 22, Issue 11. Pages 1119-1133. ISSN 01452134. https://doi.org/10.1016/S0145-2134(98)00090-8.

Larabee, Ann. 2018. 'Editorial: Celebrity, Politics, and the 'Me, Too' Moment.” Journal of Popular Culture 51 (1): 7-9. doi:10.1111/jpcu.12650.

Leung, Rebecca, and Robert Williams. 2019. “\#MeToo and Intersectionality: An Examination of the \#MeToo Movement Through the R. Kelly Scandal." Journal of Communication Inquiry 43, no. 4: 349-71. doi:10.1177/0196859919874138. 
MacKinnon, Catharine A. 2019. "Where \#MeToo Came From, and Where It's Going." The Atlantic. Retrieved April 18, 2020

(https://www.theatlantic.com/ideas/archive/2019/03/catharine-mackinnon-what-metoo-haschanged/585313/). (MacKinnon, 2019)

Mahdawi, Arwa. 2019. "Men Now Avoid Women at Work - Another Sign We're Being Punished for \#MeToo." Retrieved (https://www.theguardian.com/lifeandstyle/2019/aug/29/menwomen-workplace-study-harassment-harvard-metoo).

Manning, Jane. 2020. "Fix this N.Y. sex crimes statute," New York Daily News (NY), February 26, pp. 22CS.

McCombs, M. and Shaw, D., 2011. Agenda Setting Theory. [online] Communication Theory. Available at: <https://www.communicationtheory.org/agenda-setting-theory/> [Accessed 14 May 2020].

Naveed, Fakhar. 2019. "Different Theories Used in Mass Communication." Mass Communication Talk. (https://www.masscommunicationtalk.com/different-theories-used-masscommunication.html).

Powell, Chris. 2020. "Statutes of limitation have value," Republican-American (Waterbury, CT), March 22, pp. F1.

RAINN.org 2020. “Types of Sexual Violence.” Rape, Abuse \& Incest National Network.

Ryzik, Melena et al. 2018. "How Saying \#MeToo Changed Their Lives." The New York Times. Retrieved April 18, 2020 (https://www.nytimes.com/interactive/2018/06/28/arts/metoomovement-stories.html). (Ryzik et al., 2018)

Sigmon PhD, Sandra T., Melodie P. Greene PhD, Kelly J. Rohan BA, and Jennifer E. Nichols BA. 1997. "Coping and Adjustment in Male and Female Survivors of Childhood Sexual Abuse.” Journal of Child Sexual Abuse, 5:3, 57-75, DOI: 10.1300/J070v05n03 04

Stephens, Bret. 2020. “The forbidden fruit, aka Donald Trump," Northwest Arkansas Democrat-Gazette (AR), February 21, pp. 15.

Taylor, James. 2019. “Me Too Movement.” Me Too Movement, pp.1-7.

Thrall, Trevor A., Jamie Lollio-Fakhreddine Jon Berent, Lana Donnelly, West Herrin, Zachary Paquette, Rebecca Wenglinski, and Amy Wyatt. 2008. Star Power: Celebrity Advocacy and the Evolution of the Public Sphere. The International Journal of Press/Politics, 13(4), 362385. https://doi.org/10.1177/1940161208319098

Tillet, Salamishah. 2020. "A Documentary for the \#MeToo Era." The New York Times, The New York Times, www.nytimes.com/2020/06/03/movies/metoo-documentary-russellsimmons.html. 
Tong, R. 2001. International Encyclopedia of the Social \& Behavioral Science. Feminist Theory, 5484-5491. doi: https://doi.org/10.1016/B0-08-043076-7/03945-0

Twohey, Megan, et al. 2020. “All Bets Are Off as Harvey Weinstein's Sexual Assault Trial Opens Today." The New York Times, The New York Times, www.nytimes.com/2020/01/05/us/harvey-weinstein-trial.html.

Villegas, Paulina, et al. 2020. "In Mexico, Women Go on Strike Nationwide to Protest Violence." The New York Times, The New York Times, www.nytimes.com/2020/03/09/world/americas/mexico-women-strike-protest.html.

"Was It 'Sexual Assault' or Just a Bad Date?" 2018. BBC News, BBC, www.bbc.com/news/av/uk-42754808.

Wee, Sui-lee, and Li Yuan. 2019. “They Said \#MeToo. Now They Are Being Sued.” The New York Times, The New York Times, www.nytimes.com/2019/12/26/business/china-sexualharassment-metoo.html.

West Jevin D., Jennifer Jacquet, Molly M. King, Shelley J. Correll, Carl T. Bergstrom. 2013. "The Role of Gender in Scholarly Authorship." PLOS ONE 8(7): e66212.https://doi.org/10.1371/journal.pone.0066212

Williams, Joan C. and Suzanne Lebsock. 2019. "Now What?" Harvard Business Review. Retrieved April 18, 2020 (https://hbr.org/cover-story/2018/01/now-what). (Williams and Lebsock, 2019) 


\section{APPENDIX A: RESEARCH RANDOMIZER FOR ARTICLES BBC, THE NEW YORK TIMES, AND AMERICA'S NEWSBANK}
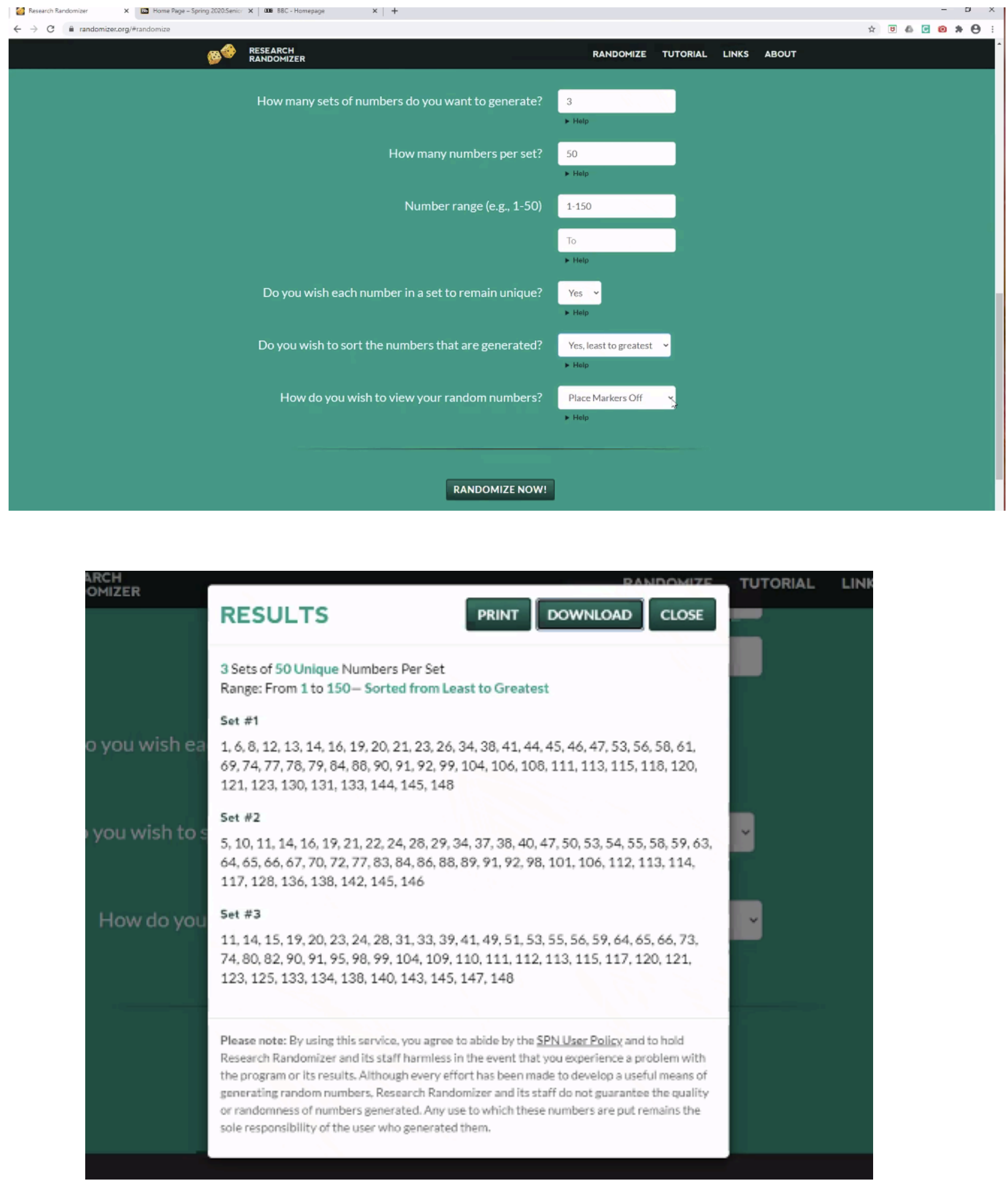


\section{APPENDIX B. CHARTS SUMMARIZING INDEPENDENT AND DEPENDENT VARIABLES}

FIGURE ONE. PIE CHART SHOWING PERCENTAGES OF SOURCE OF NATIONAL AND INTERNATIONAL NEWS MEDIA

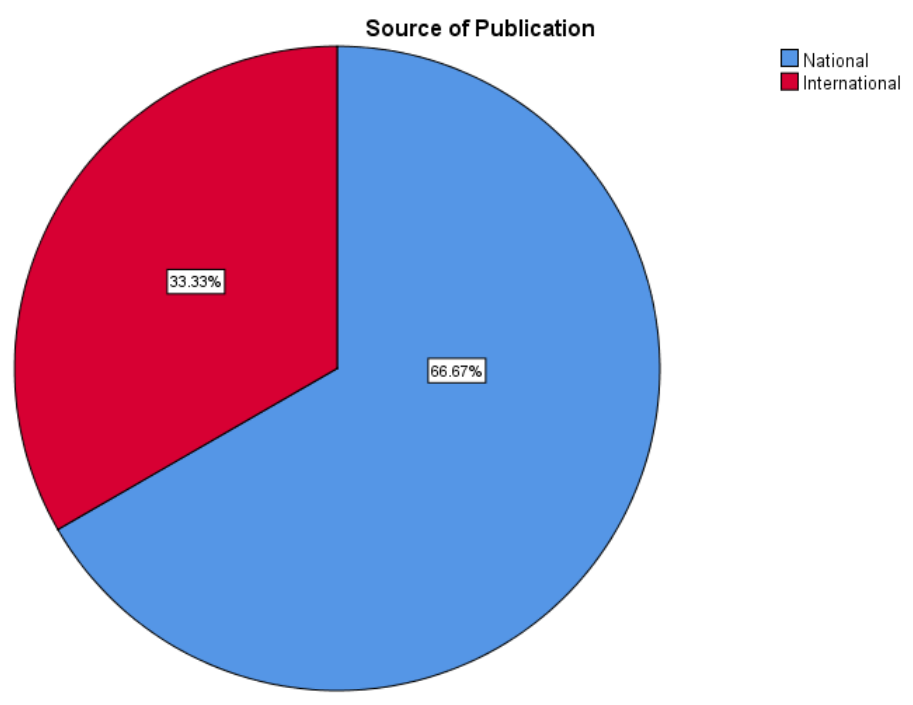

FIGURE TWO. PIE CHART SHOWING PERCENTAGES OF SOURCE OF NATIONAL NEWS MEDIA BY REGION

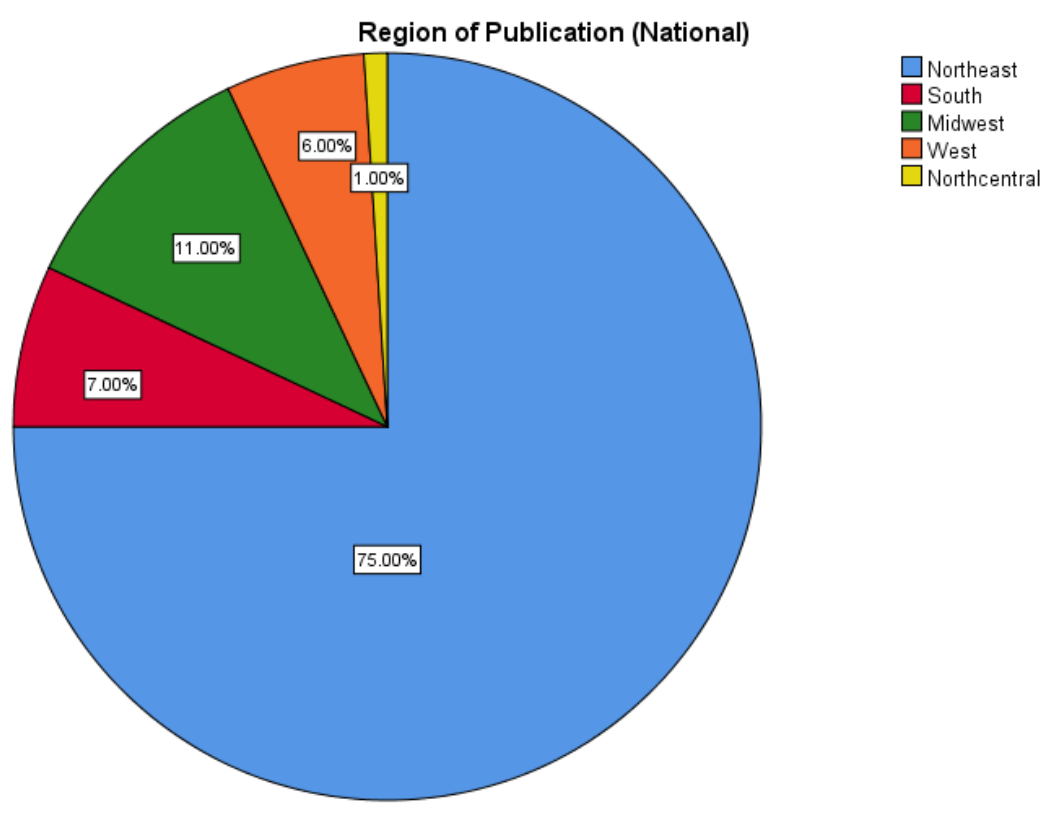


FIGURE THREE. PIE CHART SHOWING PERCENTAGES OF SOURCE OF INTERNATIONAL NEWS MEDIA BY REGION

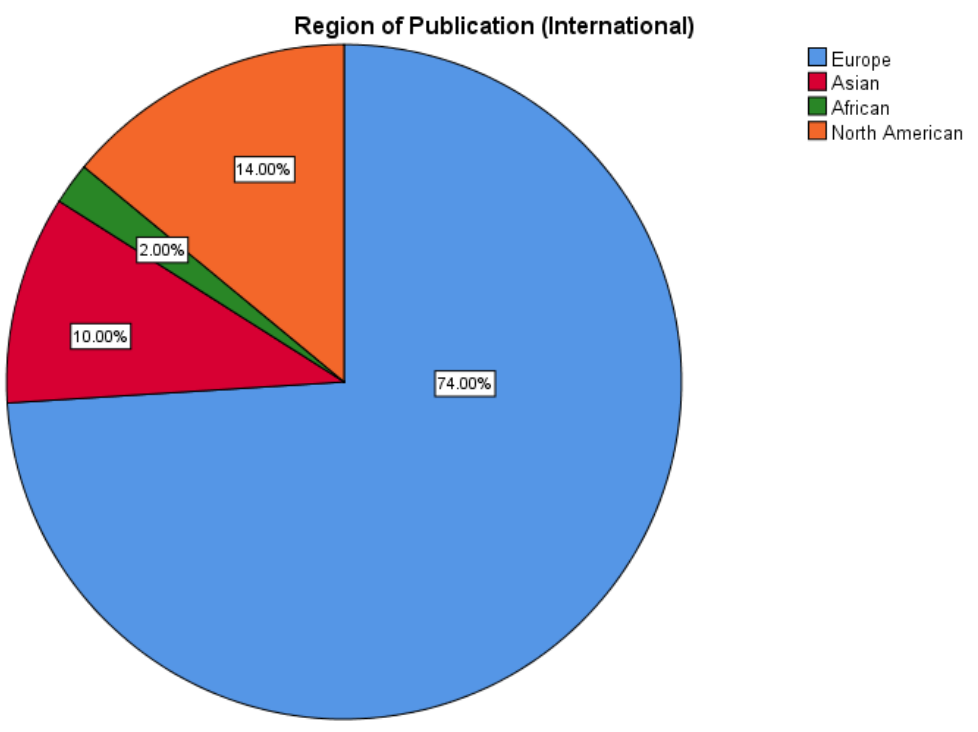

FIGURE FOUR. PIE CHART SHOWING PERCENTAGES OF INTENDED AUDIENCE OF PUBLICATION BY REGION IN NEWS MEDIA

Pie Chart Count of Intended Audience of Publication by Region

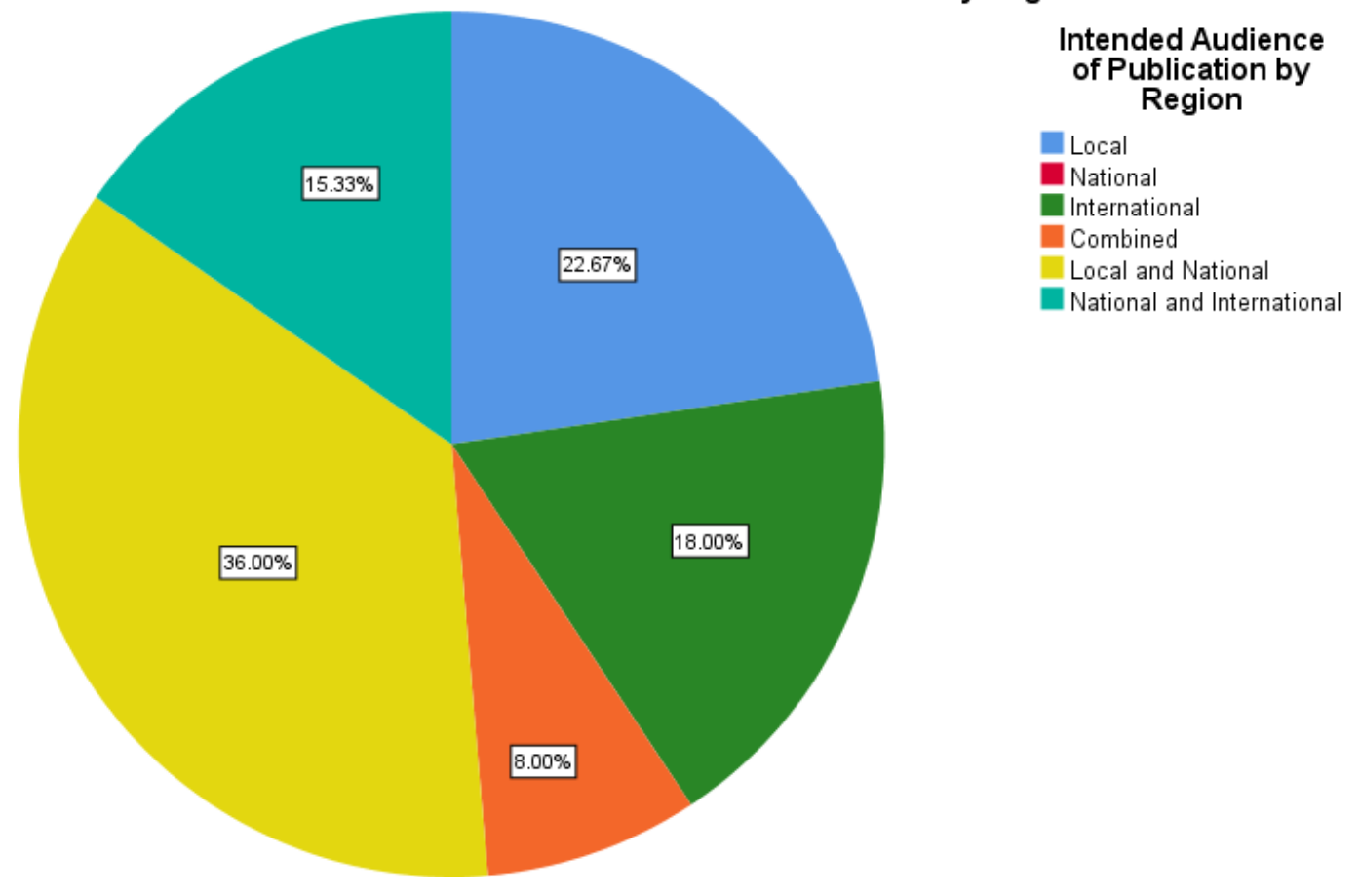


FIGURE FIVE. PIE CHART SHOWING PERCENTAGES OF INTENDED AUDIENCE TYPES OF READERSHIP IN NEWS MEDIA

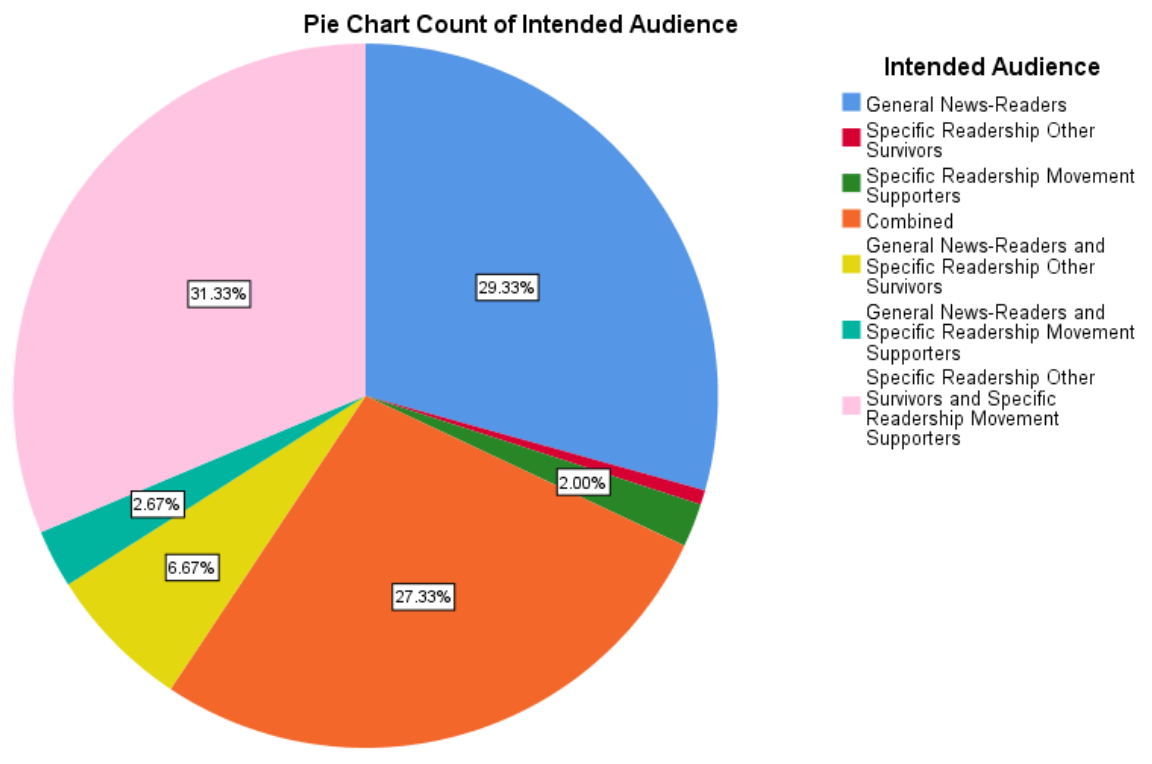

FIGURE SIX. PIE CHART SHOWING PERCENTAGES OF TIME OF PUBLICATION IN NEWS MEDIA

Pie Chart Count of Time of Publication

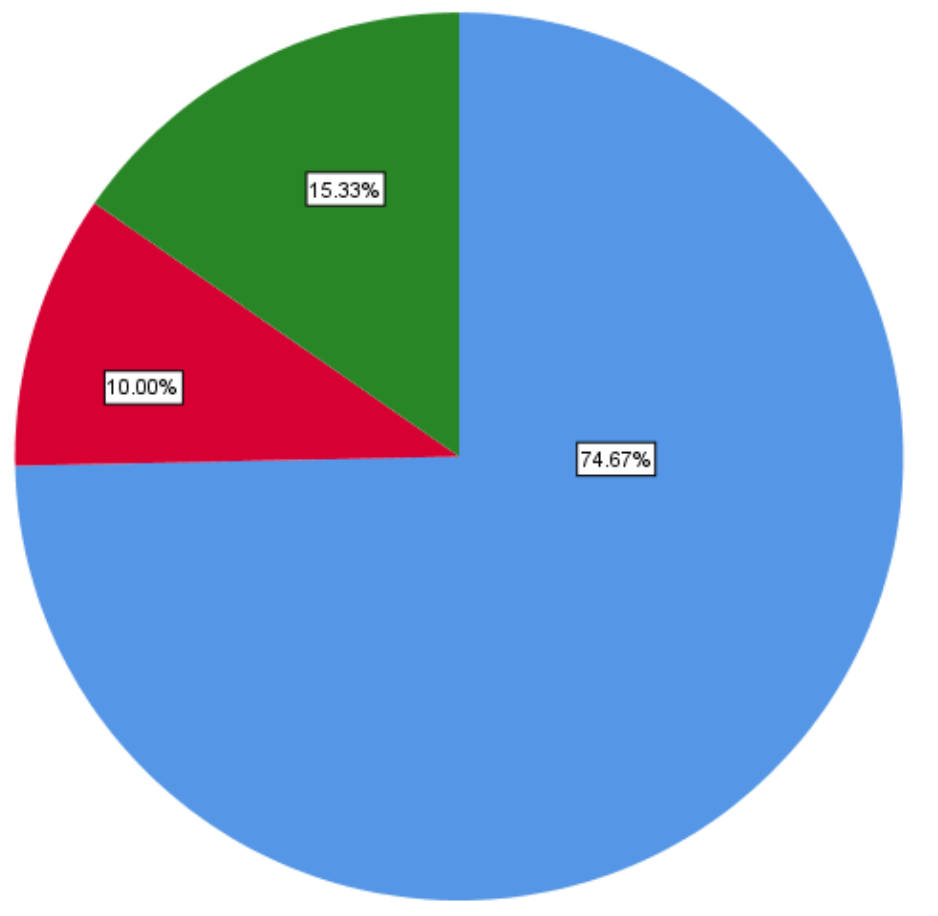

Time of Publication

Less Than One Year

1 Less Than 2 Years

More Than 2 Years 
FIGURE SEVEN. PIE CHART SHOWING PERCENTAGES OF NEWS CLASSIFICATION IN NEWS MEDIA

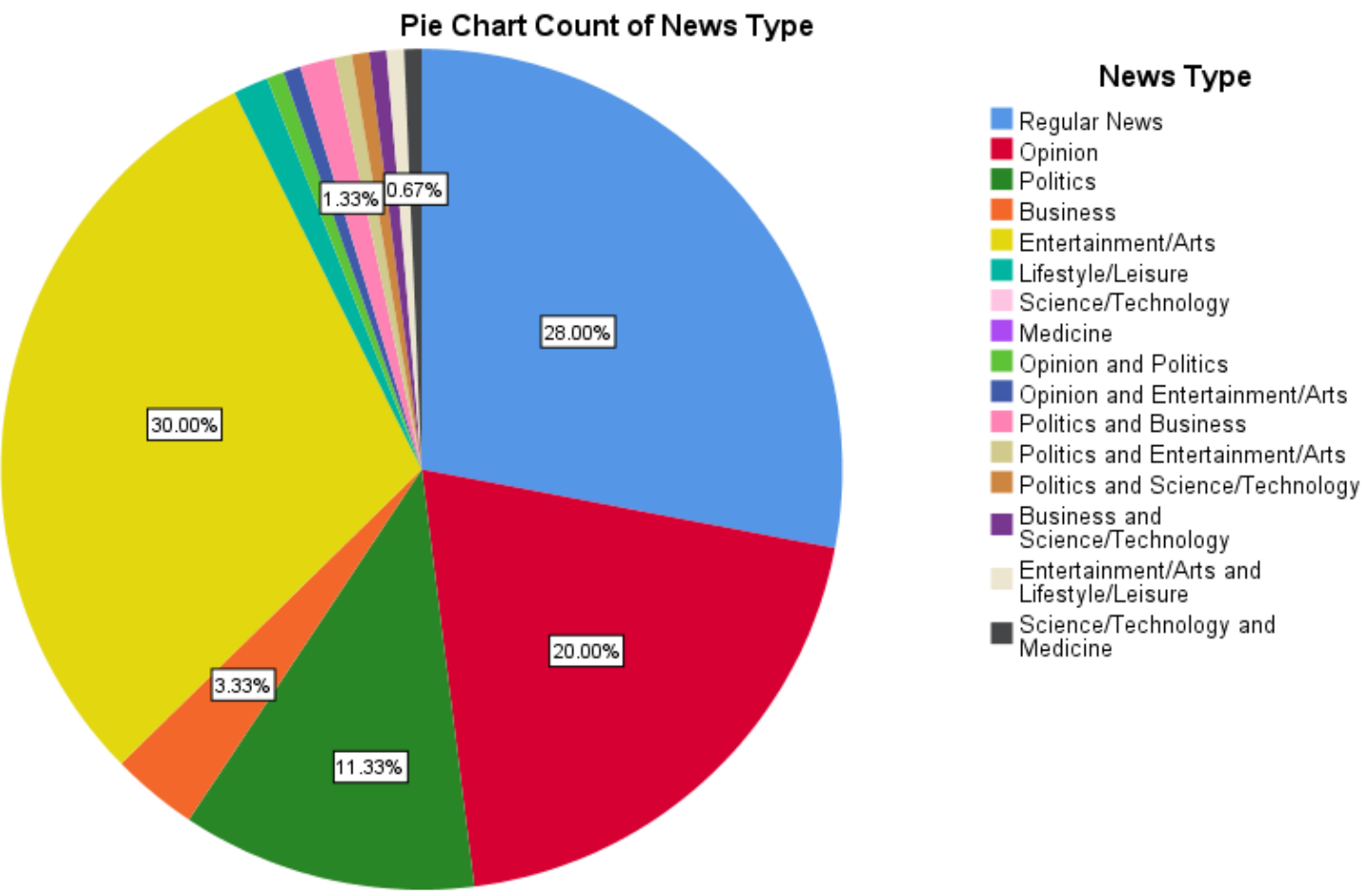

FIGURE EIGHT. PIE CHART SHOWING PERCENTAGES OF VISUALS IN NEWS MEDIA

Pie Chart Count of Visuals

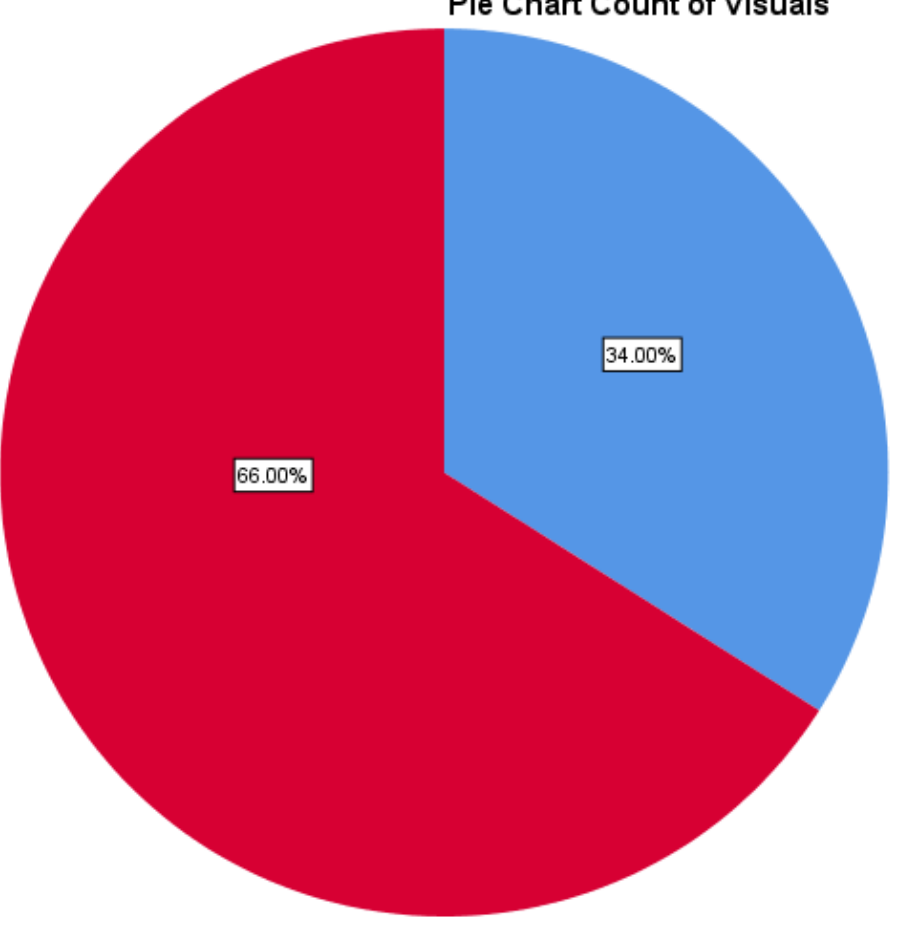

\section{Visuals}

- Visuals Not Included

- Visuals Included 
FIGURE NINE. PIE CHART SHOWING PERCENTAGES OF TYPES OF VISUALS IN NEWS $M E D I A$

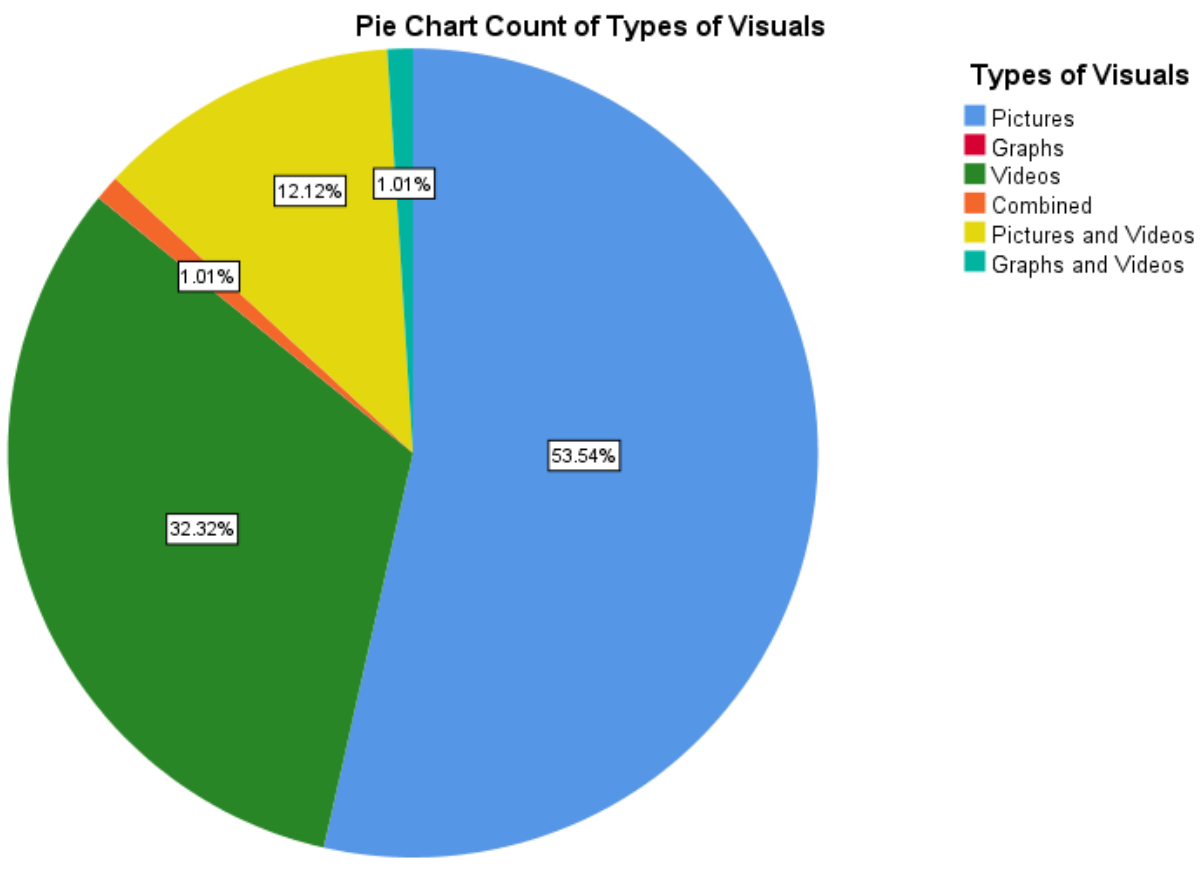

FIGURE TEN. PIE CHART SHOWING PERCENTAGES OF KNOWN AUTHOR IN NEWS $M E D I A$

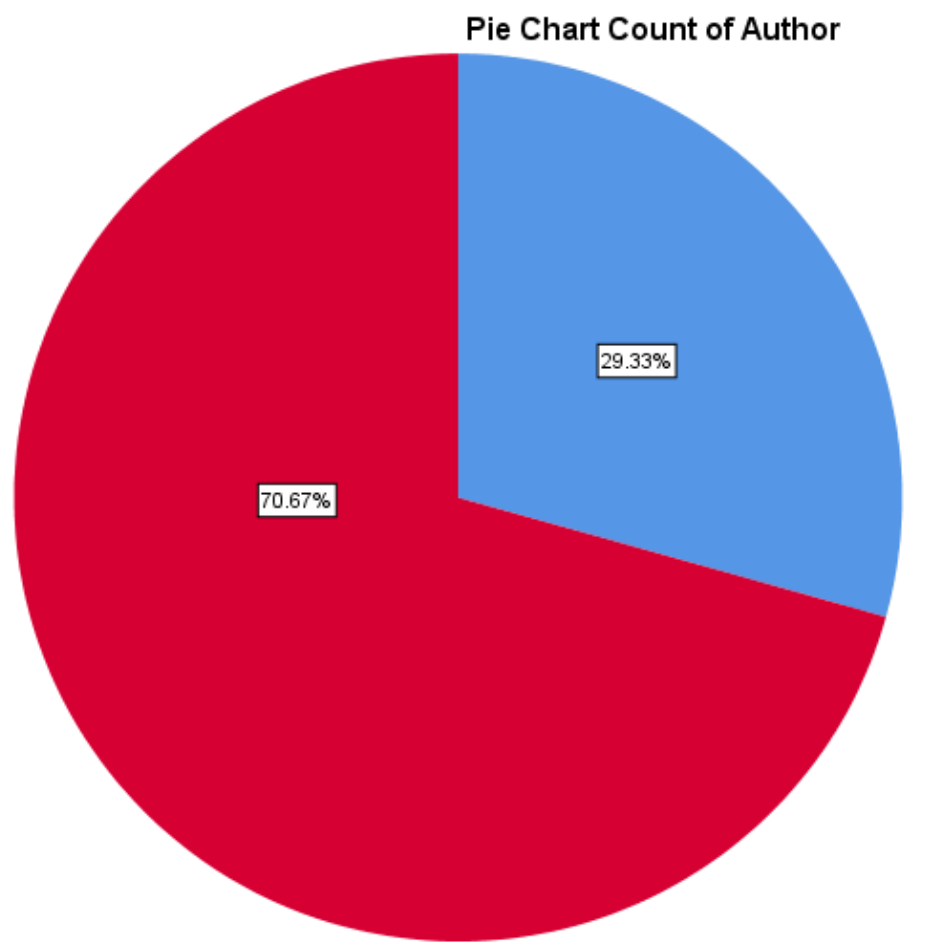


FIGURE ELEVEN. PIE CHART SHOWING PERCENTAGES OF GENDER OF AUTHOR IN NEWS MEDIA

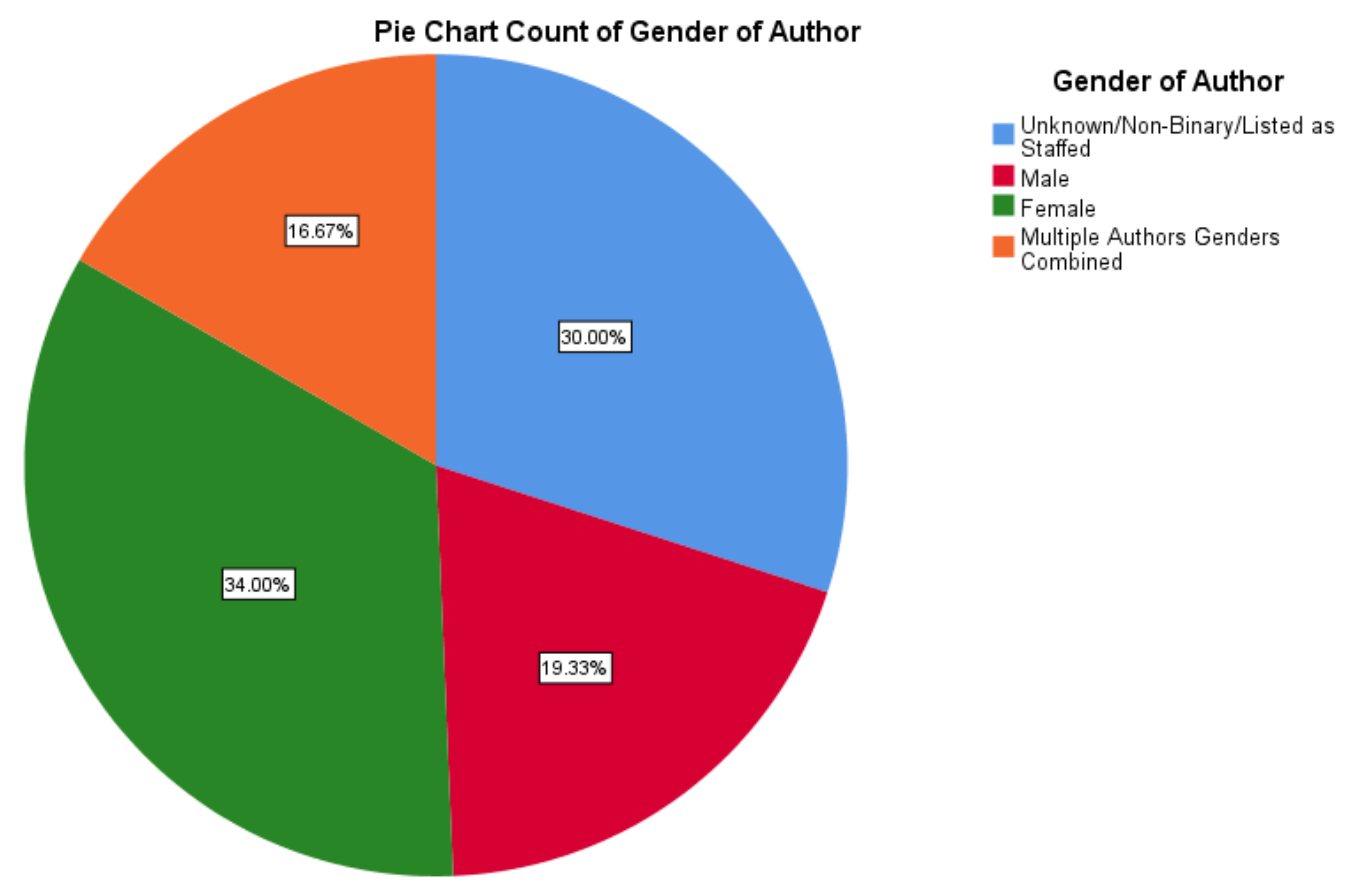

FIGURE TWELVE. PIE CHART SHOWING PERCENTAGES OF RACE OF AUTHOR IN NEWS $M E D I A$

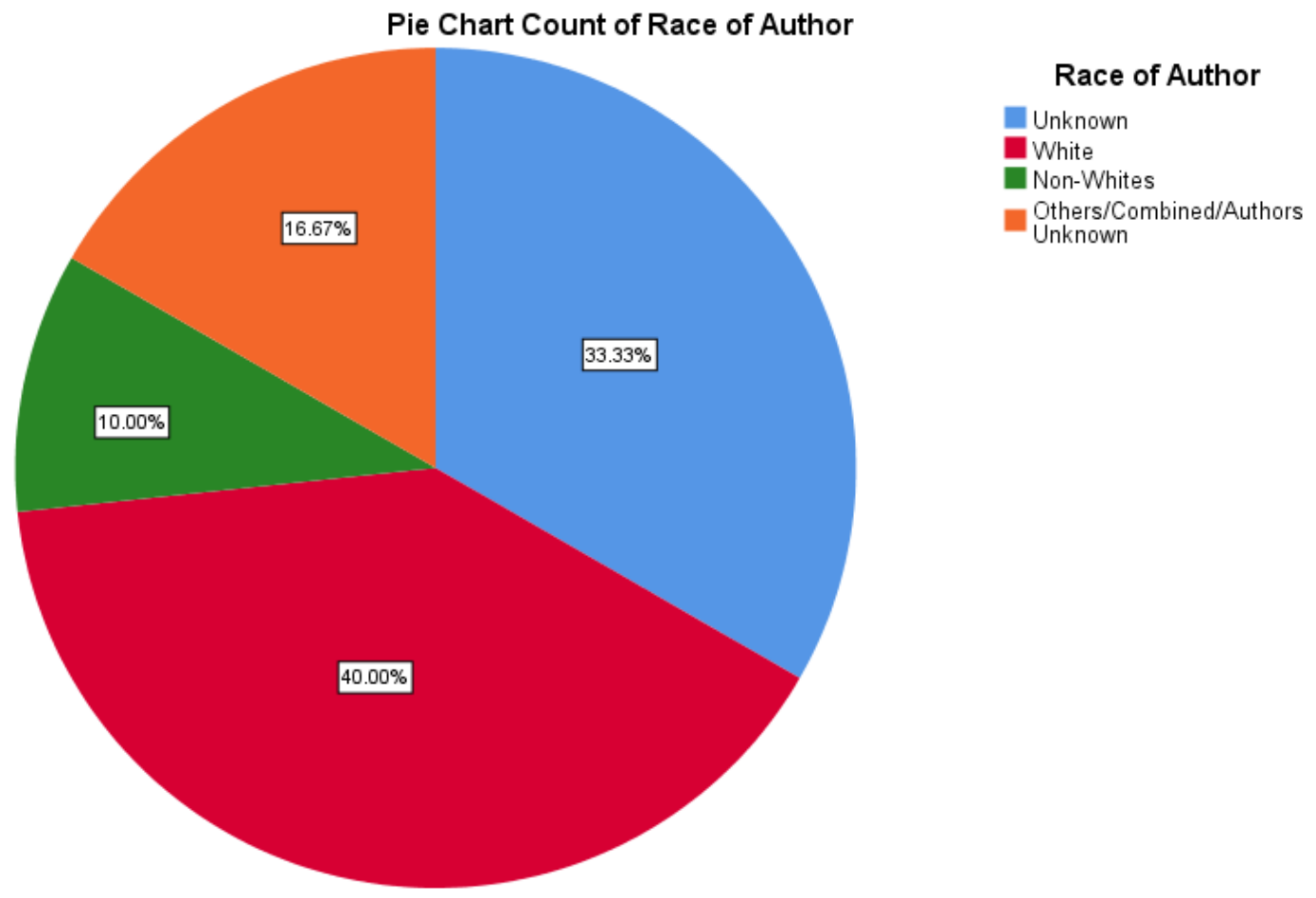


FIGURE THIRTEEN. HISTOGRAM GRAPH SHOWING NUMBER OF OFFICIALS AND CELEBRITIES

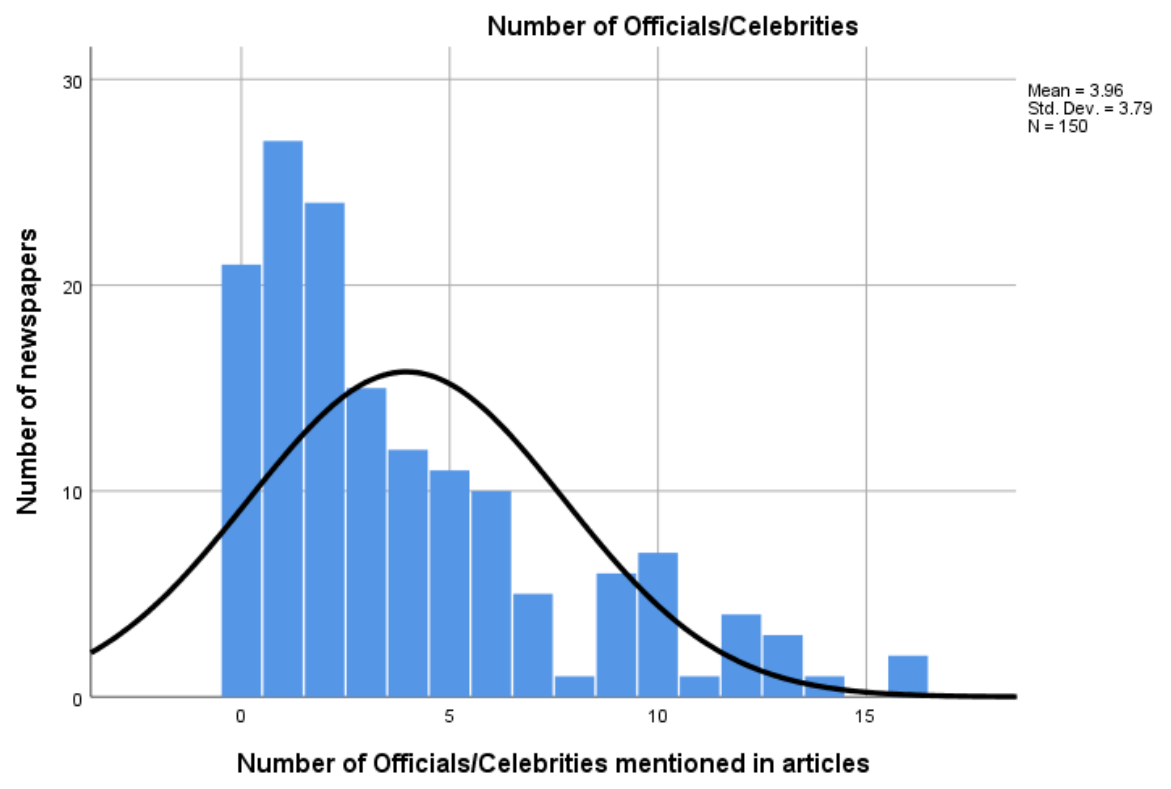

FIGURE FOURTEEN. HISTOGRAM OF NUMBER OF ORDINARY PEOPLE IN NEWS $M E D I A$

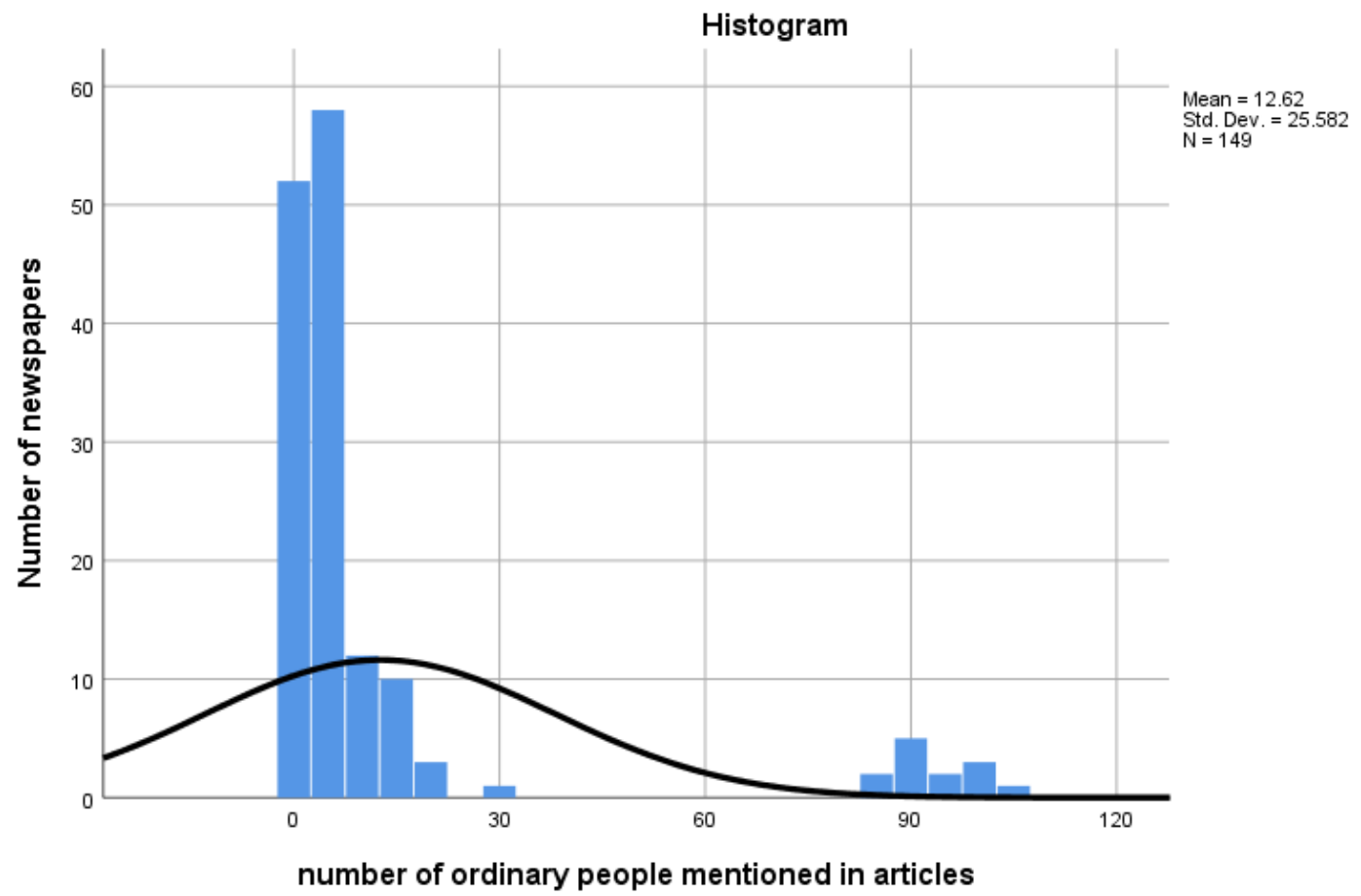


FIGURE FIFTEEN. HISTOGRAM OF NUMBER OF IDENTIFIABLE PERPETRATORS IN NEWS MEDIA

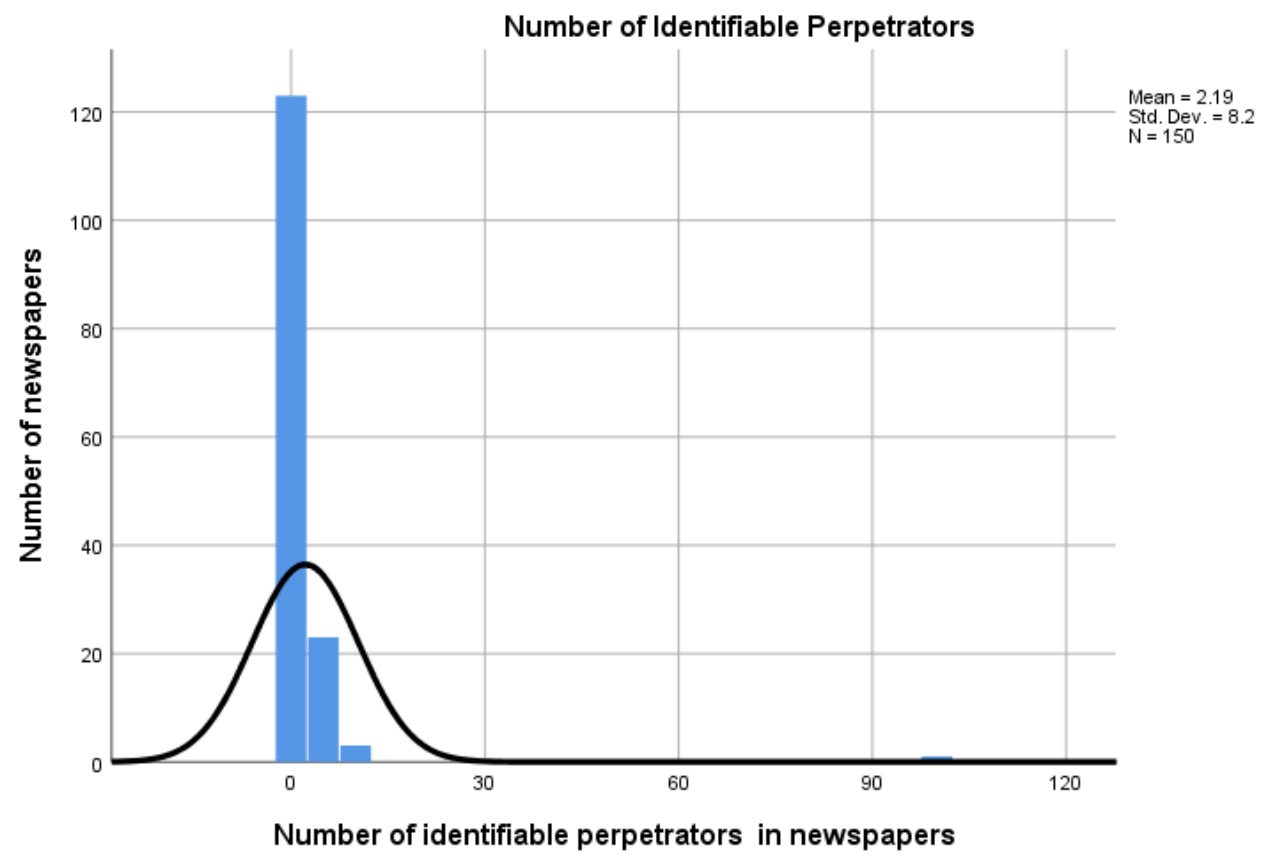

FIGURE SIXTEEN. HISTOGRAM OF NUMBER OF IDENTIFIABLE SURVIVORS IN NEWS $M E D I A$

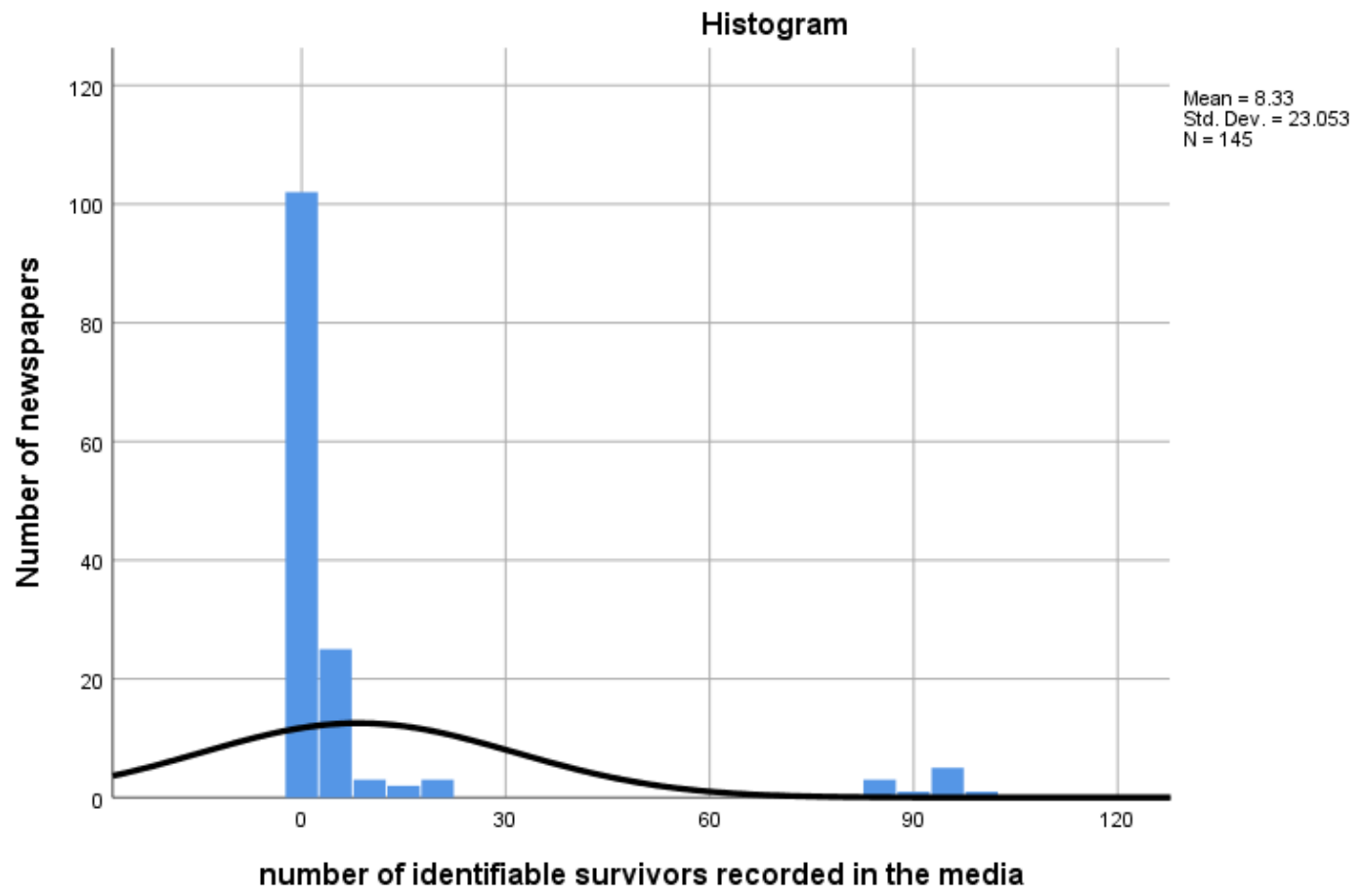


FIGURE SEVENTEEN. PIE CHART SHOWING PERCENTAGES OF MALE PERPETRATORS IN NEWS MEDIA

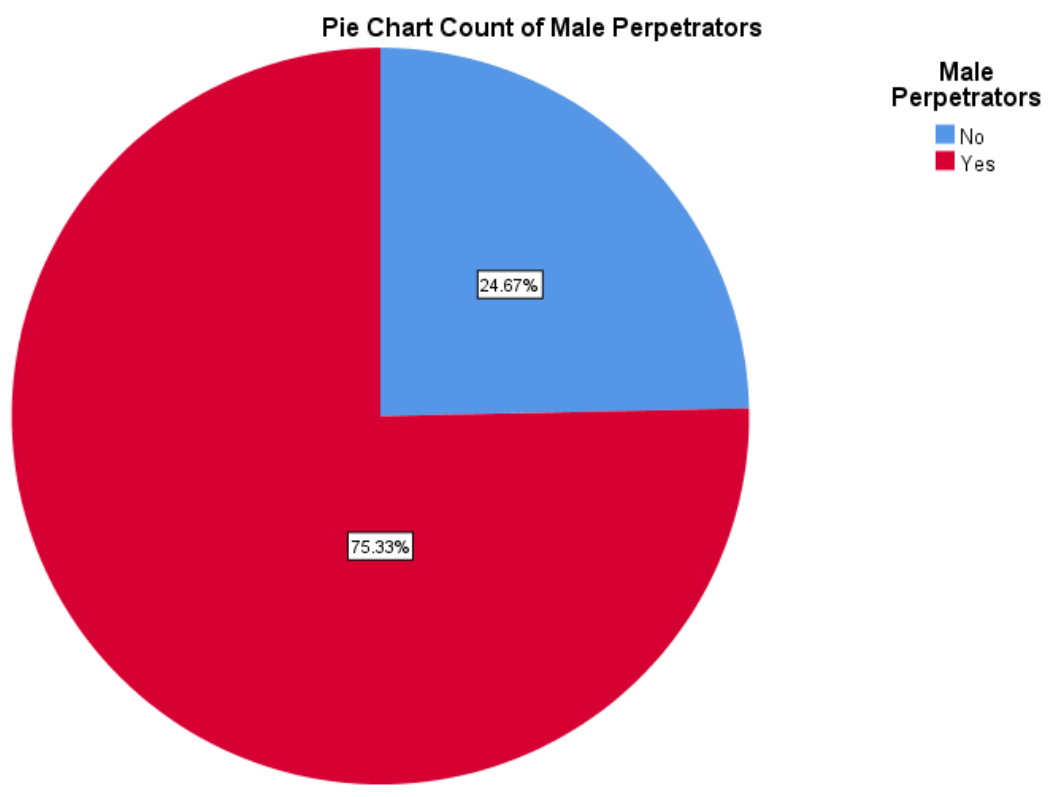

FIGURE EIGHTEEN. PIE CHART SHOWING PERCENTAGES OF FEMALE PERPETRATORS IN NEWS MEDIA

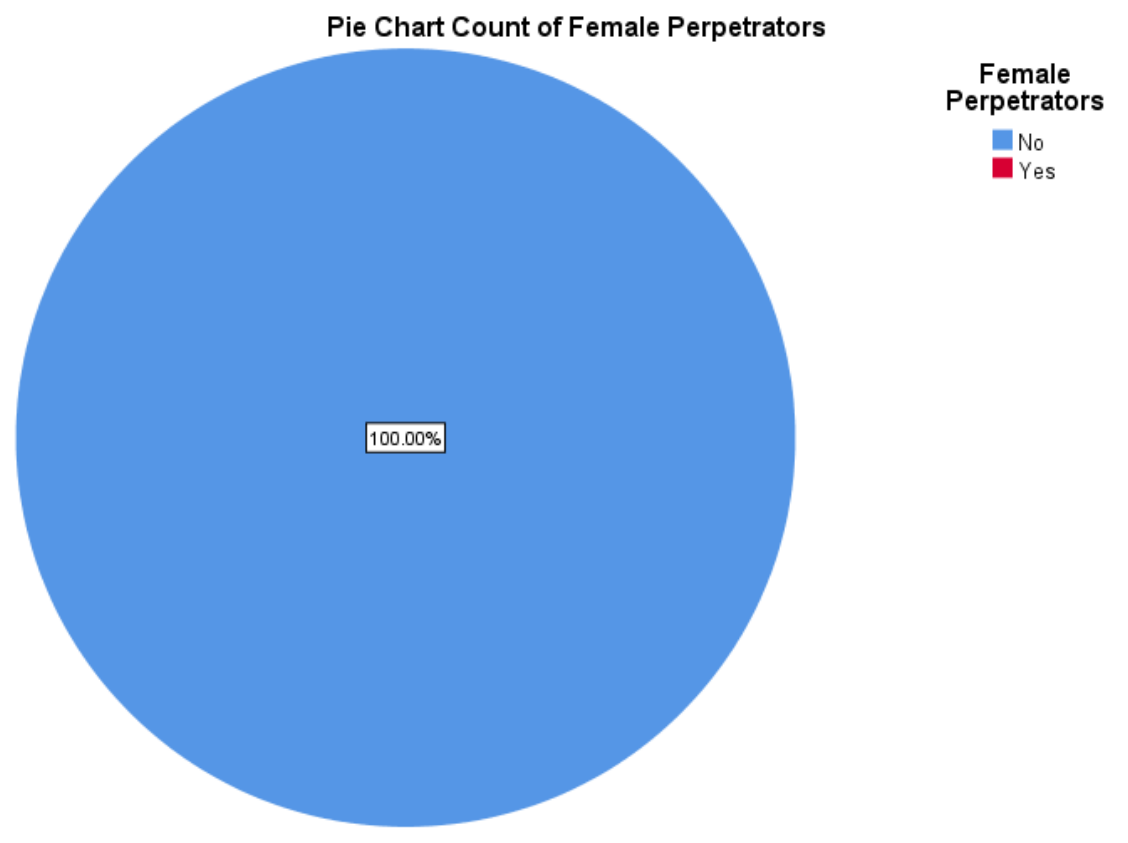


FIGURE NINETEEN. PIE CHART SHOWING PERCENTAGES OF MALE TARGETSSURVIVORS/VICTIMS IN NEWS MEDIA

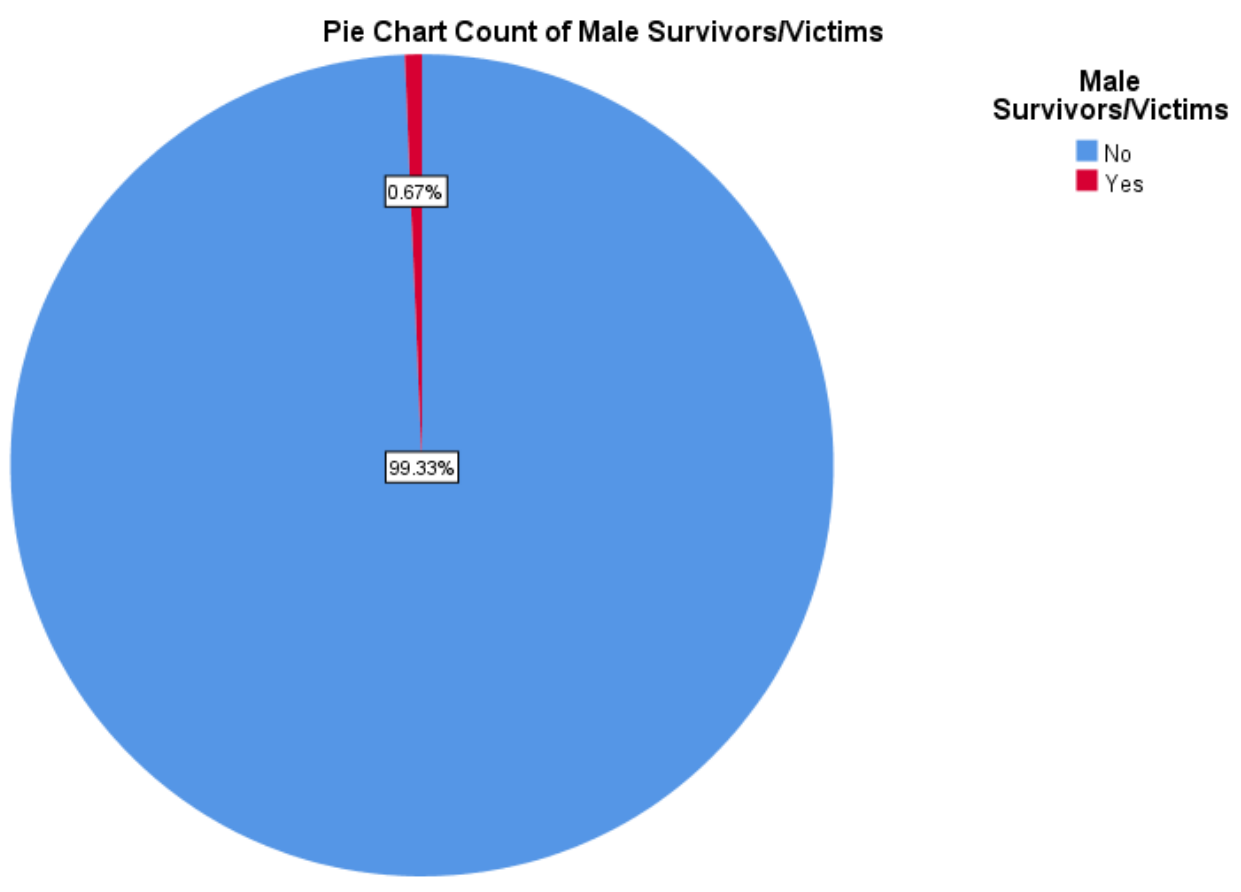

FIGURE TWENTY. PIE CHART SHOWING PERCENTAGES OF FEMALE TARGETSSURVIVORS/VICTIMS IN NEWS MEDIA

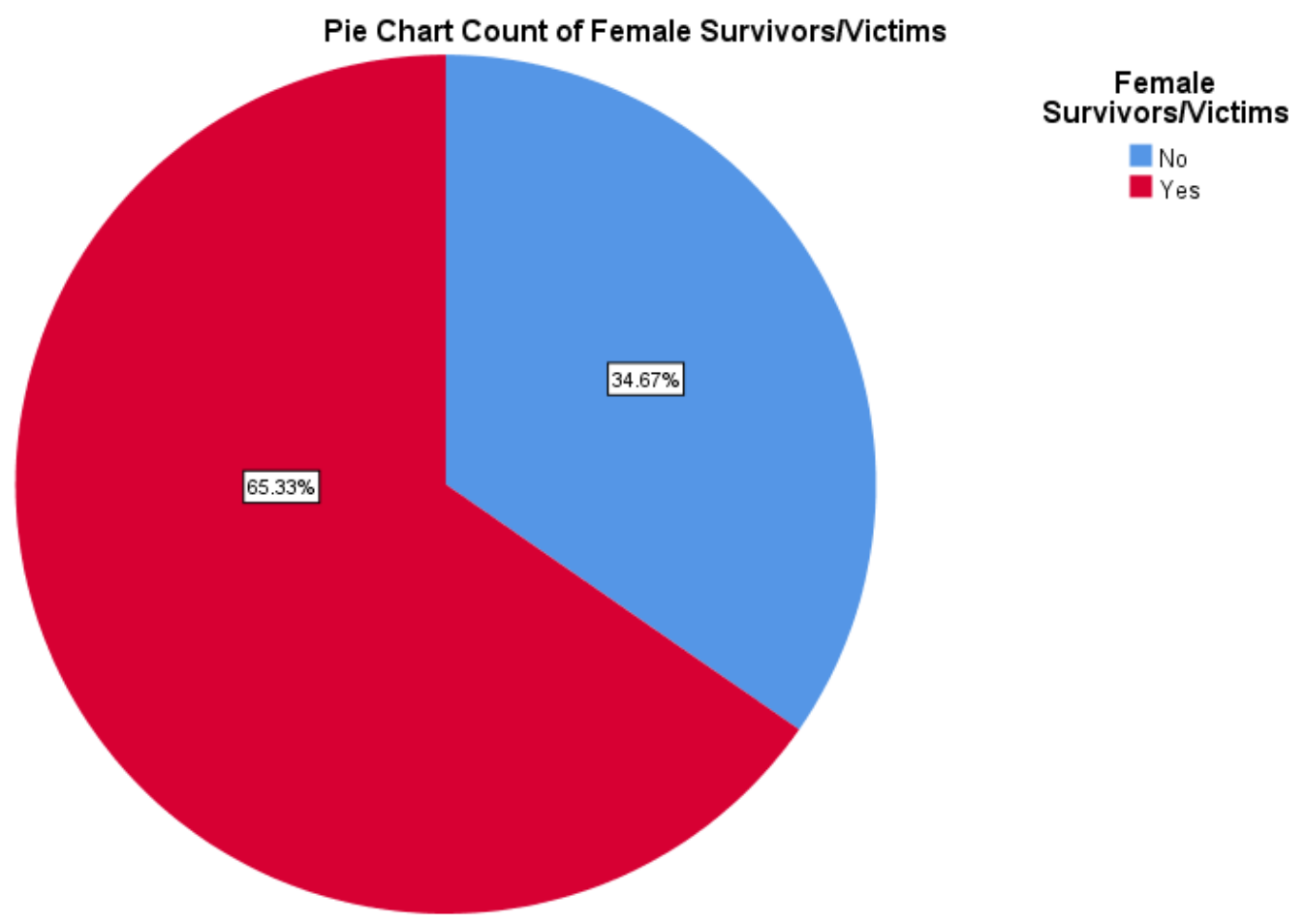


FIGURE TWENTY-ONE. PIE CHART SHOWING PERCENTAGES OF INCLUDES MINORS AS VICTIMS IN NEWS MEDIA

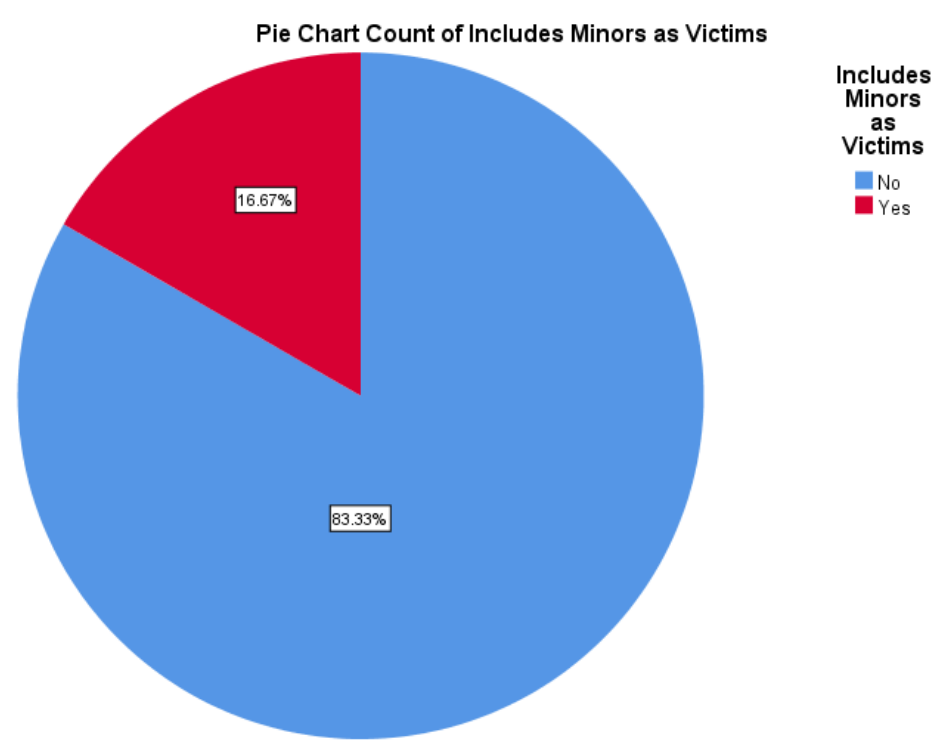

FIGURE TWENTY-TWO. PIE CHART SHOWING PERCENTAGES OF INCLUDES MINORS AS PERPETRATORS IN NEWS MEDIA

Pie Chart Count of Includes Minors as Perpetrators

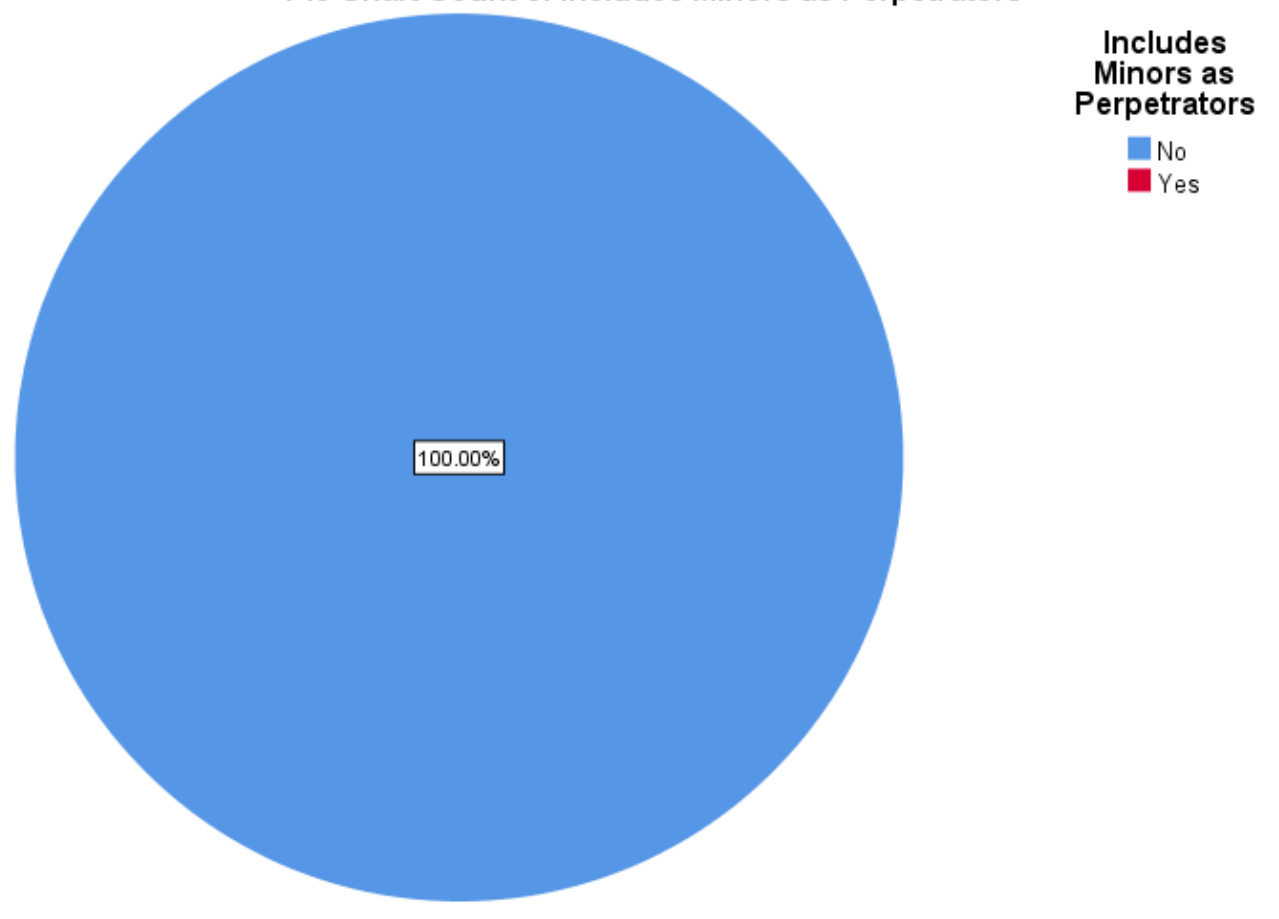


FIGURE TWENTY-THREE. PIE CHART SHOWING PERCENTAGES OF TYPES OF OVERALL VICTIMIZATION IN NEWS MEDIA

Pie Chart Count of Type of Victimization Recoded

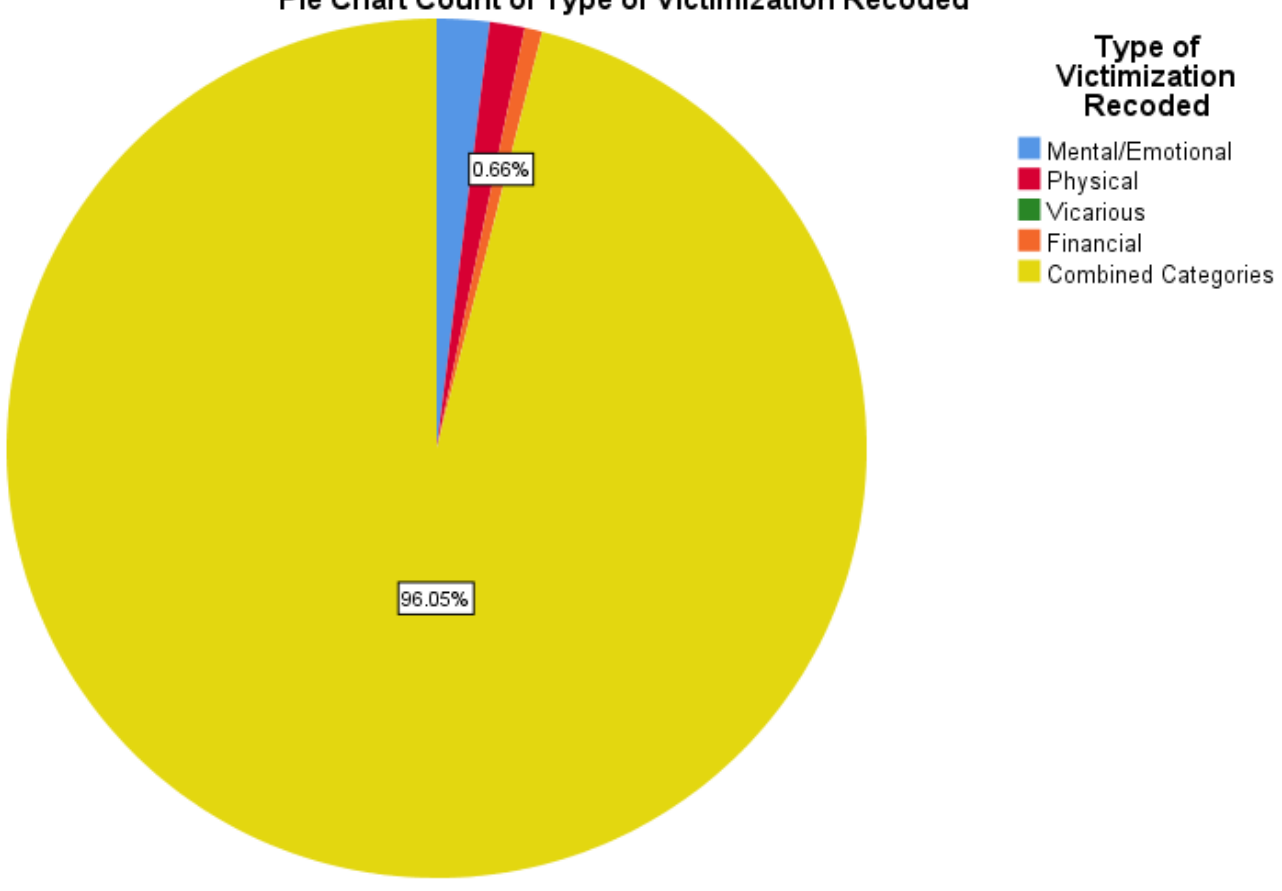

FIGURE TWENTY-FOUR. PIE CHART SHOWING PERCENTAGES OF TYPES OF SEXUAL VICTIMIZATION IN NEWS MEDIA

Pie Chart Count of Type of Sexual Victimization

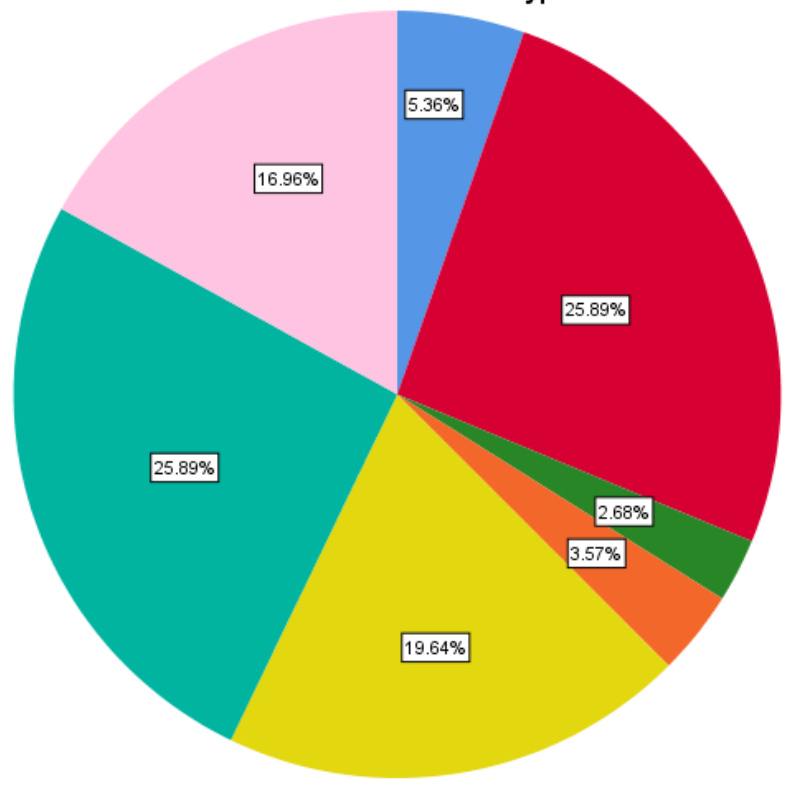

Type of Sexual

Victimization

Sexual Harassment/Non-

hysical

Sexual Assault

Rape

Gender Discrimination/Sexism

- Sexual Harassment/Non-

Physical and Sexual Assault

- Sexual Assault and Rape

Sexual Harassment/Non-

Physical and Sexual Assault

and Rape 
FIGURE TWENTY-FIVE. SHOWING PERCENTAGES OF LEGAL STATUS OF CASE IN NEWS MEDIA

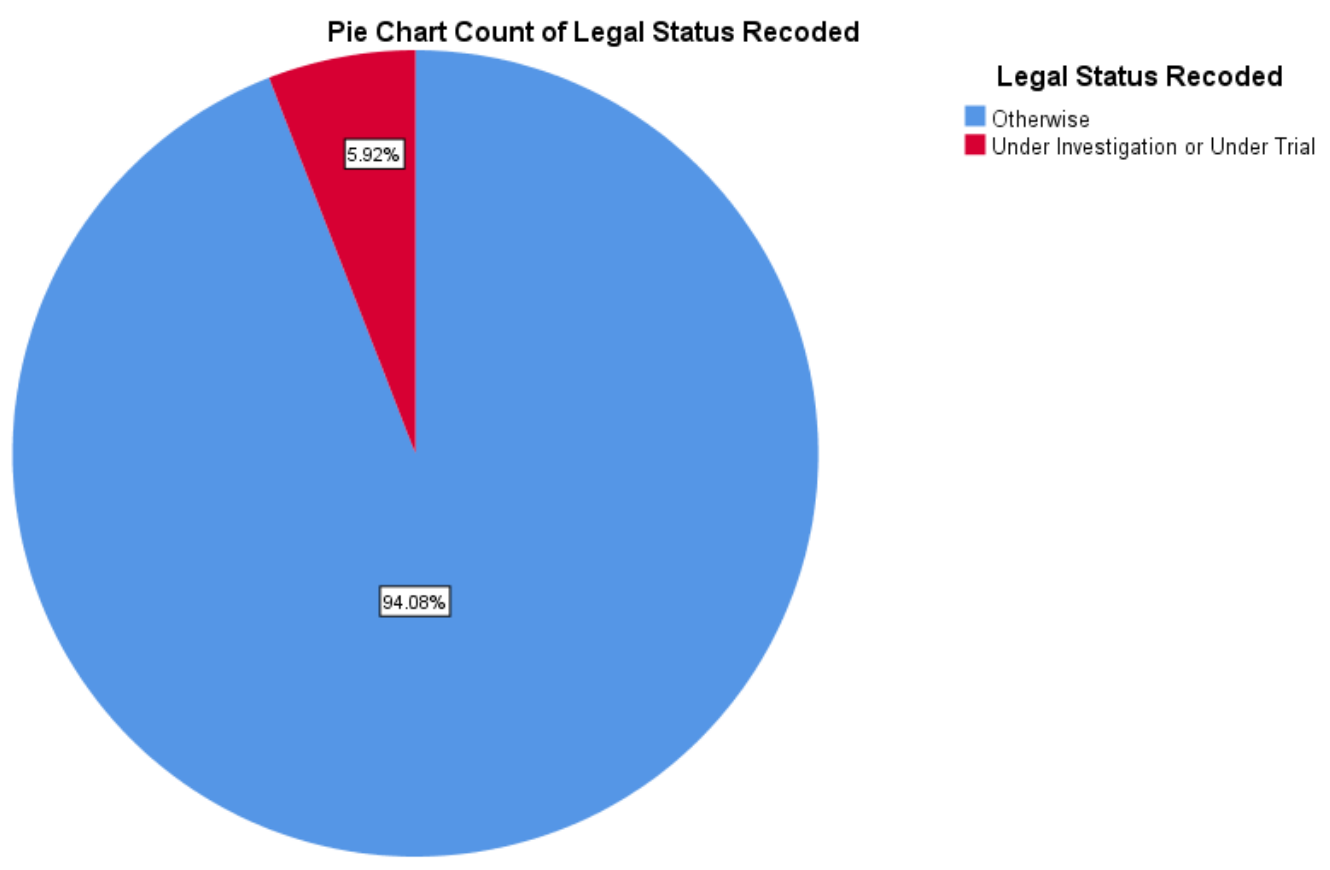

FIGURE TWENTY-SIX. PIE CHART SHOWING PERCENTAGES OF TREATMENT OF NEWS MEDIA

Pie Chart Count of Treatment of News for Length, Importance, Etc

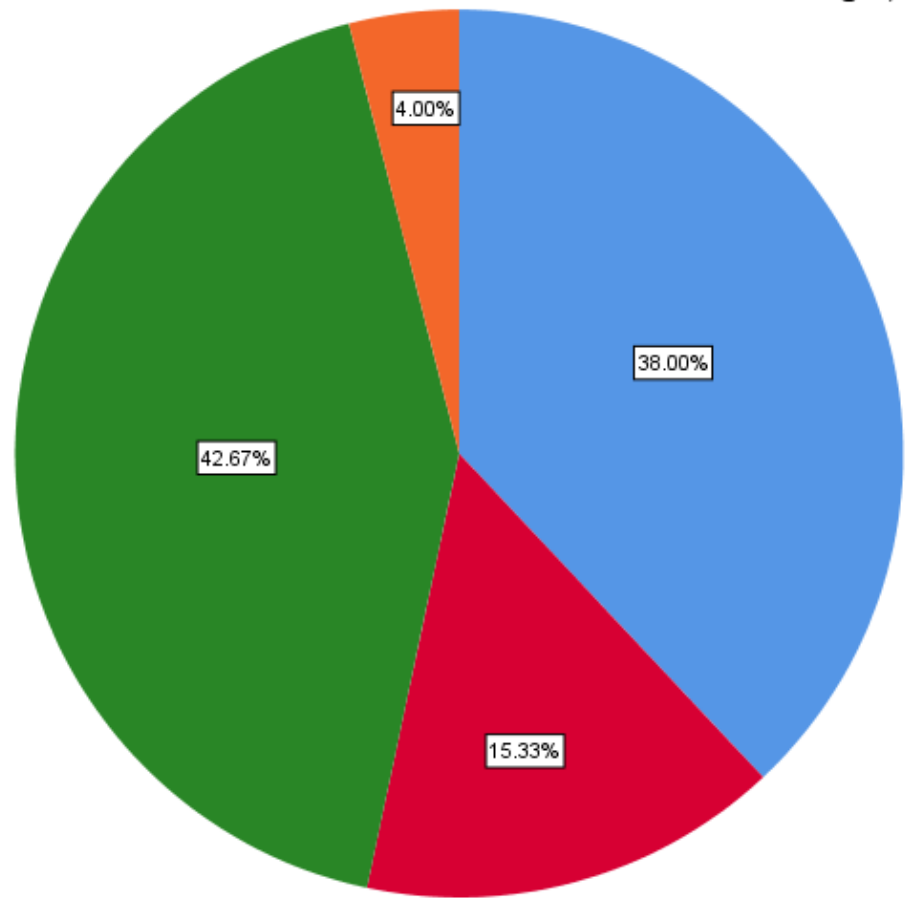

Treatment of News for Length, Importance, Etc

News

- Feature

Commentary/Criticism

ather 
FIGURE TWENTY-SEVEN. PIE CHART SHOWING PERCENTAGES OF TONE OF COMMENTARY WITH NEWS MEDIA

Pie Chart Count of Tone of Commentary

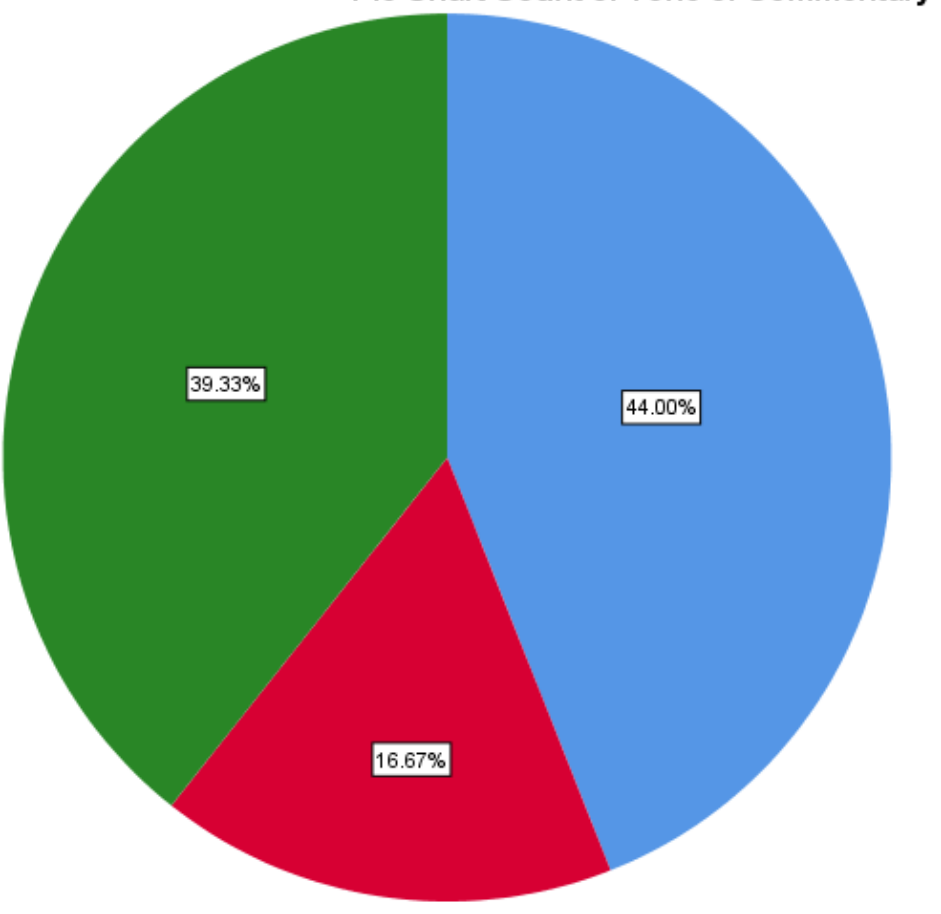

Tone of Commentary

Negative/Critical

- Positive/Non-Critical

Neutral 


\section{APPENDIX C. POPULATION PYRAMID SUMMARIZING CROSS TABULATIONS BETWEEN SELECT INDEPENDENT VARIABLE AND TONE OF COMMENTARY}

FIGURE ONE: TONE OF COMMENTARY AND GENDER OF AUTHOR

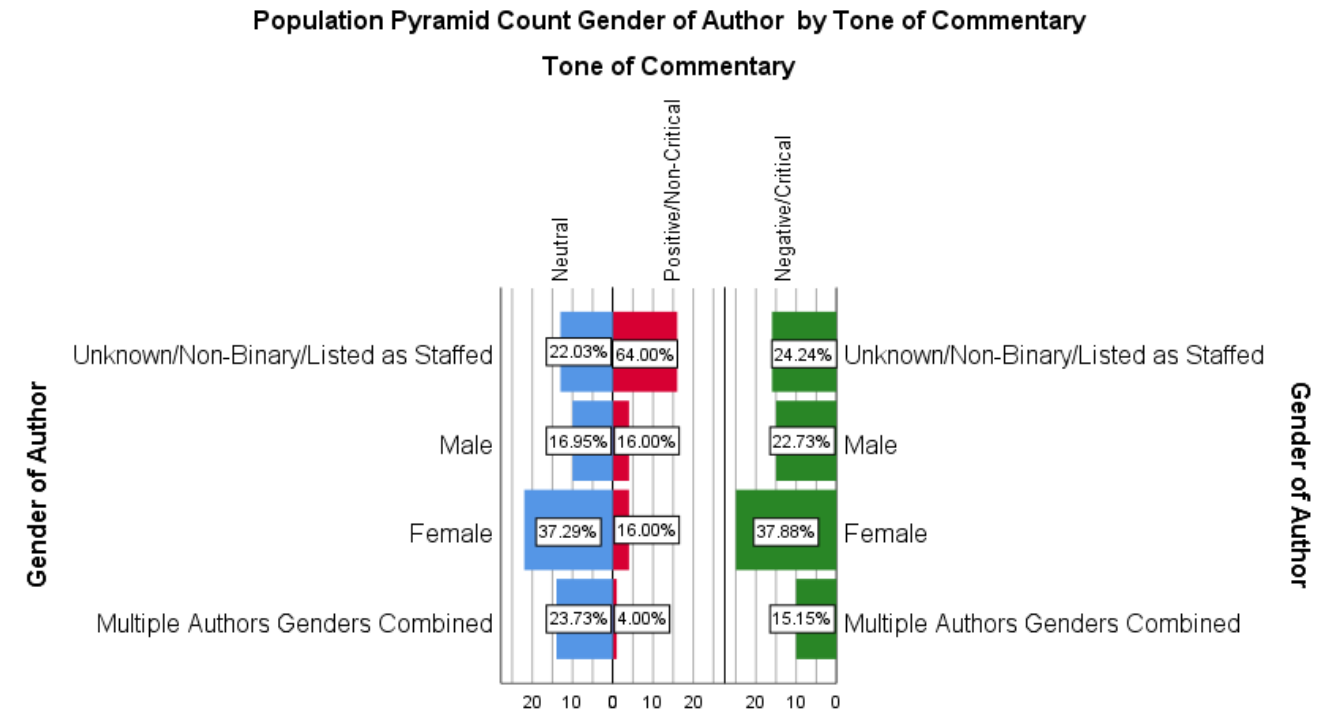

FIGURE TWO: TONE OF COMMENTARY AND SOURCE OF PUBLICATION

Population Pyramid Count Source of Publication by Tone of Commentary Tone of Commentary

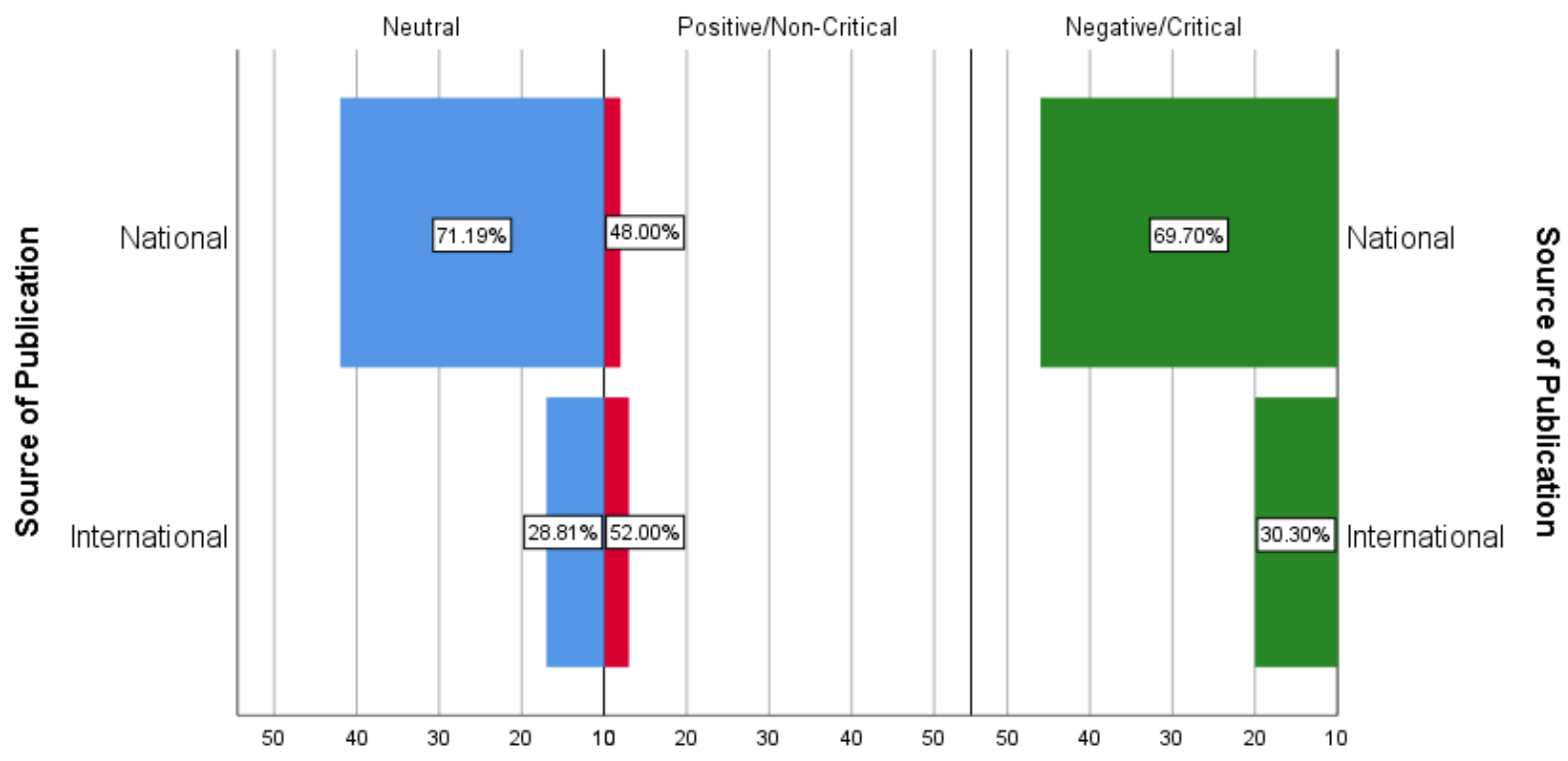


FIGURE THREE: TONE OF COMMENTARY AND REGION OF PUBLICATION (NATIONAL)

Population Pyramid Count Region of Publication (National) by Tone of Commentary Tone of Commentary

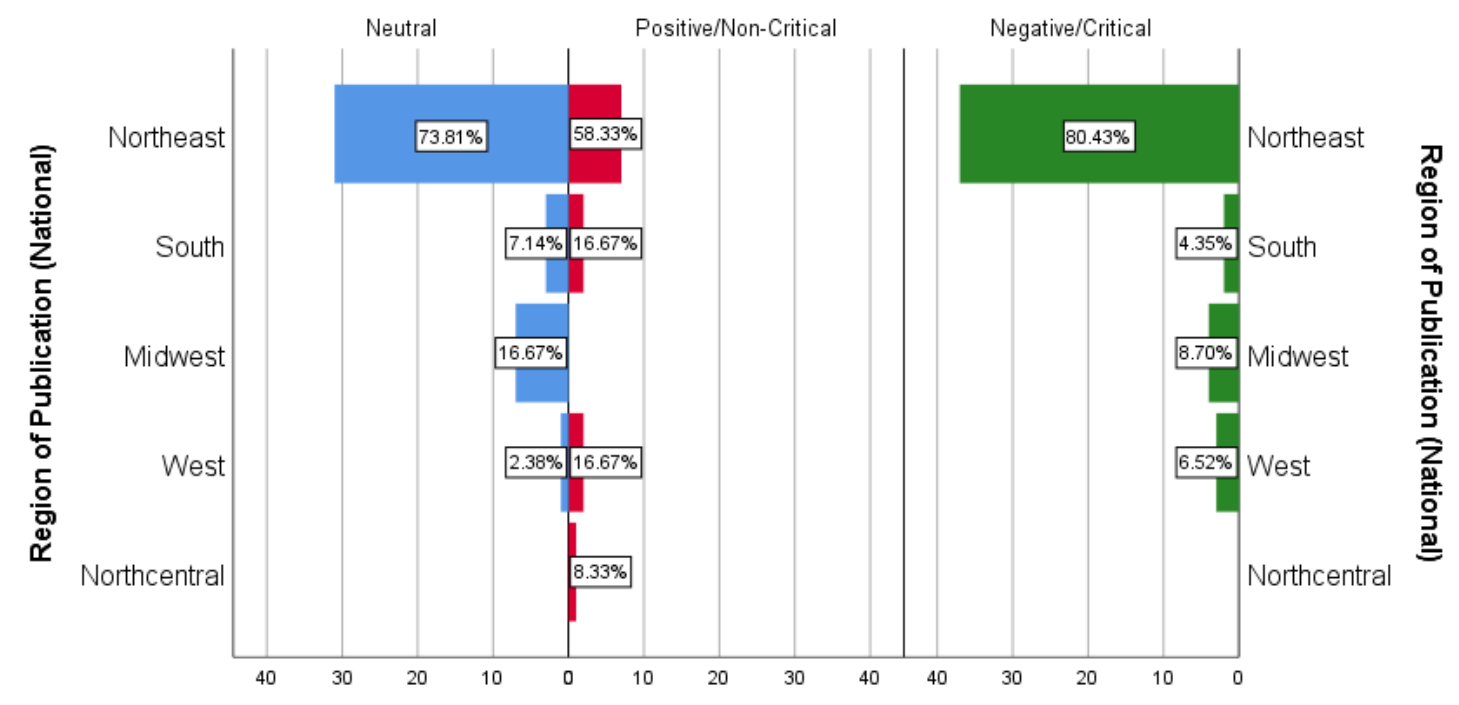

FIGURE FOUR. TONE OF COMMENTARY AND TIME OF PUBLICATION

Population Pyramid Count Time of Publication by Tone of Commentary Tone of Commentary

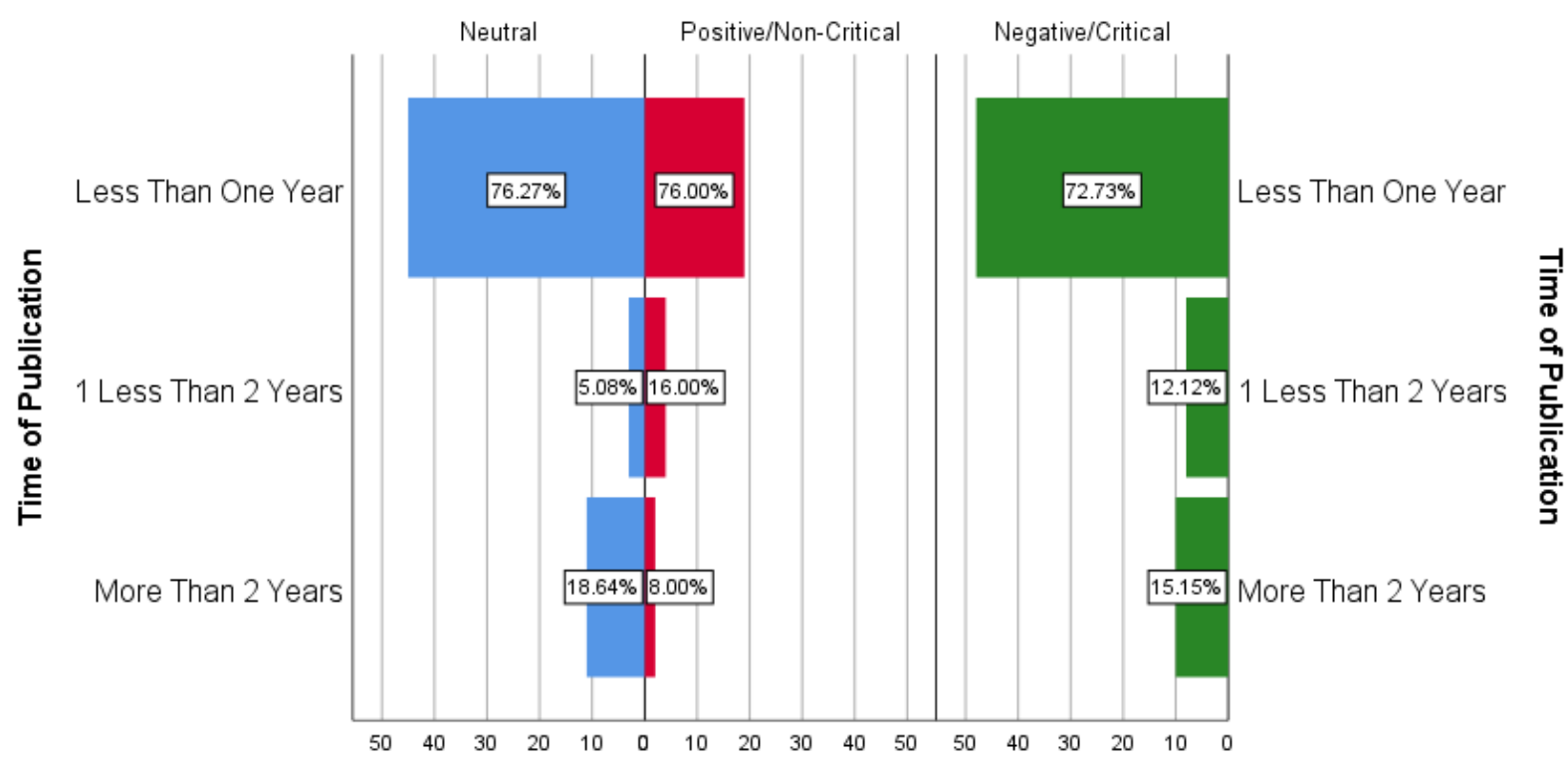


FIGURE FIVE: TONE OF COMMENTARY * NUMBER OF OFFICIALS AND CELEBRITIES RECODED

Population Pyramid Count Number of Officials and Celebrities Recoded by Tone of Commentary Tone of Commentary

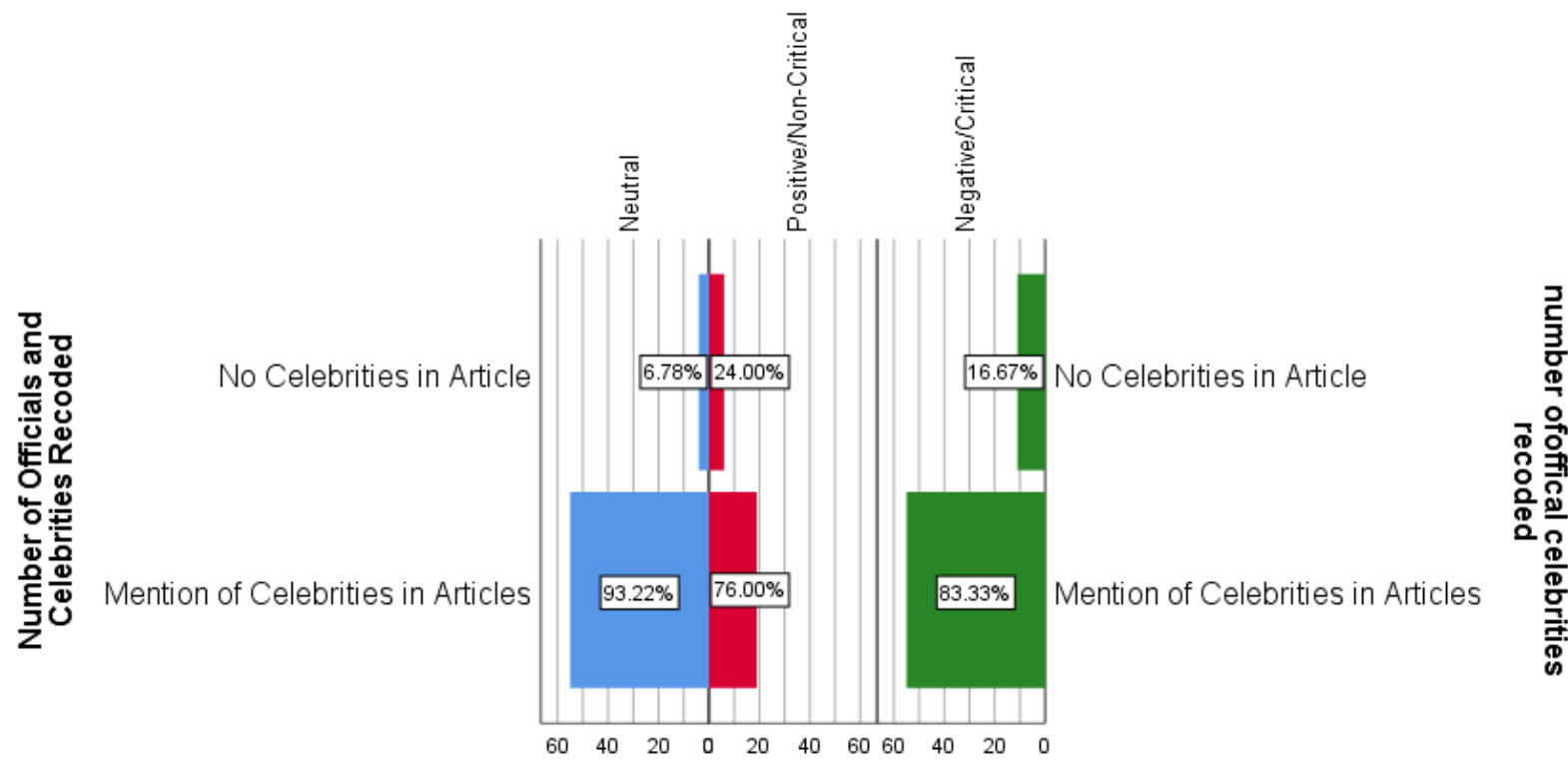

FIGURE SIX: TONE OF COMMENTARY AND OVERALL VICTIMIZATION

Population Pyramid Count Type of Overall Victimization Recoded by Tone of Commentary Tone of Commentary

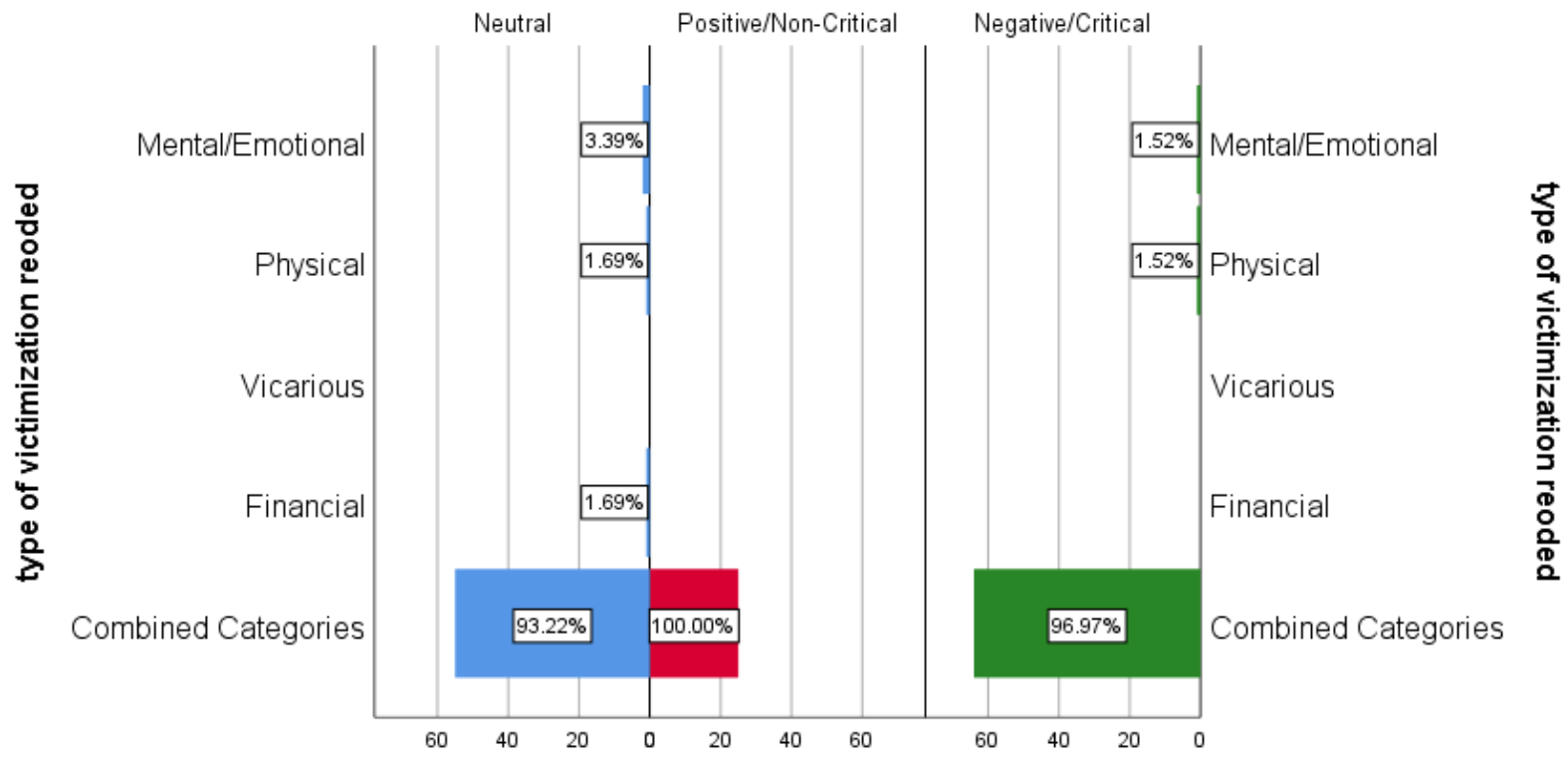


Figure Seven : TONE OF COMMENTARY AND LEGAL STATUS OF CASES

Population Pyramid Count Legal Status Recoded by Tone of Commentary Tone of Commentary

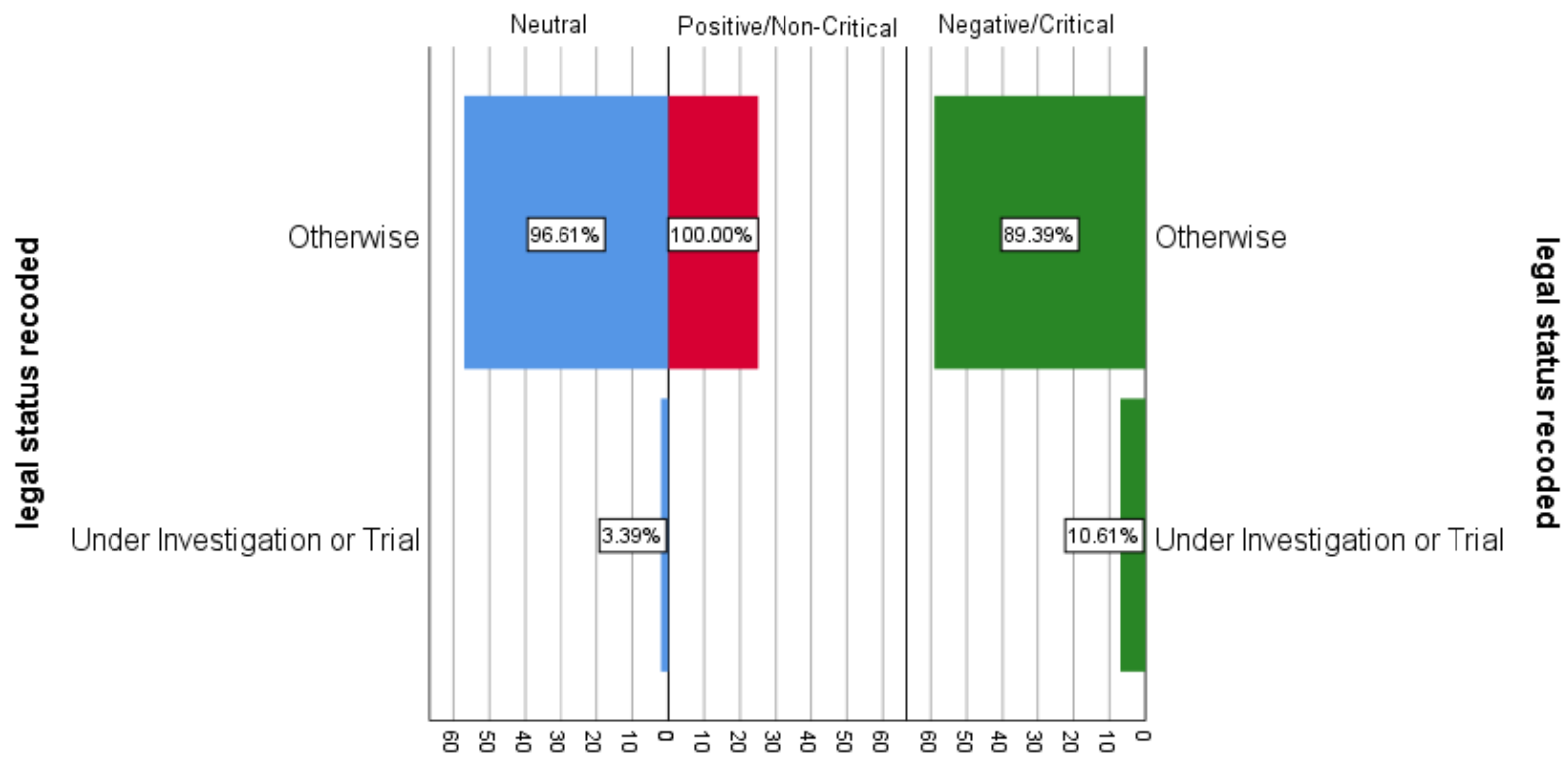




\section{APPENDIX D: MEANING UNITS}

1. Park Won-soon, Mayor of Seoul commits suicide after allegations

2. Park Won-soon, Mayor of Seoul fought for women's rights and commits suicide after allegations

3. Judge Dyson Heydon accused of harassment

4. Male student in Egypt accused by multiple women of assault and harassment

5. Documentary about Drew Dixon; racial and gender progress with movement

6. Books tackling harassment and abuse; young kids should read about

7. Movements can represent a possible successor to liberalism

8. \#BelieveAllWomen but not believe all women?

9. Feminists don't believe all women

10. Male-guilt rather than due process

11. Unsure whether to believe Tara Reade's accusations against Biden; stories are unclear and not solid

12. Joe Biden denies allegations

13. Is it credible to believe all women? Hypocrisy of both parties

14. Strict hierarchical code in Korea; more women are speaking out

15. What the "bad" men can do for the movement

16. Two of Trump's aides resign after allegations

17. Dylan Farrow, daughter of Woody Allen, accused him of sexual assault, Allen received no backlash

18. Bill Cosby survivor, Andrea Constand, says she forgives Cosby and is proud of movement

19. Catherine Deneueve denounces \#MeToo and \#BalanceTonPorc (Expose Your Pig)

20. French Movement Founder

21. Matt Damon said men are being lumped into one bucket

22. Attorney General of NY Eric Schneiderman resigned after allegations of abuse

23. Trial of Weinstein - Has the movement gone too far?

24. Weinstein does not think he did anything wrong

25. Women taking charge of own sexuality in fashion campaign; defining what it means during movement

26. Central Comedy show, The Man Show, poking fun of men's behavior would not go well now with the movement and allegations

27. How the movement can move towards policies and legal goals

28. Remove non-disclosure agreements

29. Movement needs to be more than just allegations

30. Stop violence of women in Mexico \#UnDiasInNosotras

31. Hachette Publishing cancels Woody Allen's book amidst allegations from daughter

32. How difficult it is to bring abusers to justice if they are wealthy and powerful

33. More must be done to help victims of abuse

34. Movement did not start and stop because of Weinstein; movement is just getting started

35. Weinstein was convicted but not all allegations were accepted

36. Fairness and Impartiality and Judicial System

37. Donald Trump called Weinstein case a victory for all women

38. Former Judge Stephen R. Reinhardt accused by women of harassment 
39. Survivors are fearful of speaking out

40. Inform of consent for pelvic exams

41. Enforcement in China is poor for allegations against men

42. Men in China using defamation lawsuits to counter claims of harassment and abuse

43. Hashtag \#MeToo and \#Woyeshi (Me Too) are banned on the Chinese internet; women are scrutinized for speaking out

44. Women in military remain in the shadows; movement steps up after woman is murdered while serving

45. Movement seeks vengeance

46. Cosby was deprived of due process

47. Cosby's wife said movement is racist

48. Garrison Keillor published book amidst allegations about him

49. Is movement inspired by vindictiveness?

50. Is movement turning into a partisan political weapon?

51. No victory for women, this mocks them

52. Repeal or extend statute of limitations

53. Behaviors needs to be recognized

54. Requirement for workplace harassment training

55. Weinstein is "totally confused" by movement and what he did, says he helped advance women's careers

56. Sexism in the workplace, gender discrimination at work

57. University of Illinois professor Jay Kesan receives paid leave after allegations

58. NY prior "bad act" law is outdated and unreasonable

59. Is Weinstein a target for the movement?

60. Weinstein used charm and power to prey on women; lawyers appealing verdict

61. Some laws have been interpreted, applied, and ignored

62. "Whisper Networks" women warning other women about predatory abusive men; scared to speak up

63. NJ campuses report rising rates of sexual abuse because of movement?

64. Halftime show exploitative and pornographic

65. Move message: no longer have to suffer in silence

66. Kobe Bryant accused of rape before movement; case was settled

67. Jane Garvey praised for speaking about women's rights

68. Parliament member, Charlie Elphicke sexual assault allegation finally brought to justice

69. Biden says "Believe Women"

70. Tara Reade wants Biden to withdraw from election

71. McDonald's settles $\$ 500$ million lawsuit against sexual harassment allegations with workers

72. Black women struggle to talk about sexual violence

73. Michael Bloomberg wants to release three NDA's from his company

74. Miss America pageants reforming organization in the midst of movement

75. Whether \#MeToo's impact equals change

76. Christmas song controversial following movement

77. Surviving R. Kelly documentary

78. Movie about abuse in Hollywood, power, money, NDA's

79. Dolly Parton first ever successful female singer-songwriter 
80. Rose McGowan says Michael Jackson was a bad man and complex

81. Movement makes Asian men think about how to treat women

82. Challenging Disney stereotypes

83. Bollywood Actor, Alok Nath, accused of rape

84. Movement hitting India

85. Violent crimes on railways

86. Teens talk about sexual assault

87. Not all men are bad; actress, Joanna Lumley, is worried all men are seen as bad

88. Movement is becoming global

89. South Korean women now speaking out against abuse

90. What is considered normal behavior? Bad date or assault? 


\section{APPENDIX E: CONDENSED MEANING UNITS}

1. \#MeToo Movement

2. \#BelieveAllWomen

3. \#BalanceTonPorc (Expose Your Pig)

4. \#UnDiasInNosotras

5. \#Woyeshi (Me Too)

6. Violence

7. Statute of Limitations

8. Due Process

9. Vindictiveness

10. Partisan Political Weapon

11. Workplace Harassment Training

12. Victory

13. "Bad Act" Law in NY

14. Appeal

15. Whisper Networks

16. Power

17. Money

18. Guilty

19. Innocent

20. Behaviors

21. Political Leaders

22. Wealthy Elite

23. Race

24. Gender

25. Internet

26. Fairness

27. Impartiality

28. Judicial System

29. Vengeance

30. Racist

31. Election

32. Sexism

33. Gender Discrimination

34. Title IX

35. Defamation

36. Harvey Weinstein

37. Verdict

38. Non-Disclosure Agreements

39. Joe Biden

40. Donald Trump

41. Tara Reade

42. Bill Cosby

43. Hypocrisy

44. Restorative Justice 
45. Sexual Assault

46. Sexual Harassment

47. Sexual Abuse

48. Rape

49. Male

50. Female

51. Author

52. Survivors

53. Perpetrators

54. Celebrity

55. Non-Celebrity

56. Type of Story

57. Allegations

58. Victim-Blaming

59. Women's Rights

60. Lawsuit

61. Equality

62. Respect

63. Stereotypes

64. Politics

65. Silence Breakers

66. Legal Intervention

67. Victims

68. Andrea Constand

69. Dylan Farrow

70. Tarana Burke

71. Rose McGowan

72. Ashley Judd

73. Asia Argento

74. Mhairi Morrison

75. Drew Dixon

76. Women in Military

77. Former President of Costa Rica Oscar Arias Sanchez

78. Garrison Keillor

79. Brett Kavanaugh

80. University of Illinois Professor Jay Kesan

81. Kobe Bryant

82. Charlie Elphicke

83. R. Kelly

84. Michael Jackson

85. Roy S. Moore (Alabama State Senate)

86. Rob Porter (Staff Secretary)

87. David Sorensen (Speechwriter)

88. Alok Nath (Bollywood Actor)

89. Miriam "Mimi" Haylei

90. Sandra Muller (French founder of \#BalanceTonPorc) 
91. Adele Haenel (High-profile actress to speak out in France)

92. Women Around the World: China, North/South Korea, France, India, Egypt, etc

93. Types of Movement

94. Laws \& Policies

95. Types of Sexual Violence

96. Woody Allen

97. Mayor of Seoul Park Won-soon

98. Judge Dyson Heydon

99. Former NY Attorney General Eric Schneiderman

100. Judge Stephen R. Reinhardt

101. Perpetrators

102. Accused

103. Victimization

104. Mental Victimization

105. Physical Victimization

106. Emotional Victimization

107. Characteristics

108. Traits

109. Class

110. Ethnicity

111. \#TimesUp

112. \#NiUnaMenos (Not One Less) Latin America

113. Molestation

114. School and Campus Policies

115. Strict Hierarchical Codes

116. Credibility

117. Male-Guilt

118. Law Enforcement

119. Bullying

120. Toxic Masculinity

121. Newspaper Articles

122. Style

123. Opinion

124. World

125. Books

126. Media

127. International

128. National

129. Movies

130. Business

131. Health

132. Entertainment \& Arts

133. Videos 


\section{APPENDIX F: CODES WITH SUB-CODES AND SUBSEQUENT THEMES}

- Types of Overall Victimization

- Mental/Emotional Victimization

- Physical Victimization

- Vicarious Victimization

- Financial Victimization

- Theme: The human impact of the \#MeToo movement

- Characteristics \& Traits

- Race

- Gender

- Class

- Ethnicity

- Theme: Survivors, Accused, and Perpetrators have different characteristics and traits

- Types of Movements

- \#MeToo Movement

- \#BelieveAllWomen

- \#BalanceTonPorc (Expose Your Pig)

- \#UnDiasInNosotras (A Day Without Us)

- \#Woyeshi (MeToo)

- \#TimesUp

- \#NiUnaMenos (Not One Less) Latin America

- Theme: Combining social movements around the world

- Types of Sexual Violence/Victimization

- Sexual Assault

- Sexual Harassment

- Rape

- Gender Discrimination/Sexism

- Laws \& Policies

- Theme: Sexual violence and behaviors can vary

- Statute of Limitations

- School and Campus Policies

- Stereotypes

- Sexism

- Gender Discrimination

- Title IX

- NDA's (Non-Disclosure Agreements)

- Equality

- Defamation

- "Bad Act" Law in NY

- Judicial System

- Lawsuit

- Strict Hierarchical Codes and Regulations

- Theme: Laws and policies are being challenged in the midst of the movement 
- \#MeToo Movement

- Victim-Blaming

- Vindictiveness

- Victory

- Women's Rights

- Equality

- Credibility

- Racist

- Internet

- Allegations

- Verdict

- Innocent

- Guilty

- Appeal

- Hypocrisy

- Vengeance

- Partisan Political Weapon

- Male-Guilt

- Due Process

- Law Enforcement

- Bullying

- Toxic Masculinity

- Theme: Evolving definition of movement

- Type of Story

- Regular News

- Opinion

- Politics

- Business

- Entertainment/Arts

- Lifestyle/Leisure

- Science and Technology

- Medicine

- Author

- Newspaper Articles

- Male

- Female

- Style

- World

- Books

- Media

- Movies

- Health

- Videos

- International

- National

- Theme: The types of stories have been voiced and portrayed differently 
- Celebrities

- Perpetrators and Accused

- Donald Trump

- Joe Biden

- Harvey Weinstein

- Bill Cosby

- Woody Allen

- Mayor of Seoul Park Won-soon

- Judge Dyson Heydon

- Former NY Attorney General Eric Schneiderman

- Judge Stephen R. Reinhardt

- Former President of Costa Rica Oscar Arias Sanchez

- Garrison Keillor

- Brett Kavanaugh

- University of Illinois Professor Jay Kesan

- Kobe Bryant

- Charlie Elphicke

- R. Kelly

- Michael Jackson

- Roy S. Moore (Alabama State Senate)

- Rob Porter (Staff Secretary)

- David Sorensen (Speechwriter)

- Alok Nath (Bollywood Actor)

- Theme: Men who were accused of sexual violence (some have either dismissed or denied the allegations, others have been convicted)

- Survivors and Victims

- Andrea Constand

- Tara Reade

- Dylan Farrow

- Tarana Burke

- Rose McGowan

- Ashley Judd

- Asia Argento

- Miriam Haylei

- Sandra Muller (French founder of \#BalanceTonPorc)

- Adele Haenel (high-profile actress to speak out in France)

- Mhairi Morrison

- Drew Dixon

- Women in Military

- Women Around the World: China, North/South Korea, France, India - Theme: Women who came forth about their sexual abuse

- Whisper Networks and Silence Breakers
○ Power
- Money
- Politics 
- Theme: "Whisper networks" have been created to warn others about predatory abusive individuals

- Legal Intervention

- Restorative Justice

- Workplace Harassment Training

- Eliminate NDA's (Non-Disclosure Agreements)

- Extend or repeal Statute of Limitations

- Theme: Acts to recognize inappropriate behaviors 